
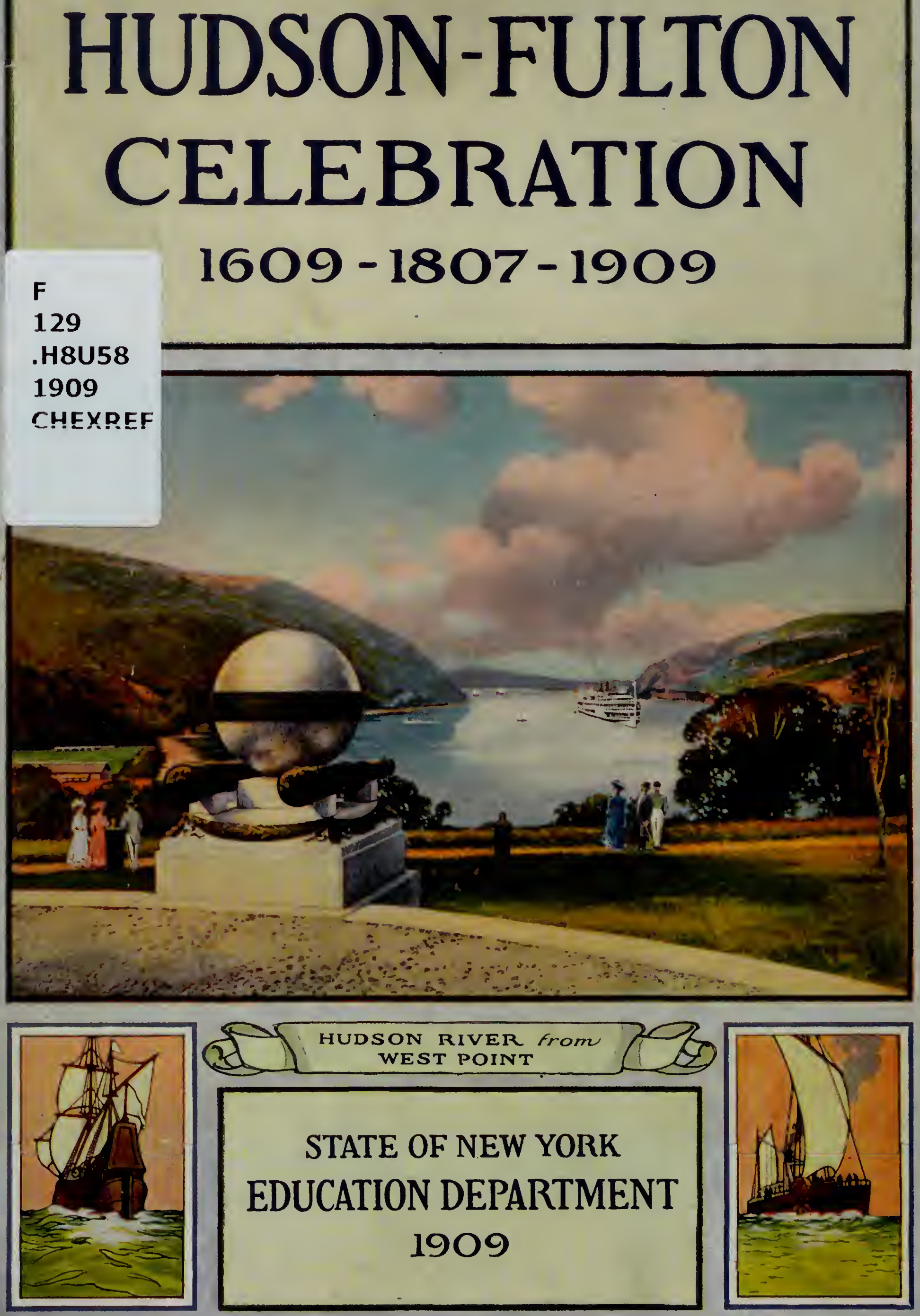


$$
10
$$




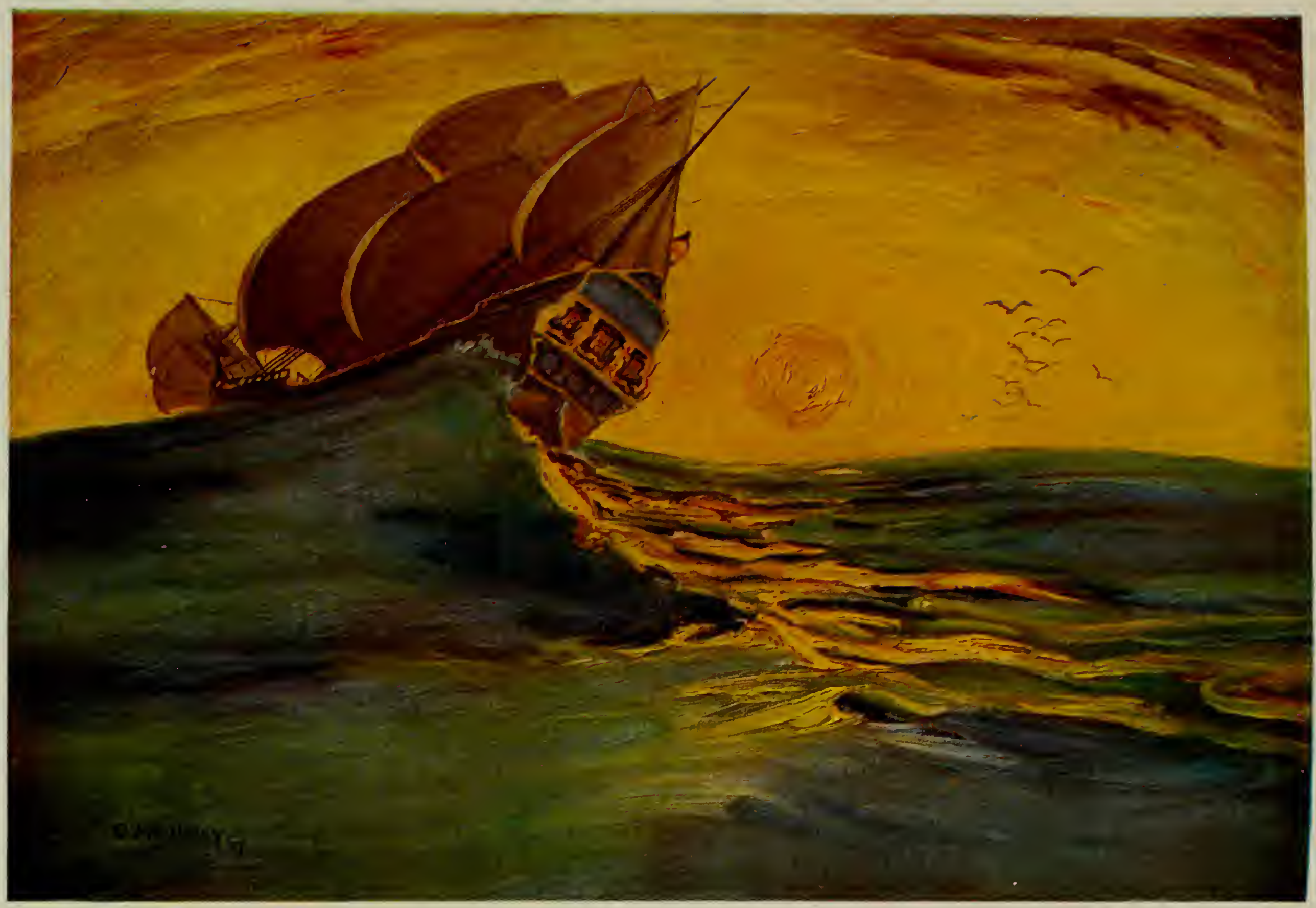

The Half Moon in quest of the Far East 


\title{
THE HUDSON-FULTON CELEBRATION
}

\section{BY THE COMMISSIONER OF EDUCATION}

\begin{abstract}
*
7 HE State of New York is arranging an elaborate celebration in honor of the Hudson river and of the great events associated with its waters and its shores. The celebra-
\end{abstract} tion will begin on the 25th of September, 1909, and continue at different points and with varying features to the 9th of October. Wednesday. September 29th, will be the Educational day of the celebration.

The time chosen is the three hundredth anniversary of the first exploration of the river by Captain Henry Hudson, in the little sailing ship "Half Moon," sent out by the good "people of Holland. It is a little more than a hundred years from the time when Robert Fulton, in the "Clermont," proved that steam power might be relied upon to propel boats.

The Hudson river has borne many names. Some of the Indians called it "Mah-i-can-i-tuk," which meant "the place of the Mohicans" ; and others, "Ca-ho-ha-ta-tea," or "river that flows from the mountains." The Dutch named it the "Mauritius" in honor of Prince Maurice, the great son and successor of William the Silent. The French called it "La Grande river," and the Spanish, the "River of the Mountains." The English more often gave it the name of the "North river" (the Delaware being the South river), and by that name it is frequently called now. But the popular sense of justice came to call it "Hudson's river," and that finally settled down to the "Hudson river." The common fairness has now been confirmed by many laws.

None of its great names has been too good for it. It is a splendid, deep, free-flowing stream. It is the outlet of great mountains and magnificent valleys. It has tides all the way to Albany. It is bordered by beautiful slopes and stately peaks; by the Palisades, a great stone wall fifteen miles in length; and by thrifty cities and splendid residences as well. In picturesqueness, in always changing, and quickly changing, views, it is hardly equaled by any other river in America, or in the world.

It is a river which has long been useful and dear to a great and prosperous civilization. Although Hudson sailed for the Dutch, he first made known his discovery to the English; and although the English king required him, an English subject, not to leave the English service again, the Dutch were the first to establish trading posts and 
settlements upon the Hudson river. The Dutch were a little people, but in some things they were greater than the largest. In manufactures and trade upon the seas, in fighting power, and in schools of all grades and kinds, they were then the foremost nation in the world. They had just had a forty years' war and had laid down a hundred thousand lives for liberty. It had made them the freest nation in the world. Of course, they brought their personal traits and their national feeling to the Hudson. For full fifty years those traits and feelings had their free opportunity in "New Amsterdam" and "New Netherland"; and of course they have a large share in the foundational history of the State of New York.

Just as Hudson was exploring, and Dutch settlers were beginning to locate upon the Hudson river, our Pilgrim forefathers were hunted out of England by religious bigotry. They were welcomed in Holland. A dozen years later they migrated to America, intending to settle upon the Hudson, but were landed upon the Massachusetts coast by reason of bad weather, or the captain's fraud. The Pilgrims and the Dutch had common feelings and cordial relations. Neither had any love for the king and the Royalists in England, who in 1664 sent an armed fleet and took possession of New Amsterdam and called it New York. In the meantime, twenty or thirty thousand English Puritans, and some Royalists, had settled in New England. A few had come over into New York. They were upright, religious, intolerant, autocratic, aggressive people. The English knew much, very much for their day, about human rights. They had fought for their rights within as well as without the kingdom. They had set limits to the power of the king. They brought "Magna Charta" and a good system of laws and of courts to America with them. They were divided among themselves, and had, the Royalists particularly, much friction with the Dutch. But by the time the English Puritans and the Dutch had combined their forces and overwhelmed the English government in the American War for Independence, and by the time they had forced the British armies to surrender, and had driven the Royalists or "Tories" out of the country, they were fused into a united people. They had learned to tolerate each other, and to tolerate other people also. They welcomed people from all the nations. Working together, they became generous-minded and made the great qualities of each even greater than they were before. Out of it all came the "Empire State" and other great states and the great Union of the states. 
All this and much more, in infinite detail, is associated with the valley of the Hudson river, and must be made much of in our celebration. There is not a point upon the river, not a stream or a valley that leads into it, not a peak that looks down upon it, that is without its legend and its story. War, with its horrors and its heroisms, has had a large part in it. Treason left its stain upon it. Learning, literature, the arts and sciences, agriculture, manufactures, banking, law, politics, statesmanship, have run as freely in the Hudson valley as the ever-flowing waters of the river.

The first school in the United States; the first federal Congress; the initial and the decisive battles of the Revolution; and the approval of the federal Constitution were in sight of it. The convention that framed the first state Constitution of New York was forced by the British army up the river from New York to White Plains, then to Harlem, then to Kingsbridge, then to Odell's in the Philipse Manor, then to Fishkill, then to Poughkeepsie, and then to Kingston, where, with the scales of justice in one hand and the drawn sword in the other, on Sunday, April 20, 1777, it completed its splendid work, only to have advancing war at once compel it to move again.

Let us think of what the names of Clinton, Tompkins, Yates, Woodhull, Gansevoort, Schuyler, Tallmadge, Root, Scott, Livingston, Duane, VanCortlandt, VanRensselaer, particularly Hamilton and Jay, and a host of others, signify in the early history of the Hudson: let us think of the teachers, and preachers, and scholars, and writers, who have wrought upon its shores: let us enter into the enlightened policy of the State which long ago made it the greatest highway of travel and commerce in the country, and let us have a share in the new purpose that such it shall remain forever.

The schools may do more than any other agencies to put red blood and a true spirit into the coming celebration. New York has never been very generously treated - it has sometimes been badly treated - by the professional writers of American history. Let us enter in no haphazard or half-hearted way into a great celebration which is being arranged to arouse a keener appreciation of the doings of our fathers. Let the pupils read much of the history which makes the Empire State so great. Let them write upon it. Let the exercises upon the 29th of September be public and popular, the worthy expression of a fine school system, and the vital inspiration of a yet greater State. 


\section{HENRY HUDSON'S QUEST}

(1609)

2

UT from the harbor of Amsterdam

The Half Moon turned her prow to sea;

The coast of Norway dropped behind,

Yet northward still kept she

Through the drifting fog and the driving snow,

Where never before man dared to go:

"O Pilot, shall we find the strait that leads to the Eastern sea?"

"A waste of ice before us lies - we must turn back," said he.

Westward they steered their tiny bark,

Westward through weary weeks they sped,

Till the cold gray strand of a stranger-land

Loomed through the mist ahead.

League after league they hugged the coast,

And their Captain never left his post:

"O Pilot, see you yet the strait that leads to the Eastern sea?"

"I see but the rocks and the barren shore; no strait is there," quoth he,

They sailed to the North - they sailed to the South -

And at last they rounded an arm of sand

Which held the sea from a harbor's mouth -

The loveliest in the land;

They kept their course across the bay,

And the shore before them fell away:

"O Pilot, see you not the strait that leads to the Eastern sea?"

"Hold the rudder true I Praise Christ Jesul the strait is here," said he.

Onward they glide with wind and tide,

Past marshes gray and crags sun-kist ;

They skirt the sills of green-clad hills,

And meadows white with mist -

But alas I the hope and the brave, brave dream I

For rock and shallow bar the stream:

"O Pilot, can this be the strait that leads to the Eastern sea?"

"Nay, Captain, nay; 't is not this way; turn back we must," said he.

Full sad was Hudson's heart as he turned

The Half Moon's prow to the South once more:

He saw no beauty in crag or hill,

No beauty in curving shore;

For they shut him away from that fabled main

He sought his whole life long, in vain:

"O Pilot, say, can there be a strait that leads to the Eastern sea?"

"God's crypt is sealed I 'Twill stand revealed in His own good time," quoth he.

Poems of American History, Burton Egbert Stevenson Houghton, Mifflin Co 


\title{
THE HUDSON-FULTON CELEBRATION COMMISSION
}

\author{
Organization and plans
}

HE Hudson-Fulton Celebration Commission was incorporated
by chapter 325 of the laws of 1906 of the State of New
York to arrange for "the public celebration or commemoration of the tercentenary of the discovery of the Hudson "river by Henry Hudson in the year 1609, and of the first use of steam in the navigation of said river by Robert Fulton in the year 1807, in such manner and form, either permanent or temporary, as may be found appropriate by said commission."

Under the provisions of the statute the officers of the commission are: president, Gen. Stewart L. Woodford; presiding vice president and acting president, $\mathrm{Mr}$ Herman Ridder; vice presidents, $\mathrm{Mr}$ Andrew Carnegie, Hon. Joseph H. Choate, Maj. Gen. F. D. Grant U. S. A., Hon. Seth Low, Mr J. Pierpont Morgan, Hon. Levi P. Morton, Hon. Alton B. Parker, Mr John E. Parsons, Gen. Horace Porter, Hon. Frederick W. Seward, Mr Francis Lynde Stetson, Hon. Oscar S. Straus, Mr W. B. Van Rensselaer, and Gen. James Grant Wilson; treasurer, $\mathrm{Mr}$ Isaac N. Seligman; secretary, $\mathrm{Mr}$ Henry W. Sackett. In accordance with the original statute and amendments and by appointment by the Governor of the State and Mayor of New York city the entire commission is constituted of more than 300 prominent citizens of the State including the presidents of 38 incorporated villages along the Hudson river.

The general program for the celebration as tentatively announced by the commission is briefly as follows:

Religious service days: Saturday and Sunday, September 25 and 26, 1909 Reception day: Monday, September 27 th

The people of Holland under royal auspices are building a reproduction of the Half Moon to be presented to the commission manned with a crew in the costumes of the period of Henry Hudson. The facsimile of the Half Moon will be formally received on Monday, September 27th and will take her place in line for the journey up the river. A facsimile of the Clermont, being built by the commission, will start from the original site with appropriate exercises and take her place in line. Public and private buildings will be decorated, visiting guests will be received, and exhibits of paintings, prints, books, models, relics etc. will be opened in libraries and museums in New York city and in similar institutions throughout the State.

Historical day: Tuesday, September 28th

On Tuesday, September 28th, there will be an historical parade in New York city, composed of floats and moving tableaux representing 
the principal events in the history of the city and State. The official literary exercises will be held in the evening at different places in New York city at which orations will be delivered by prominent men.

Generai commemoration day: Wednesday, September 2sth

Wednesday, September 29 th, will be devoted to the dedication of parks and memorials along the Hudson river and to general commemorative exercises in the schools, colleges, universities and other educational institutions and societies throughout the State. Other features of the day include a reception to visiting guests at West Point and an official banquet in honor of distinguished guests in New York city in the evening.

Military parade day: Thursday, September 3 oth

On Thursday, September 30th, will occur the military parade, participated in by the United States Army, the United States Navy and Marine Corps, the National Guard and the Naval Militia. It is expected that there will be 25,000 troops in line.

Hudson River day: Friday, October Ist

It is planned on Friday, October Ist, to have a parade of vessels of the navy, merchant marine, excursion boats and pleasure craft go from New York to Newburgh taking with them the facsimiles of the Half Moon and the Clermont. Simultaneously with the advance of the south Hudson division it is proposed to have a counterprocession from Albany to Newburgh, the two divisions meeting and holding appropriate ceremonies there.

Carnival day: Saturday, October $2 \mathrm{~d}$

Saturday, October $2 d$, will be the Children's day in all the cities, devoted to fetes in public and private parks and playgrounds. The celebration will culminate in New York city in the evening in a carnival parade, with moving allegorical tableaux, participated in by all nationalities represented in the city. It is also designed to have a chain of signal fires from mountain tops and other eligible sites along the whole river lighted simultaneously at 9 p. m.

Upper Hudson week: beginning Sunday, October $3 \mathrm{~d}$

It is planned to devote the week beginning Sunday, October 3d to celebrations in the communities along the upper Hudson. The naval parade with the Half Moon and the Clermont will proceed up the river and will participate in celebrations as follows:

Dutchess County day, Monday, October 4th, at Poughkeepsie; Ulster County day, Tuesday, October 5th, at Kingston; Greene County day, Wednesday, October 6th, at Catskill ; Columbia County day, Thursday, October 7th, at Hudson; Albany County day, Friday, October 8th, at Albany; and Rensselaer County day, Saturday, October 9th, at Troy. 


\section{OBSERVANCE IN THE SCHOOLS}

\section{$A^{\mathrm{s}}$}

noted in the plans of the Hudson-Fulton Celebration Commission, Wednesday, September 29th, has been set apart for the observance of the celebration in all the educational institutions of the State. A General Commemorative Exercises Committee, of which Pres. Jacob G. Schurman of Cornell University is chairman, has charge of this work for the Commission. At a meeting on March 3, 1909 of the executive committee of the General Commemorative Exercises Committee, of which the Commissioner of Education is a member, it was voted that the work of extending information to the schools of the State be devolved upon that officer. The Commissioner of Education therefore very earnestly urges all school authorities in the State to plan to hold commemorative exercises on Wednesday, September 29, 1909.

\section{Medals for essays}

In order to aid the Commissioner of Education in arousing interest in the schools in the real significance of the celebration, the HudsonFulton Celebration Commission, through its General Commemorative Exercises Committee, offers two medals to each high school and to each academy in the State for the best essays on the discovery of the Hudson river or of the application of steam to navigation thereon, one medal to be awarded to a boy and one to a girl in each school. Announcement has already been made in a circular issued to the schools on April 15. These essays are to be not more than 3000 words in length and are to be presented in the handwriting of the author to the principal of the school. The principal is to determine the award and certify the names of the winners to the Commissioner of Education not later than September 25,1909 . It is suggested that public announcement of the winners be made at the exercises on Wednesday, September 29th.

\section{Subjects for essays}

Pupils should be urged to select definite and specific topics for their essays, to study the subject thoroughly and then to write an original paper and not to make a mere compilation. The following topics touching upon the whole general question may be found helpful for essays in the prize contest and in the general composi- 
tion work in the schools: Henry Hudson and the Half Moon; Hudson's Journey up the River; An Imaginary Letter from Henry Hudson to a Friend in England Telling of his Reception by the Indians; Hudson's Last Voyage; Instruments Used in Navigation in Hudson's Time; The Relation of the Hudson River to the History of the State; The Scenery of the Hudson River; Legends of the Hudson River; The Industries on the Banks of the Hudson; Washington at Newburgh; History of Location of the Capital of the State; The Settlement of — [insert the name of town in which writer lives]; Robert Fulton's Career; Fulton's Disappointments; Fulton's Debt to Other Inventors; The Growth of Steam Navigation in 100 Years; A Description of the Clermont; Brief History of the Erie Canal; Description of an Ocean Voyage in 1609, 1809 and 1909 respectively.

\section{Subjects for debates}

1 That the Hudson river has been more important in the history of the United States than the Mississippi

2 That Europe is more indebted to Spain for its knowledge of the New World than to France, Holland or England

3 That the settlement of the New World by Europeans would have been impossible without the use of gunpowder and the invention of printing

4 That the Dutch took an unfair advantage of the Indians in purchasing Manhattan island for $\$ 24$ worth of trinkets

5 That the United States was better protected during the War of 1812 by the fame of Fulton than by the American navy

6 That the introduction of steam navigation was more influential in the growth of the State of New York than the Erie canal

7 That it would not be possible for the present city of Greater New York to exist without the steamboat and railroad

8 That the Five Nations were in some respects more civilized than the white people who came among them

9 That Hudson's last voyage was a foolish waste of human life

10 That the capture of New Amsterdam by the English in 1664 can not be justified

11 That the two greatest American inventions were brought into practical use by men who had been educated as artists

12 That Robert Livingston should share equally with Robert Fulton the credit for the introduction of the steamboat 
1 Map of New York showing locations with names of the principal Indian tribes in 1609

2 Map of New York in relief showing the old Indian trails and travel routes

3 Map of New York showing the principal cities and villages in 1810 with population of each, then and now

4 Chart showing titles and names of authors of 50 good books relating to the early history of the State of New York

5 Chart showing the titles and authors of 25 works of fiction touching on the early history of the State of New York

6 Graphic chart showing the growth of New York city, Albany and other Hudson river cities according to censuses from 1800 to 1900

7 Chart showing increase in Hudson river shipping from 1800 to 1900

8 Chart showing relative size and tonnage of the Clermont and the Lusitania

9 Chart showing relative horsepower of ordinary tugboat, the new Hudson river steamer Robert Fulton and the Mauretania

\section{Constructive work}

The sand tables in the lower grades and the hand work of the upper grades should serve to present very clearly to pupils the full meaning of the Hudson-Fulton celebration. The evolution of water transportation can be worked out. The smaller children can whittle out swimming logs, dugouts and rafts, and shape boats of bark, skin and reeds. The older children with the use of simple tools can make a model of the Clermont with its paddle wheels, stack and rudder, while ambitious boys in the manual training schools can make an almost exact model of the boat which can be used in all the grades to excite interest in the meaning of the celebration. Subjects for such constructive work are as follows: the Clermont, the Half Moon, a birch canoe, a canal boat, a canal lock, an Indian wigwam, a blockhouse, Dutch colonial house, colonial fireplace, a water wheel and mill. 
It is difficult to make suggestions for tableaux which will be applicable to all parts of the State, to the different conditions under which they are to be given and to the varying resources of the participants. Tableaux can be given out of doors with natural surroundings which can not be given indoors; and effects can be produced in a theater or a large auditorium which can not be had in a schoolroom. Each community must be guided largely by its own history, and each company by its own facilities.

While the primary object of the Hudson-Fulton celebration is to commemorate the achievements of Hudson and Fulton, it is designed also to stimulate the study of the local history of all the communities of the State. Therefore, any important or picturesque or interesting event in the annals of a town or city may appropriately be represented.

There are no more picturesque subjects than those relating to the Indians. If purely aboriginal life is to be represented, scenes may be given representing passages in the "Legend of Hiawatha," which is supposed to depict the origin of the Iroquois. If there is any local Indian legend, it may likewise afford material. Scenes in Indian domestic life; the making of pottery, wooden dishes, bows and arrows, etc.; the stringing of wampum; an Indian meal; the gathering of corn; the pounding of corn; Indian games, etc. are admirable subjects for purely Indian characters.

Then there is a range of subjects, as wide as the State, dealing with the contact between the Indians and the white men. The settlers of New York were usually very scrupulous to buy their land from the Indians, even if the price paid was small, so that from the purchase of Manhattan island by Peter Minuit in 1626 to the Big Tree Treaty on the Genesee by which the Senecas parted with most of their land, there were innumerable incidents of that sort. There were a great many councils with the Indians like that on Bowling Green, New York; that between Stuyvesant and the Indians at Albany (Fort Orange); those of Sir William Johnson at Johnstown; those under the Council tree at Geneva, etc. The dealings of the fur traders with the natives are susceptible of simple and effective representation. Cooper's "Learherstocking Tales" will suggest several picturesque scenes. Scenes of captivity may also be represented, and an incident like Mary Jemison's arrival in the

\footnotetext{
${ }^{1}$ Reprinted from a bulletin prepared by Edward Hagaman Hall L.H.M. L.H.D., and issued by the Hudson-Fulton Celebration Commission.
} 
Genesee country with her Indian babe on her back could be easily and strikingly portrayed.

Henry Hudson may be represented as signing his contract with the directors of the Dutch East India Company; or studying his globe and charts in the cabin of the Half Moon; or debating with his unruly crew near Nova Zembla whether he shall return to Holland or sail for America; or welcomed by the friendly Hudson river Indians. The famous feast, between Hudson city and Albany, when the Indians broke their bows and arrows to show their friendship, would make a striking scene. If facilities are available, a scene based on Collier's painting of "Hudson's Last Voyage," would be effective.

Any phase of Dutch colonial life would be good. A Dutch youth and maiden promenading together, or with the youth on his knees before his sweetheart, would represent a Dutch courtship. The rattle-watch - a darkened stage, with a watchman, going about with a lantern and whirling his wooden ratchet - could be easily produced. Men bowling at tenpins; or a Dutch school scene; or features of domestic life, such as spinning, weaving, threshing with a flail, churning by hand, polishing the pewter dishes, and cooking at the old fireplace, are good material to work upon.

What has just been said about the Dutch period is equally applicable to the English colonial period. A tea party of either colonial period could be made very pretty.

In preparing for the presentation of historical scenes, the first essential is to read the local history of the town and pick out its leading events. Some incident connected with the first permanent settlement of each town is particularly recommended. In New York city, the purchase of Manhattan island in 1626, as mentioned above, would represent the beginning of the Dutch period; the surrender of Fort Amsterdam by Peter Stuyvesant in 1664, the beginning of the English period; and the reading of the Declaration of Independence to the Continental Army, July 9, 1776, the beginning of the American period. The trial and acquittal of John Peter Zenger (1735) establishing the freedom of the press; citizens signing the nonimportation agreement (1765); citizens burning the British stamps (1765); Washington giving instructions to Nathan Hale (1776); Washington's farewell to his officers (1783) are suggestive of many others relating to colonial and revolutionary times. Where events are of national or state-wide importance there is no reason why one community. 
should not borrow subjects from another. Washington refusing the crown at Newburgh, the adoption of the Constitution at Kingston, the capitulation of Burgoyne at Saratoga, and the making of the first American flag flown in battle at Fort Stanwix (Rome) are events in the latter class.

Almost every community has had one preeminent historical character, like Peter Stuyvesant, George Clinton, Peter Schuyler, Kiliaen Van Rensselaer, Horatio Seymour, William H. Seward, or scores of others who could be named. Such a character, represented in his most famous attitude or act, would make a tableau by itself. Oftentimes a local statue will convey a helpful suggestion in this direction. "Living statuary" representing a soldier and sailor, would symbolize the Civil War. Robert Fulton's life suggests several subjects, such as taking painting lessons from Benjamin West; working on a steamboat model; making mechanical drawings; conferring with ex-President Jefferson, President Madison and others when he explained his torpedo plans, etc. Irving's "Sketch Book" can be drawn on for legends of the Hudson river, foremost among which is that of Rip Van Winkle and Henry Hudson's crew in the Catskills.

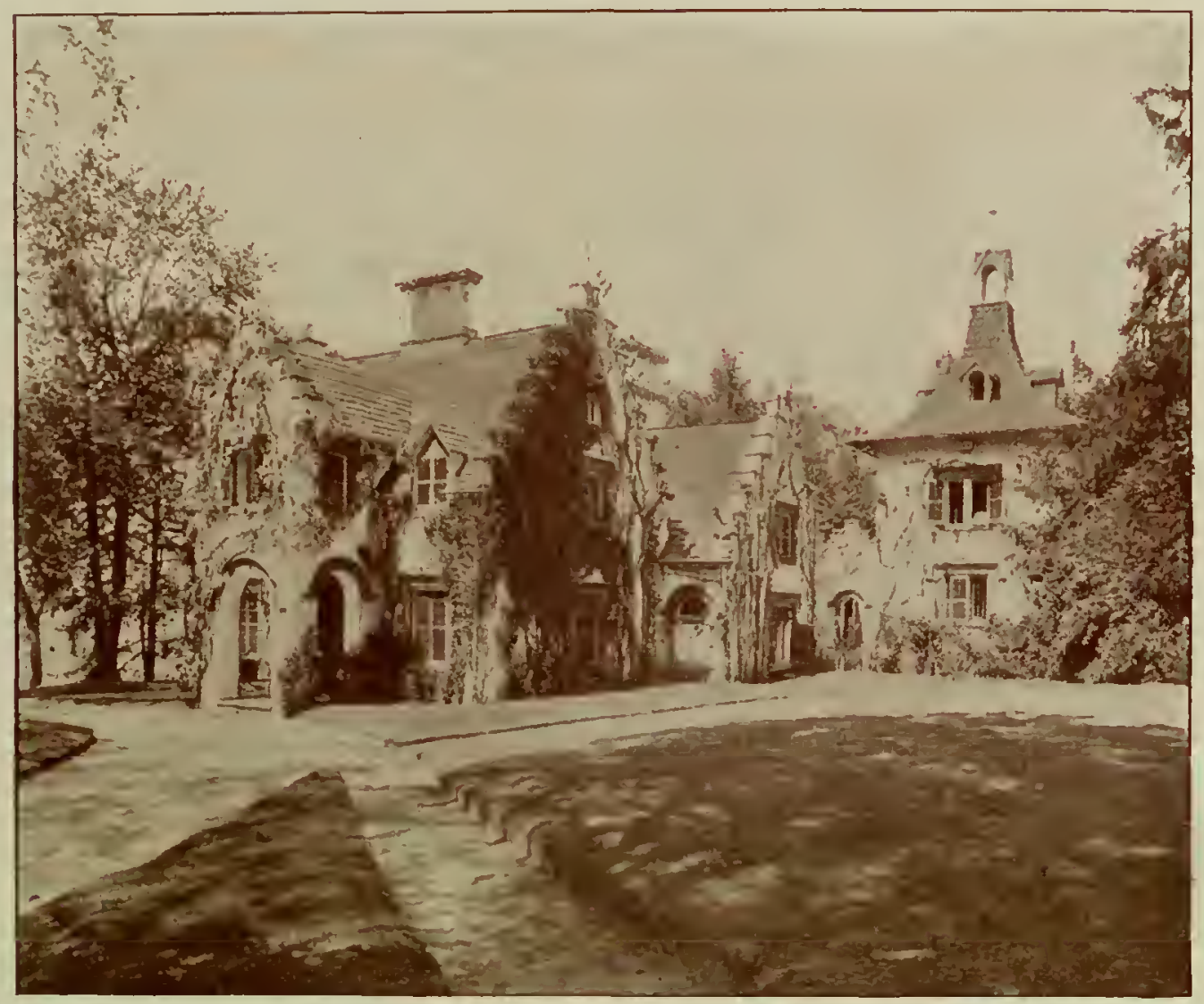

"Sunnyside," Irving's home on the Hudson 


\section{HUDSON AND THE RIVER}

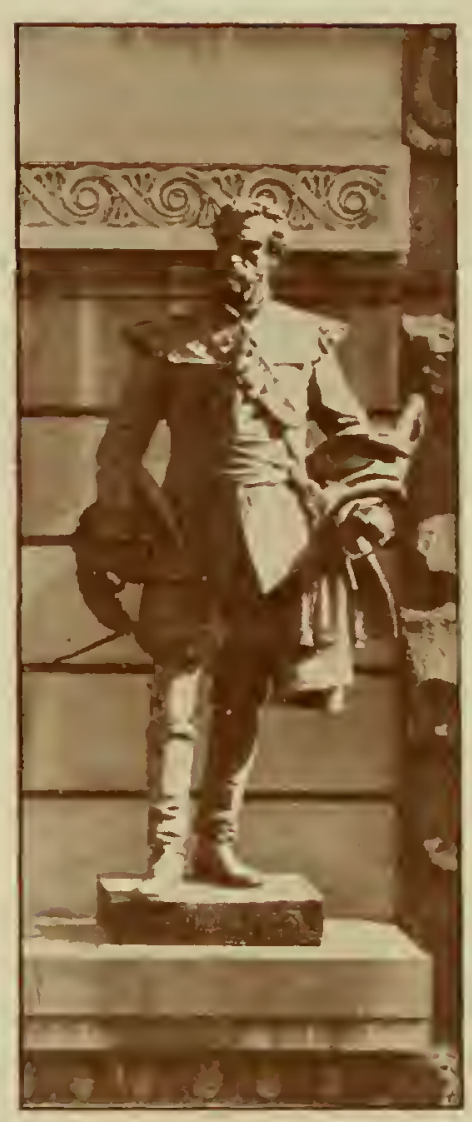

$\mathrm{Lss}^{\mathrm{Es}}$ is known of Henry Hudson than of other explorers of America in the 17th century; and all that is known of him is included within four years - from the May day in 1607 when he sailed from Gravesend for Greenland, until the fatal day of June in 1611, when he was cast adrift by his mutinous crew in the far northern James bay, and so passed forever into the unknown. We know nothing of his youth, his education, his associations, his personal appearance, his vocational training or experience, or anything about him, prior to his first recorded voyage, when he looms into view; but the years of which we do know are sufficient to reveal him as a man of large intelligence and enterprise, of abiding courage and indomitable will, which lift him into fame as conspicuous among those who opened the new world to the old, and especially as the pathfinder for the commerce and civilization of the Empire State. In the agreement with the Dutch merchants in 1609 he is described as "Henry Hudson, Englishman." This doubtless settles the country of his birth. It is suggested that he was a grandson of another Henry Hudson, who was an incorporator of the Muscovy Company, but this is a mere conjecture based upon the identity of the Christian name of each and the interest of other Hudsons in the company. It is said by some that he had been a master of Dutch vessels, and by others that he was with the Muscovy Company before he was sent by the latter on his arctic voyage, but it may fairly be stated that he was then a skilled seaman. He was about 40 years old and was married, for he had a son who accompanied him in his expeditions and perished with him, and there is reference to other children in the subsequent contract with the Dutch East India Company.

The Muscovy Company, trading in Russia, was anxious to find a northwest passage to China. This was the dream that entranced many hardy mariners of the day. It was the dream of Hudson, 
who was willing to brave dangers and mischances that he might realize it. So the company hired him, and on May 1, I607 he set out from Gravesend in a craft of 80 tons, the Hopevvell, with a crew of 11 men, some of whom were turbulent and worthless fellows, as was the case also with his succeeding crews. In six weeks he reached Greenland and named the first land seen Young's cape after one of his men, a name it still retains. Thence he headed north to $72^{\circ}$ on the coast and steered for Spitzbergen, touching $80^{\circ} 23^{\prime}$ and holding the record for ' f farthest north" until Captain Phipps in 1773 went $25^{\prime}$ further north. He perplexed himself in vain about a northwest passage, and by this time his men had become restive and even rebellious and clamored for home. He was obliged to yield to them, and turning his prow eastward put into Tilbury docks on the I5th of September, having been plagued throughout a large part of his course by thick fogs and tempests and pounding ice floes. The voyage was a disappointment. Nothing had been accomplished except the high northern mark. Other adventurers had preceded him in their visits to the arctic region. But he still had his stout heart.

Hudson's second voyage was under the same support and probably in the same small but stanch vessel as the first: It was an effort to find at the northeast that which had baffled him at the northwest communication with China and the Indian ocean. He left St Katherine's docks on the 22d of April 1608, coasted western Norway, rounded Cape North on the $3 \mathrm{~d}$ of June, and after much buffeting by the ice rested in a quiet cove of Nova Zembla on the 1st of July. He was soon satisfied that further search at that time would be useless, and "being void of hope," as he says, "the wind stormy and against us and with much ice driving, we weighed anchor and set sail west." He was back on the Thames on the 26th of August, to be coolly received and even scolded by the company for his failure, and his relations with it ended. His own ardor, however, was not eclipsed by his rebuff. The dream still possessed him. There were other ways to try and other patrons to ask.

Like "soldiers of fortune" with their swords drawn at any bidding, a number, if not a majority, of the discoverers and explorers of America were aided by governments and associations other than those of their own nationality. Some tramped from court to court, cap in hand. Columbus, a Genoese, was commissioned by Isabella of Spain; Cabot, an Italian, by Henry VIl of England; Verrazano, a Florentine, by 
Francis I of France; Gomez, a Portuguese, by Charles V, the German Emperor; and Americus Vespucius was in the employ of both Spain and Portugal. It is not singular that the English Hudson, doubtless angry with the Muscovy Company, should make terms for his third and most memorable voyage with the Amsterdam Chamber of the great Dutch East India Company at a time when the Netherlands, despite the exhausting war for her liberties in which she had been engaged with Spain, was pushing to the front as a world trader, when the scepter of commerce was passing from the Rialto to the Zuyder Zee. After considerable delay an agreement was concluded by which the company was to furnish a vessel of about 60 tons burden (the

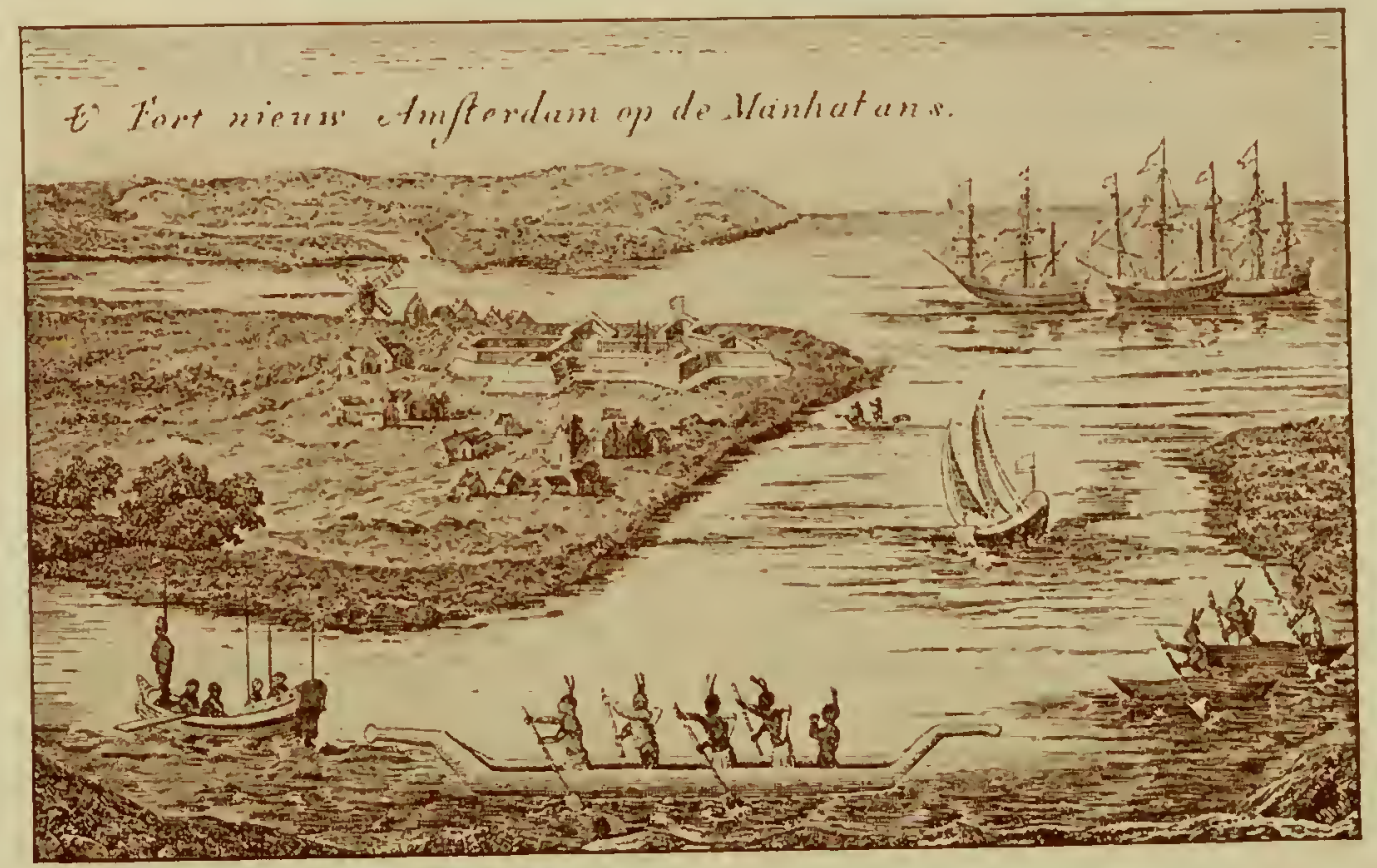

First view of New Amsterdam

Half Moon) in which Hudson was to sail "by the north around the north side of Nova Zembla, thence by a southerly course to the latitude of $60^{\circ}$," still to seek the fabled passage to the East, and the injunction was strict that no other route should be attempted. For his personal outfit and the support of his family he was to receive $\$ 320$ and $\$ 80$ additional was to be paid to his wife in case of his death, with a provision for further compensation at the discretion of the directors - a paltry sum and an indefinite promise suggesting a secret understanding and an option as to the course he should pursue. His crew was again a motley one-Dutch, English and Asiatics - less than 20 in all, unruly and unmanageable, men meaning to be masters. As has been seen it was always his fate to have such a crew. 
He left Amsterdam April 4, 1609; in about a month he was off the North cape again, but Nova Zembla was not reached; the ice was obstinate, some of the crew were sick, others were doing double duty, and all were dissatisfied. So the choice was given them to point for America at about $40^{\circ}$, or to try to reach India by way of Davis strait at the north. The latter was selected, and Hudson, disregarding the company's instructions, made the Newfoundland banks, July 2; thence he coasted southward to Penobscot bay, to Cape Cod, by New York harbor, to James river, to South Carolina, and then back to the Chesapeake, with a run up the Delaware; and on the $2 \mathrm{~d}$ of September the Half Moon cast anchor in "a great lake of water, as we could judge it to be," with high hills to the northward"a very good land to fall in with and a pleasant land to see," as runs the quaint chronicle. For about 10 days Hudson remained in the lower bay of New York, taking soundings and having intercourse, both friendly and otherwise, with the Indians who crowded about the ship. On the 12th of September he went up the bay to the Battery and entered the river, yet with the thought that it might be a channel that led the way to the coveted spices and precious stones of the East. The story of the ascent and descent of the river is a familiar one and needs here to be but briefly told. On the 13th he was at Spuyten Duyvil; the 14th at the Highlands; the 15th within view of the Catskills; the 18th opposite the site of Hudson city; on the 19th he was trading with the natives, a few miles below Albany; on the 20th a small boat was sent north to prospect, the Half Moon riding at anchor; on the $22 \mathrm{~d}$ the boat returned to report that it had gone about 27 miles, probably to $W$ aterford, that the river narrowed and shallowed all the way, and that the dream of the northwest passage, by this stream, must be abandoned. On the $23 \mathrm{~d}$ the descent began, and after various adventures and some serious encounters with the Indians the bay was again seen on the $3 \mathrm{~d}$ of October. The next day with fair weather and a favoring breeze the Half Moon trimmed her sails for the East, and was the first ship which left the port of New York direct for Europe. How many thousands have followed in her wake! The original destination was Ireland, whence further American explo. ration was to be made, so determined by a compromise with the crew, which was as usual of a mutinous spirit, sullenly refusing to return to Holland. But, either accidentally or by design of the master, Dartmouth in Devori was the port arrived at on the 7th of November. There both vessel and captain were detained by the English authorities; 
the former, however, was subsequently released, and returning to Holland was wrecked in East Indian waters a few years later, while the latter, as an English subject, was forbidden to leave the country.

Hudson's career may now be speedily followed to its close. In 1610 certain members of the Muscovy Company. Sir Thomas Smith and Sir Dudley Digges being among them, fitted out for him the ship Discoverer, with which according to the Rev. Samuel Purchas, who wrote much concerning Hudson, he was "to try if, through any of the passages which Davis saw, any passage might be found to the other ocean called the South sea." The dream persists. On the 17th of April he sailed from London with an especially ugly crew of 20 men, touched the southern end of Greenland, and on the 1 lth of July anchored at Baffin land on Hudson strait; thence entering Hudson bay

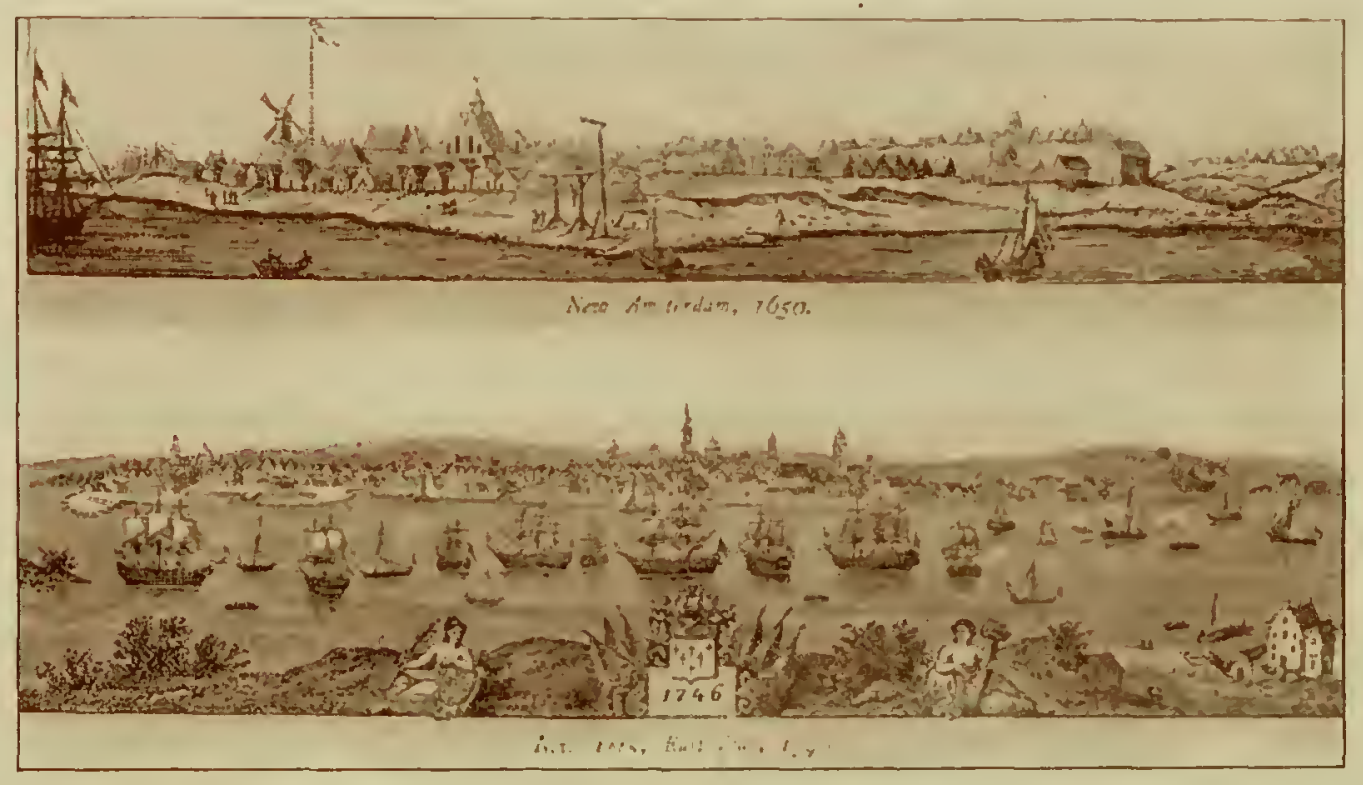

he rested in James bay at its southern extremity some time in September. Therein he was icebound and the winter was spent with much of idleness, bickering and complaint by the crew, and the final shattering of his hope of penetrating to China. He had met with his fourth failure in his zealous pursuit. On the 18th of June 1611 he began his homeward trip, but now mutiny was openly declared against him, and measures for his "taking off" were planned. The severity of his discipline was alleged as his chief offense, in part accounting for but not excusing the tragedy that ensued. Four days later with the sick and lame, his son John and the ship's carpenter, faithful to the last - eight in all--he was thrown into a shallop and the ship bore away. The crime was one of peculiar atrocity. The curtain falls upon the mystery of his fate, but rises upon his imperishable renown. 
What did Henry Hudson accomplish? Broadly it may be stated that he discovered the bay and explored the river to each of which his name is attached. Not many years passed before he was followed to the bay by Button and Fay and Cox, and half a century after his death the Yankee captain, Zachariah Gillam, led an expedition thither which resulted in the building of the first fort on its shore and in the organization of the famous Hudson's Bay Company, whose colossal operations have lasted more than two centuries. When the controversy between England and France for the possession of the immense territory that surrounds it became acute, it was upon the exploit of Hudson that England based her claim to priority of title. But it is in his relation to the river and its features, associations and history that we are chiefly interested. Of it in the strictest sense he can not be said to be the discoverer. Others had previously seen it. Verrazano in 1524 beheld the "Grandissima riviera" at its mouth, as probably did Gomez in 1525, who named it "Rio de Sanet Antonio," and it is thus indicated on a map drawn by Alonzo Chaves, a Spanish cartographer, in 1537. Stephen Bellinger, a Frenchman, in 1583 coasted southwesterly from Cape Breton, 600 miles, "and had trafique with the people in tenne or twelve places." The shore of the river may have been one of these. And there are vague accounts of both French and Dutch visitations prior to 1609 , but Hudson saw, observed and investigated from tide water to the head of navigation.

The Dutch immediately assumed title to the river and to lands westward of it by right of Hudson's exploration - not an uncontested and at the last a voided title - for the English claimed by virtue of Cabot's discoveries all lands on the North American coast north of Florida, and the English crown made grants accordingly. They also claimed, because of Hudson's nationality as superior to his Dutch engagement. The Indian name of the river was Shatemuc; Hudson called it the Mauritius, after Prince Maurice; the early colonists, the North, by which it is still sometimes known; but eventually it was properly named the Hudson. In their first operations the Dutch were not materially molested by any other power. Trade with the Indians for furs began at once. In 1610 the fur merchants of Amsterdam dispatched for that purpose a vessel with Hudson's former mate, Van Kampen, as master, the venture being a profitable one. In $1611 \mathrm{Hen}^{-}$ drick Christiaensen took to Holland two Indian boys, the sons of a Manhattan chief. In 1611 five ships were sent out from Holland, and certain famous sailors, Christiaensen, Block and May, appeared 
upon the scene, driving lucrative bargains and making some notable discoveries in adjacent waters as well. Within a few years several forts or bastions were erected, Nassau, a mile or two south of Albany, and one, perhaps two, on Manhattan being among them; and settlement, as yet wholly for traffic with the Indians, may be said to have begun. In 1614 that eminent buccaneer, Samuel Argall, compelled the Dutch at all their forts to lower their own and raise the English flag, and then sailed away, the English flag being promptly pulled down after he left. In the same year the States General of the United Netherlands gave a charter for a limited number of voyages to the New Netherland Company to trade exclusively in the newly

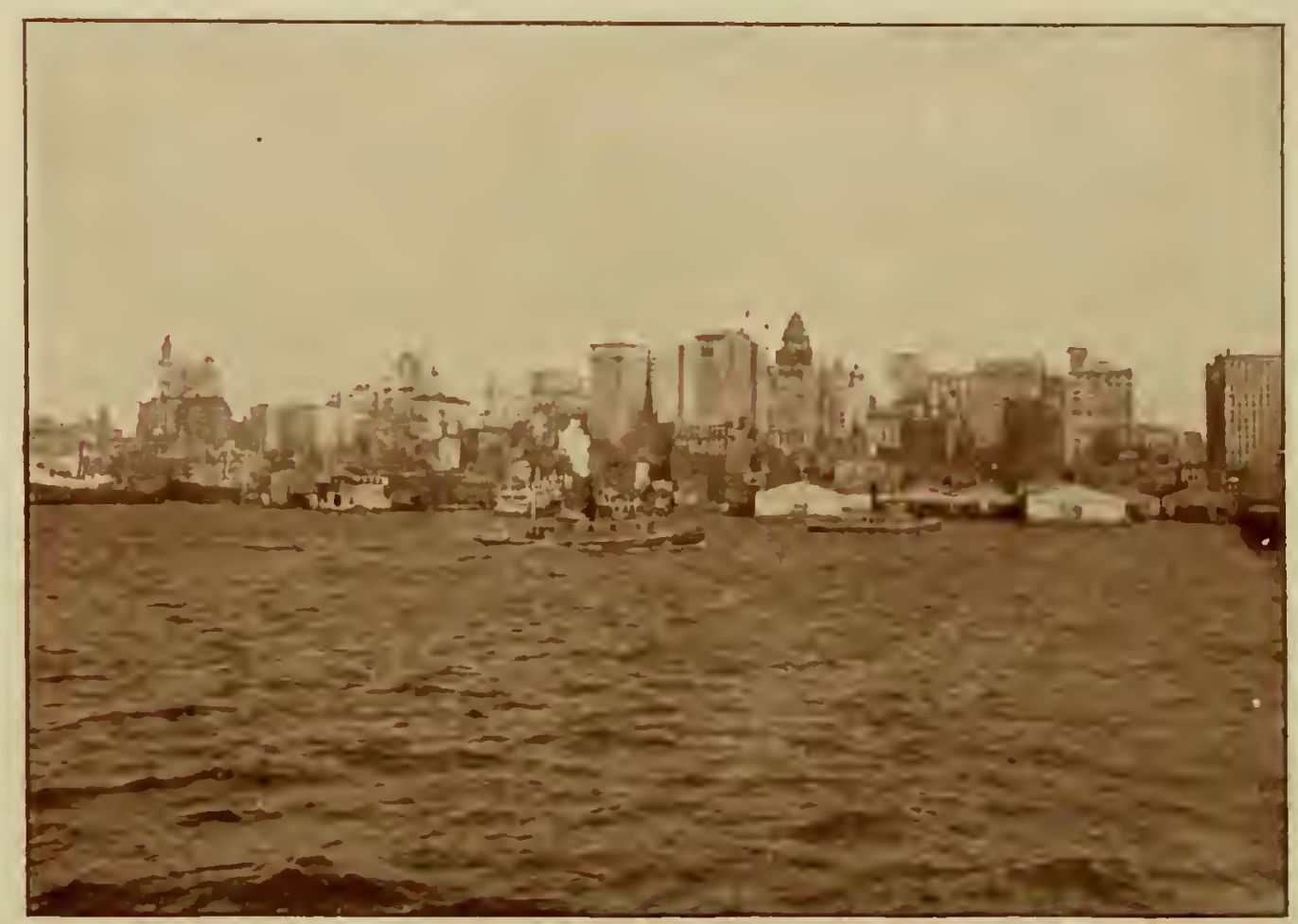

New York harbor

discovered lands between the 40th and 45th degrees of north latitude - that is, between New France and Virginia, so expressed-and specifically describing the region as New Netherland. In 1618 a notable compact was made by the command at Fort Nassau with the Iroquois on a hill at the mouth of the Tawasentha - Norman's killa few miles below Albany for the exchange of peltries and weapons of war. It was the basis of a warm and enduring friendship of the Iroquois and Dutch, to which the English succeeded, that was of immense benefit to the latter and of serious harm to the French and Algonquins. In 1621 the States General issued the celebrated charter to the Dutch West India Company, with its enormous jurisdiction and 
extraordinary franchises; and two years thereafier the company sent out the ship New Netherland with thirty Walloon families; a part of them settled in what is now the borough of Brooklyn, and a part at Fort Orange on the site of Albany. Colonization was a fact. In 1626 Peter Minuit was made Director General with residence in New York, and purchased Manhattan island from the Indians for 60 guilders $-\$ 24$. Thus Dutch estates, usages and institutions were introduced into New Netherland, and these remained even after the English conquest in 1664. Their influence is still felt in New York.

It would be beyond the limits of this article to enlarge upon the influence of the Dutch in molding our State. A few words must suffice. First of all it is to be noted that New Netherland was the child of the Dutch Republic, then the most intelligent, the freest and the most enterprising nation of Europe. The founders of the new state brought with them the principles of the old; and they also opened wide the door to the refugees of all nations from either political or religious persecution. New Amsterdam was cosmopolitan from the beginning. It is said that 18 languages were spoken there before 1650. The Swedes came to Manhattan, the Waldenses to Staten island, the Walloons and English to Long island and the Huguenots to Ulster county. The Dutch originated the vital principles of our institutions, municipal and township organizations, and the idea of local self-government. To these they held firmly in their representative bodies - the "twelve men" and the "eight men." They uniformly opposed arbitrary taxation. Above all else, it is to be remembered that on the Hudson in 1633 the first public school in the land was established. If it be said that the feudal powers granted to the patroons on their manorial estates did not correspond with the general prevalence of popular government, it may be replied that for these the West India Company, and not the States General, was responsible; that in 1638 and 1640 the prerogatives of the patroons were materially restricted and the rights of free settlers materially enlarged, and that wherever the numbers in the settlements were sufficient the company was bound to guarantee them local self. government.

The Hudson, the second of any river of considerable size on the continent to be explored, the St Lawrence being the first, is 300 miles in length, and is navigable by vessels of the first class for about 150 miles. Its general direction is southerly - due south in its navigable portion. It drains an area of about 30,000 square miles above the entrance of the Mohawk. Among its tributaries are the Schroon, 
Batten kill, Hoosic, Wappingers and Croton on the east, and the Sacandaga, Mohawk, Wallkill and Esopus creek from the west. There are longer rivers in the land, but few with fuller flow. There are those along which nature is tossed into more weird and awful shapes, with deeper chasms and loftier cataracts, but there is none upon which there is a greater variety of scenery, from the beautiful to the sublime, as there is none more serviceable. During its entire course there is no spot which is not invested with interest, either natural, legendary or historical, from the silken skeins of mist and the bubbling springs at its sources in the Adirondacks, to the magnificent bay upon which the navies of the world may ride, where the queenliest of cities

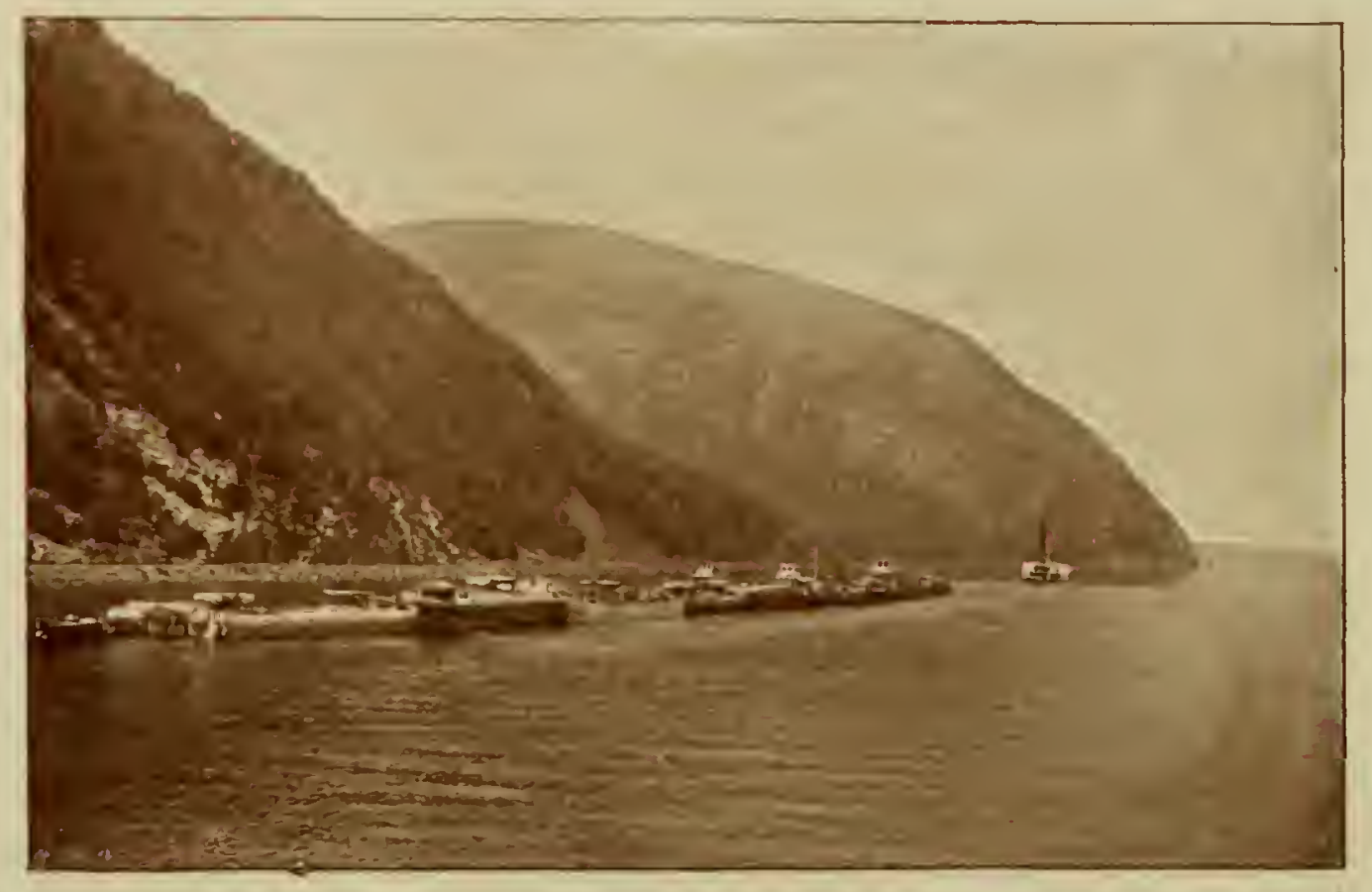

Storm King

receives tribute from the commerce of all the zones. Especially notable are the series of rapids and cascades at Glens Falls, the water rushing over ragged masses of black marble through a descent of $80 \mathrm{feet}$; the Catskills, a wonderful procession of peaks and slopes, and recesses; the picturesque Highlands; the solitary grandeur of Storm King and Cro' Nest; the majesty of the Palisades, battlements rock-ribbed and perpendicular, sheer from the water's edge to hights of 250 to 500 feet; the broad expanse of the Tappan Zee, and the noble sweep into the Atlantic. The Hudson is a peerless stream. It is often compared with the Rhine, but the Rhine is not so uniformly fascinating in its natural features as the Hudson, and is admired less for these than for the castles and ruins on its banks. The Hudson is lined by princely 
estates, thriving villages and prosperous cities. Of the latter there are in New York State eight - Cohoes, Albany, Hudson, Kingston, Newburgh, Poughkeepsie, Yonkers and New York, already the second and soon to be the first market place in the world; and in New Jersey are Hoboken, Jersey City and other populous communities. Over $5,000,000$ people reside on, or contiguous to, the banks of the Hudson - a multitudinous host, an imperial domain.

There is no section of the country that is of larger historical signifcance than that of the Hudson. It has witnessed its own exploration and colonization by one people and its surrender to another; a portion of the conflict between two great European nations for the possession of the continent; the first congress of the colonies for mutual protection; the provincial struggies for popular rights; the battles of the Revolution most intimately related to its successful issue; the organization of the federal government; and the evolution politically and economically of the foremost commonwealth of the United States. Some of these events have already been referred to and but a glance at others may be indulged in.

The Dutch held sway in New York for about 50 years, the last Dutch governor being Peter Stuyvesant, a very hard-headed and hotheaded, one-legged man, who stumped New Amsterdam in unavailing rage when on August 29, 1664 Richard Nicolls sailed up the bay and demanded in the name of his sovereign, Charles II of England, then at war with Holland, the surrender of the "towns situated on the island commonly known by the name of Manhattoes, with all the parts thereunto belonging." English rule began September 8th, the transferred province being renamed New York after the Duke of York, subsequently James 11, and continued with an interval from August 1673, when the Dutch under Captain Colve seized it and administered its affairs, until November 1674, when it reverted to England under the treaty of Westphalia. From 1674 until 1683 Sir Edmund Andros, the ablest and most energetic of the crown governors, was at the helm, returning in 1688 as governor in chief and captain general of all the northern colonies. He strengthened defenses, increased trade, augmented the revenues and beautified the city. In 1683. Thomas Dongan being governor, the "Charter of Liberties" was declared, by which the supreme legislative power was vested in a governor, council and the people met in a general assembly - the first recognition of the people in any American constitution. In the same year the first 10 counties, six of which - Albany, Dutchess, New York, Orange, Ulster 


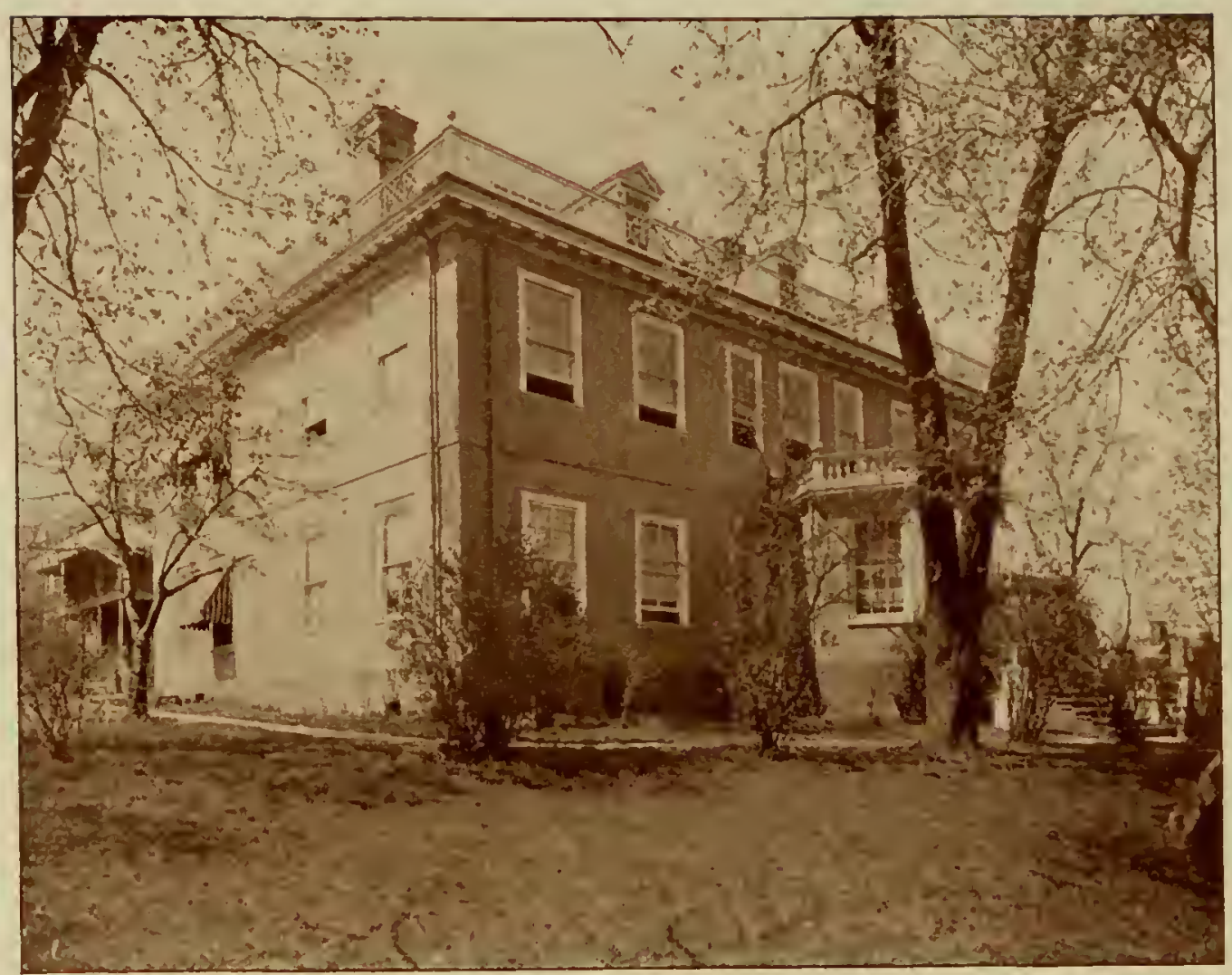

FROM A RECENT PHOTOGRAPH

Schuyler Mansion

Erected at Albany by Gen. Philip Schuyler in 1761. Here, on Dec. 14, 1780, Alexander Hamilton and Elizabeth Schuyler were married.

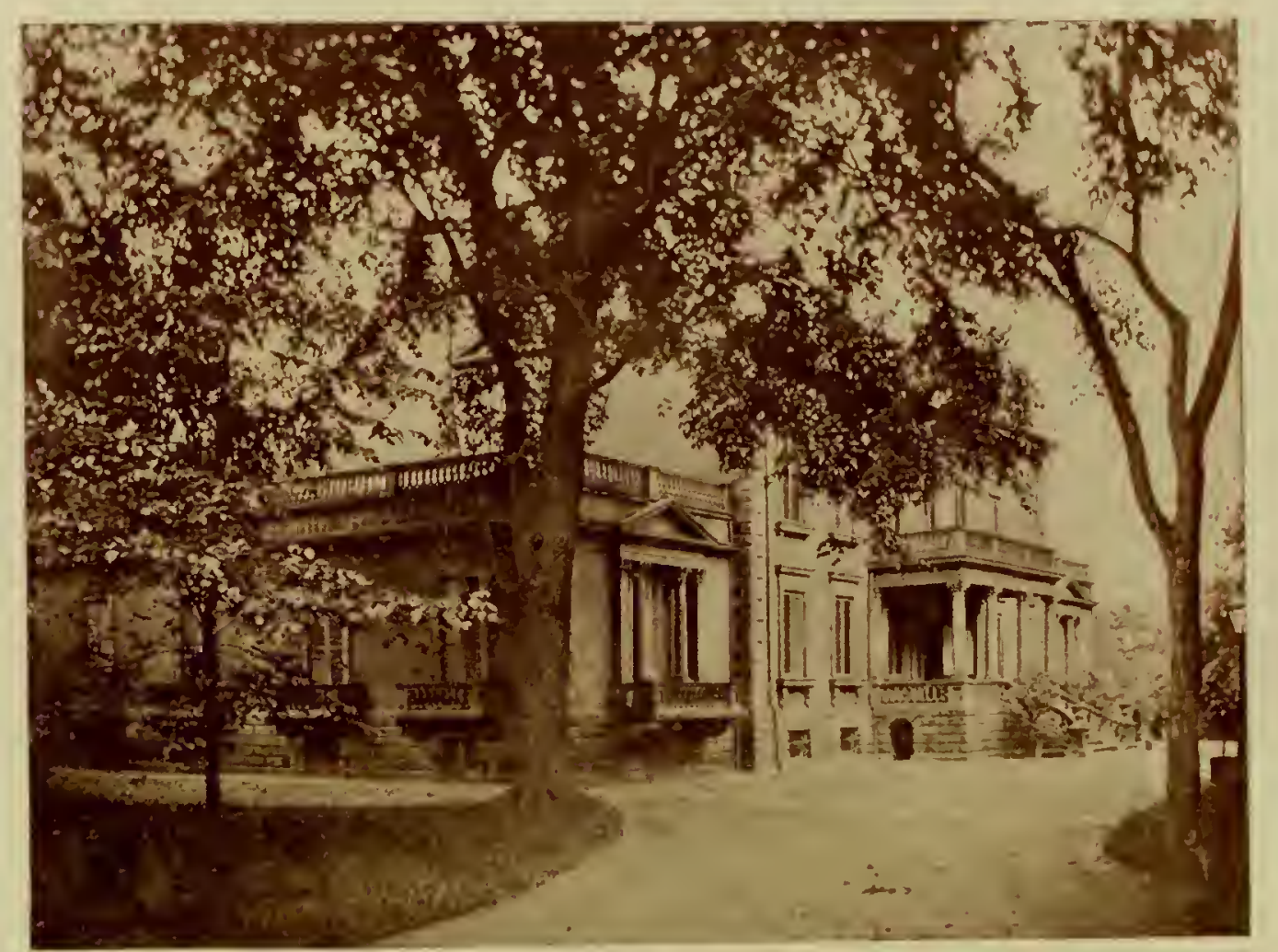

FROM PHOTOGRAPH IN POSSESSION OF MRS LAUHA VAN RENSSELAER, ALBANY

Van Rensselaer Mansion

Erected at Albany by Stephen Van Rensselaer in 1765; remodeled in 1843 and removed to Sigma Phi place at Williams College in 1893. 
and Westchester - are on the Hudson, were erected. Kings on the East river may also be classed as within the territory of the Hudson, while the remaining counties - Queens, Richmond and Suffolk - it may not be proper to claim. In 1735 the liberty of the press was vindicated in New York in the celebrated case of John Peter Zenger, acquitted on a charge of libel by the eloquent plea of Andrew Hamilton. In 1754 a congress of the northern colonies was held in Aibany, at which a plan of union drafted by Benjamin Franklin was adopted. It was not carried, but it was the herald of their future cooperation. On the 18th of October 1764 the New York Assembly authorized a correspondence with other colonies concerning the acts of Parliament relative to trade and upon the danger of being taxed unreasonably by the mother country - the first official proposition in behalf of American union for American interests, anticipating by two years the action of Massachusetts at the instance of Samuel Adams, to the same purpose.

The Hudson bore the brunt of the Revolution. It was the scene of its most stirring incidents, of its crucial conflict, and of the evacuation of the country by British troops, November 25, 1783. There Washington revealed his consummate military genius by withdrawing his shattered troops in the face of overwhelming numbers to win the victories of Trenton and Princeton. On its lower shores was the debatable ground where patriot and tory were in constant feud. On the 17th of October 1777 at Schuylerville Burgoyne surrendered, as the outcome of the batties of Bemis Heights, generally known as the field of Saratoga. The story is a familiar one - the scheme to separate New England from the other colonies by uniting the troops of Burgoyne and Howe on the upper Hudson; the failure of Howe to ascend; the advance of Burgoyne by way of Lake Champlain; the well devised plans of Schuyler to meet the invasion; his cruel retirement from command and the succession of Gates; the fall of Ticonderoga; the retreat from Fort Edward to an advantageous position; the breaking of British communication with the Canadian base; the cordon drawn about Burgoyne; the sharp engagements and the laying down of arms. Nowhere on American soil is there a spot more sacred than that of Saratoga. There was the signal American triumph, and there the signal British discomfiture, presaging ultimate British defeat. "The Revolution," says Senator Lodge, "was saved at Trenton: it was established at Saratoga." On the 15th of July 1779 "Mad Anthony" Wayne captured Stony Point, the "Gibraltar of the Highlands," as Irving calls it - one of the most brilliant exploits of the war, distinguished alike for 
its difficulty and daring. It is in sharp contrast with the infamy of West Point, a year later, when Benedict Arnold, the dashing fighter of Quebec, Valcour and Saratoga, the beloved and trusted lieutenant of Washington, harassed with debt and smarting at the neglect of Congress, tried to betray the fortress into British hands for British gold; and, thwarted in this, sneaked down the Hudson leaving the British emissary, the gifted and noble André, to be executed as a spy, for his (Arnold's) treason.

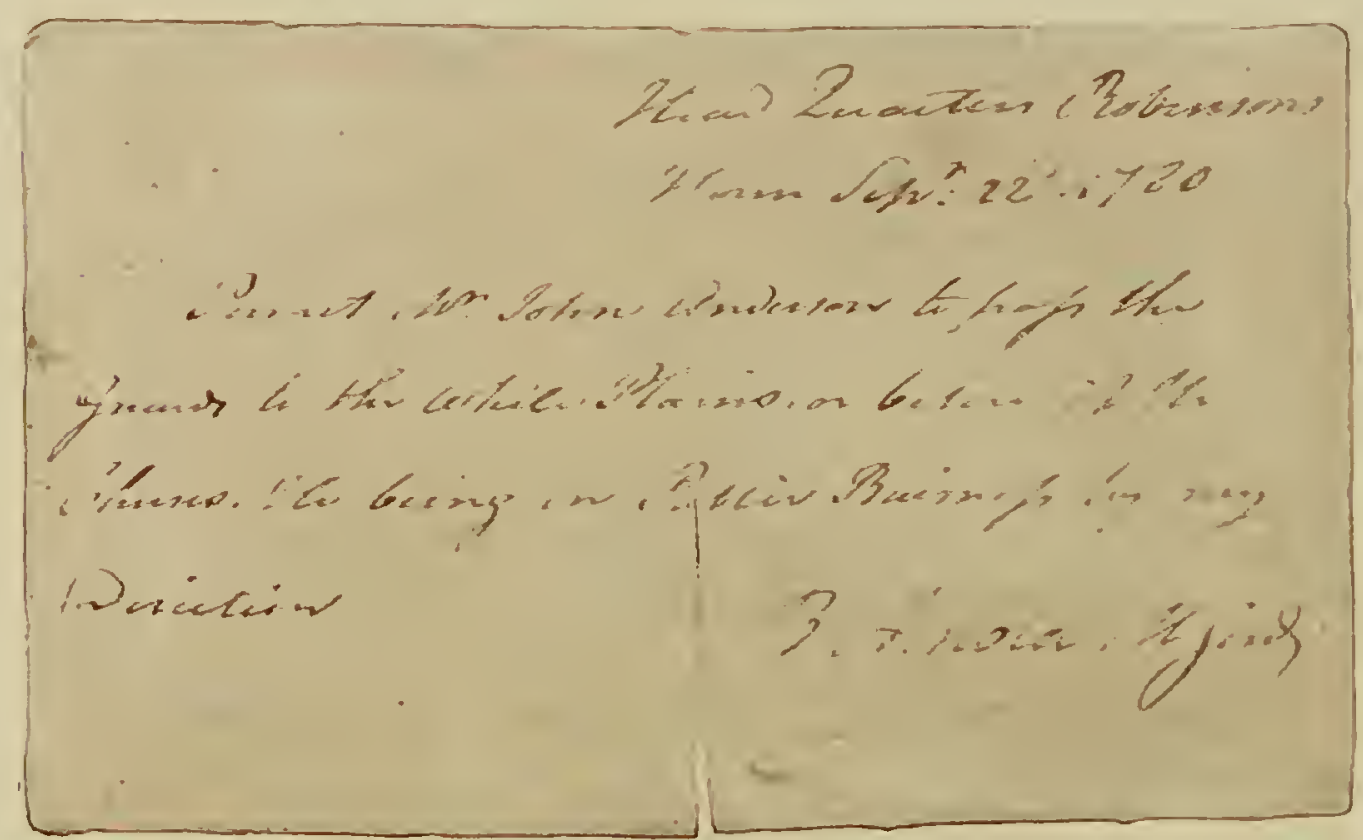

Reproduction of pass in Arnold's handwriting found with other papers in Major Andre's boots when he was captured. The André papers were acquired by the State of New York with the George Clinton papers in 1853 and are now in the State Library.

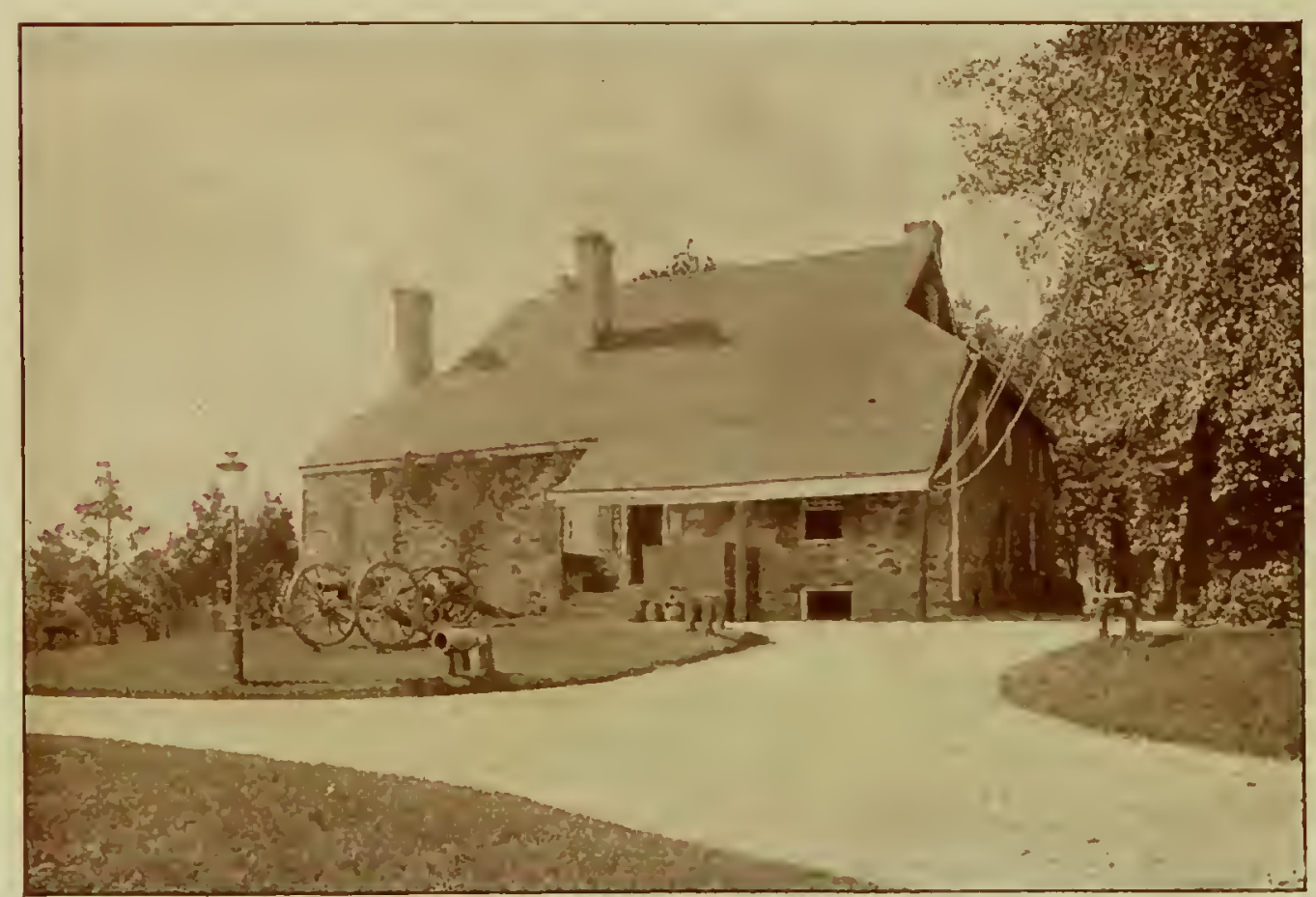

Washington's headquarters at Newburgh 
On April 20, 1777, at Kingston, New York declared itself an independent state and adopted a constitution; and on the 9th of July George Clinton, soldier and statesman, became the first governor, serving as such continuously until 1804, save for the intervening term of John Jay - 1795 to 1801 . Driven from Kingston by the incursion of the enemy and the burning of the place, the Legislature held its second session in 1788 at Poughkeepsie, and for the next six years wandered from Poughkeepsie to Kingston and Albany, as the fortunes of war determined its safety. In 1784 it met in New York and there remained until 1786 with the exception of holding sessions at Poughkeepsie in 1788 and 1795 and at Albany in 1789 and 1794. In 1797 the capital was located permanently at Albany. At his headquarters in Newburgh in 1782 Washington could have founded a kingdom and become its king. Royal state was pressed upon him, but he indignantly refused its proffer and sternly rebuked the devoted officers who made it; and at Newburgh in 1783 he disbanded the continental army. In 1788 at Poughkeepsie, New York ratified the federal Constitution, mainly by the persuasion of Alexander Hamilton, her great constructive statesman; and on the 30th of April 1789, George Washington on the balcony of Federal Hall in Wall street, took the oath of office as President of the Republic he had created, New York remaining the seat of the general government until December 1790 . Thus, on the Hudson, statehood was ordained, the monarchy rejected, the national Constitution confirmed, and the nation itself established. Of the 36 governors the State has had, 20 have hailed from the Hudson; and it has given to the Union four presidents - Van Buren, Arthur, Roosevelt, and Cleveland as he entered upon his second term.

It will be impossible to detail the history that has been made upon the Hudson since New York became a state, or even to mention the names of many of her citizens who within the period indicated have guided her progress or contributed to her prestige and power: but a few may be alluded to. The 11 th of July 1804 was perhaps the saddest day in the annals of the State, when at Weehawken on the Hudson, Aaron Burr fatally wounded Alexander Hamilton in a duel, leaving Hamilton's memory sacred as a martyr, as he was already exalted as a statesman. On the 7th of August 1807 Robert Fulton steered the Clermont from New York to Albany - the first successful attempt at steam navigation, the second illustrious ascent of the Hudson, fitly commemorated in connection with the first. At the mouth of the Hudson on the 26th of October 1825 DeWitt Clinton, 

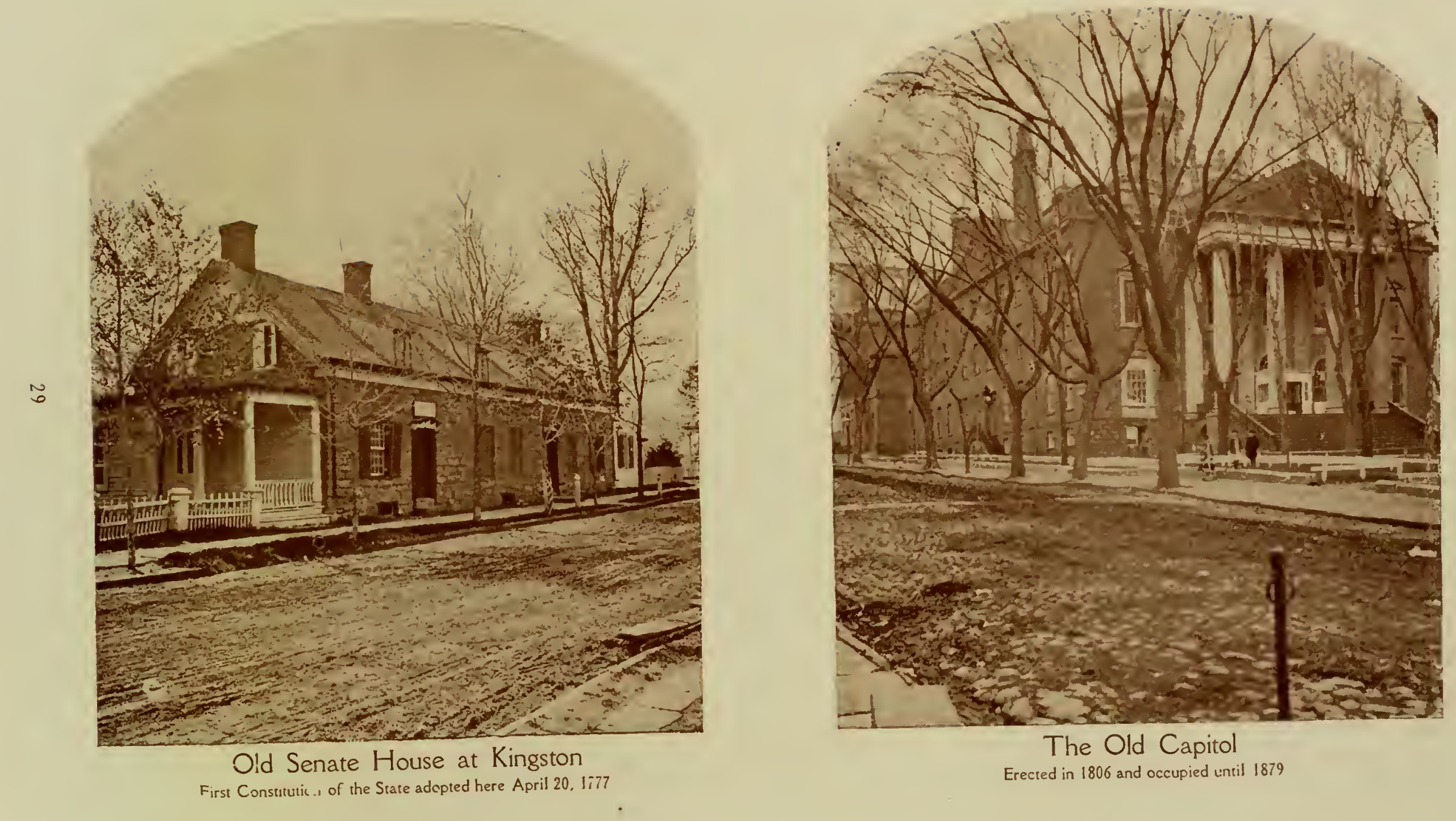
as the happy phrase says, "married Lake Erie to the Atlantic," and the great artificial channel which crosses the State from west to east and empties into the Hudson at Cohoes was opened to the commerce of the continent. In 1784 the Regents of the University met in New York and granted a charter to Columbia College; in his message of 1795 Governor George Clinton recommended the establishment of common schools and annual appropriations for their maintenance ensued, and in 1812 the Legislature at Albany organized the State common school system which, in its principal features, has been adopted by nearly every American state. And throughout, while credit is to be given to the representatives from all sections for the 130 years of legislation promotive of the common weal, it is not to be forgotten that all legislation has been enacted on the Hud'son. The business energies of the State have there.also had their utmost conspicuous expression. It has both the capital and the metropolis.

In the harbor of New York stands the typical figure of "Liberty enlightening the world." It symbolizes also the intellectual supremacy of New York where Bryant sang and Irving wrote and Morse invented. The empire of mind there declares itself in letters and science and the arts, in the multitudinous sheets of the daily press, in museums and galleries and observatories and universities, in professional standards and rewards, in the acquisition and diffusion of knowledge. The story of the Hudson is here told as fully, if not as adequately, as space permits. In the charm of its scenery, in its legends as told by Irving and other writers, in its history, in its political rank and martial glory, in its growth and commerce and wealth, in all the appointments of civilization, where is its superior? Henry Hudson explored better than he knew when he sought the gems of the east and held the promise of the west.

\section{Charles Ellott Fitch}

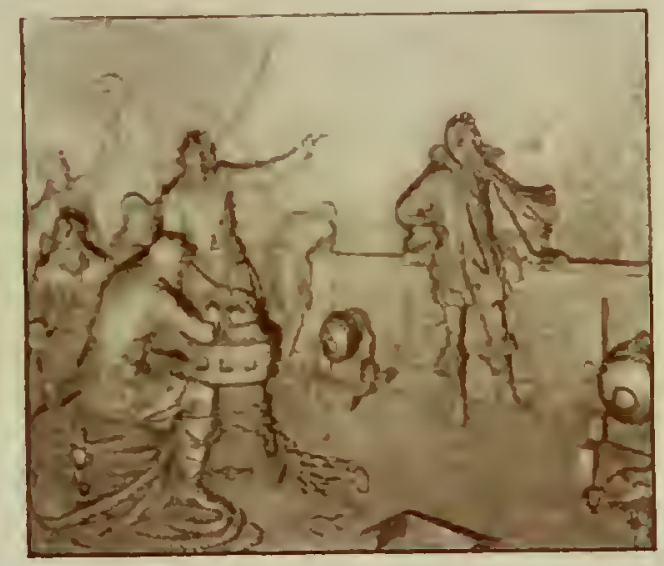




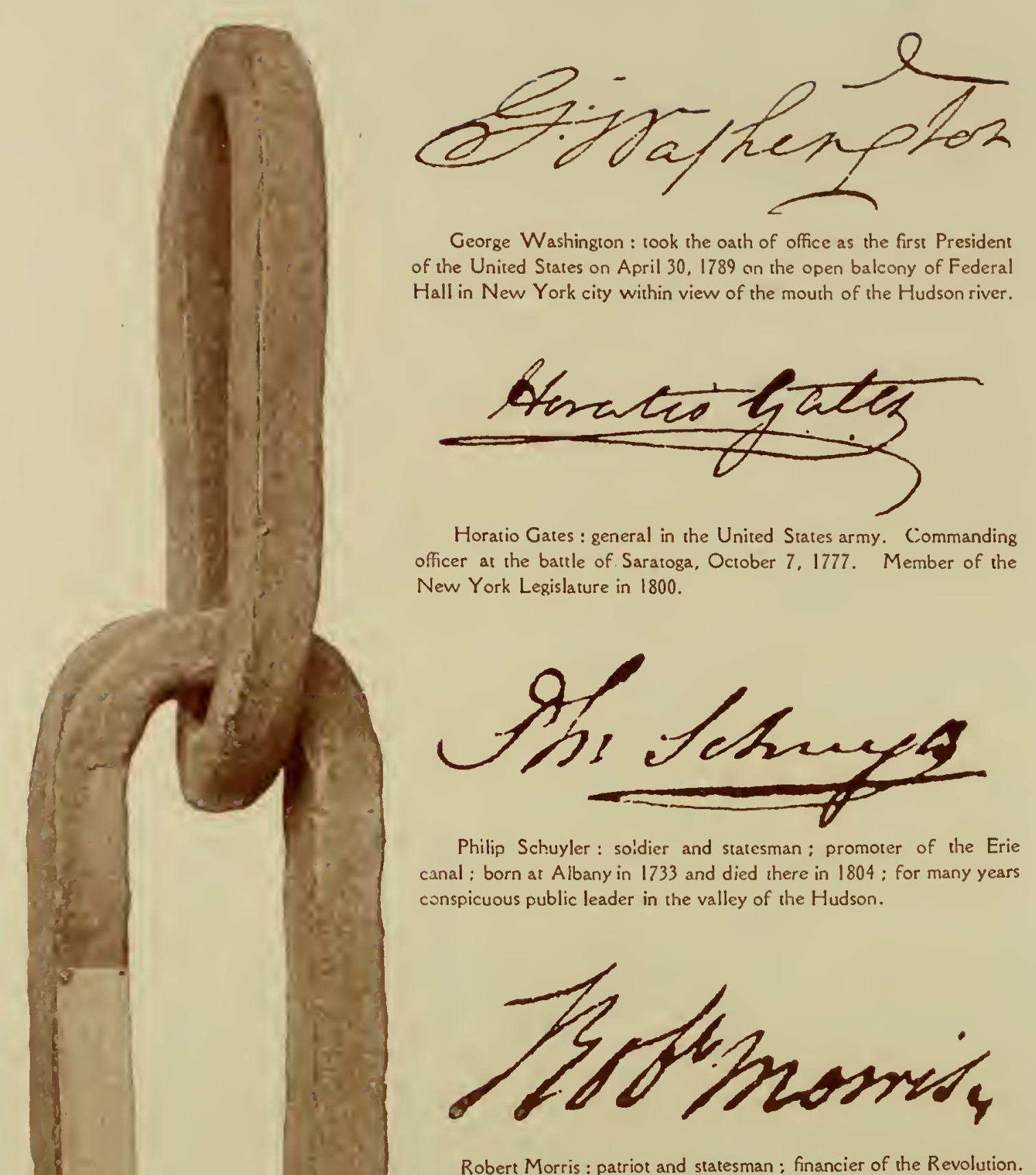

Robert Morris : patriot and statesman : financier of the Revolution.

Gown ofredunt servant Giokein traculey Gideon Hawley : first Superintendent of Common Schools in New York State and in the country ; elected January 14.1813: Secretary of
the Board of Regents; Regent of the University of the State of New York from 1842 to 1870.

Links of the great chain stretched across the Hudson river at West Point in 1778 to keep British war vessels a great grandson of the maker. The above autographs are reproduced from documents in the State Library.

31 


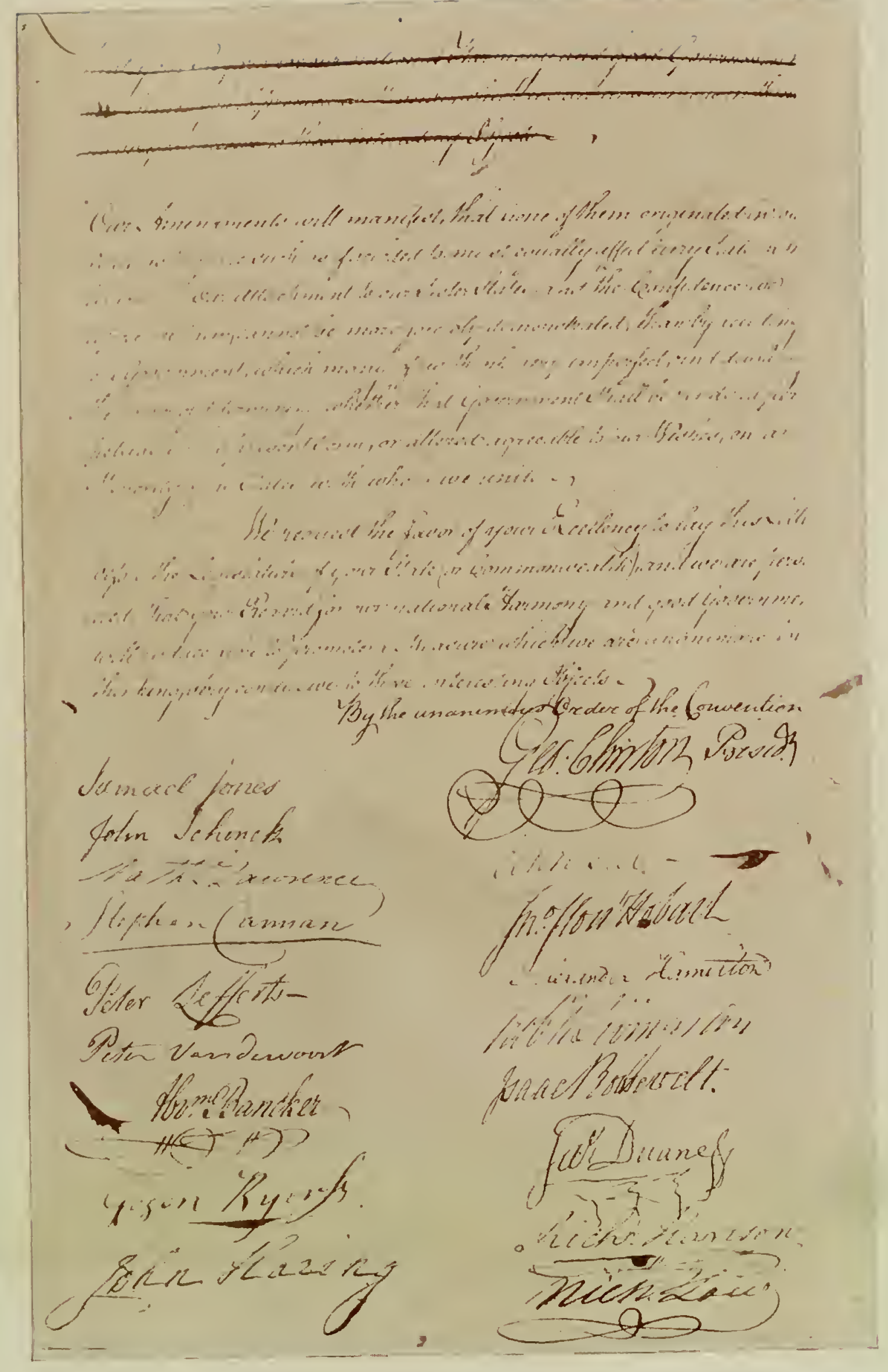

32 


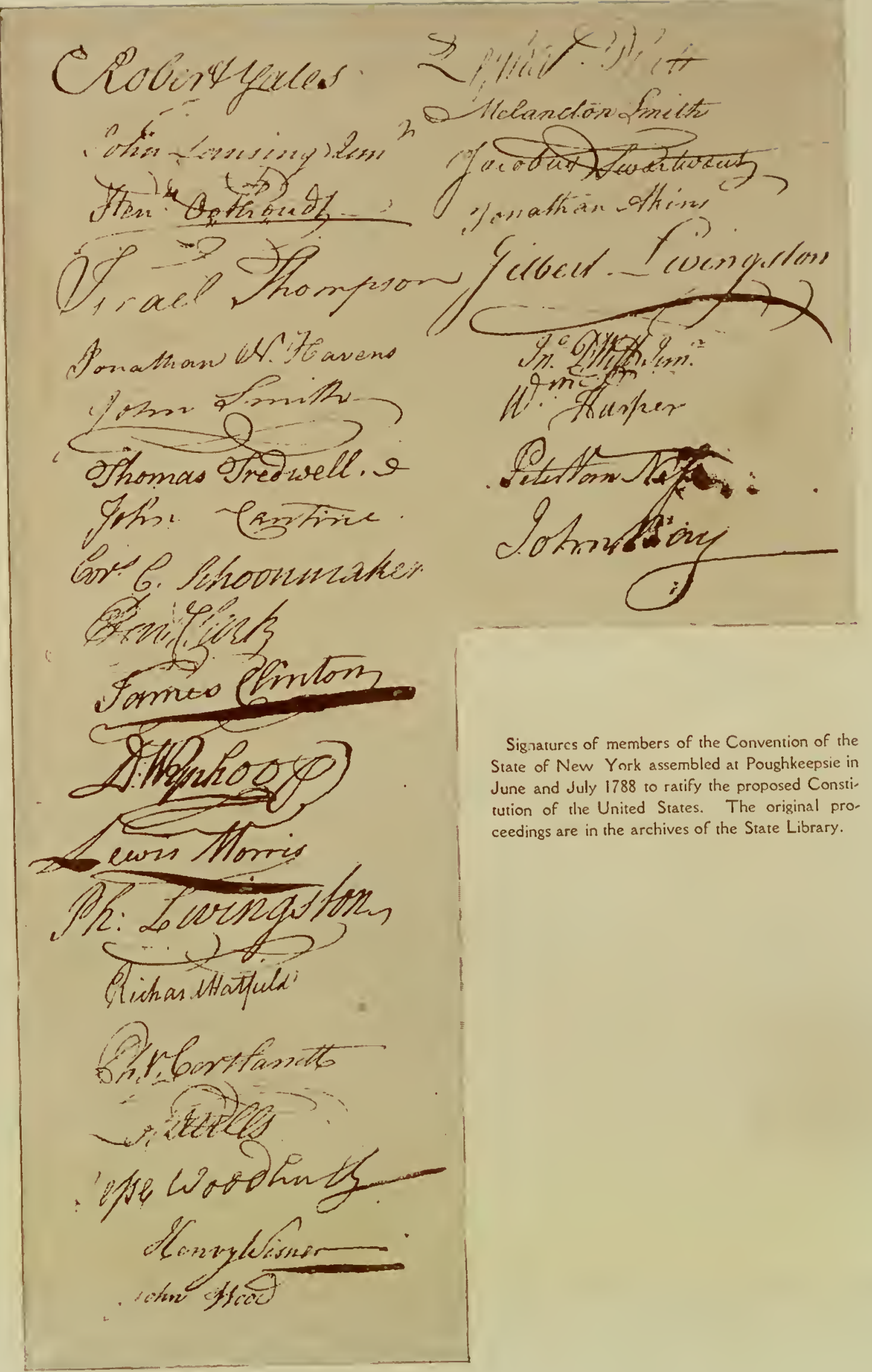


The tollewing teit centac2 he ramer ofak the

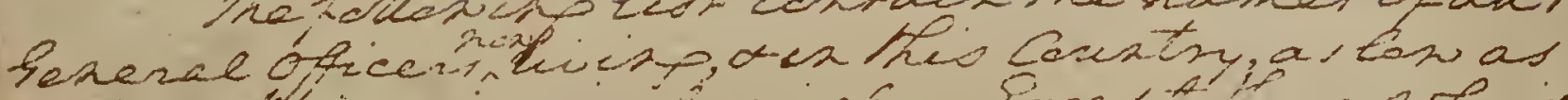

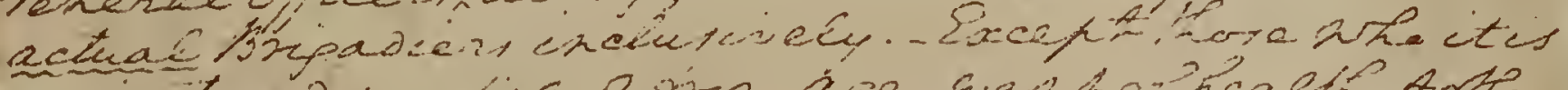

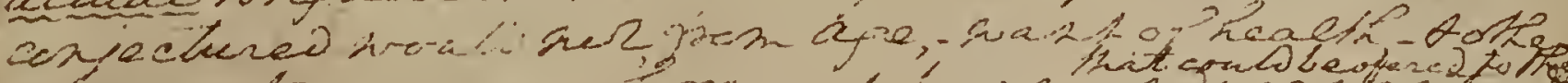

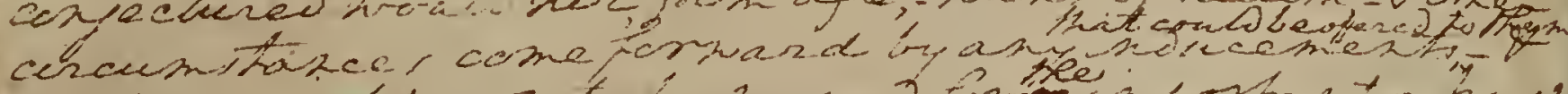

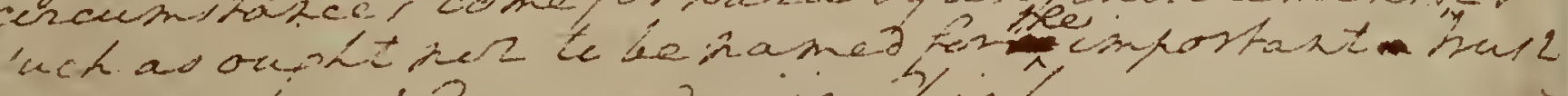

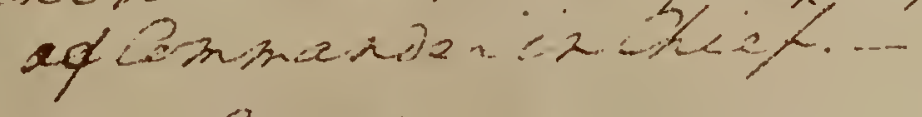

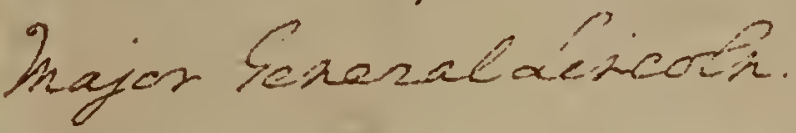

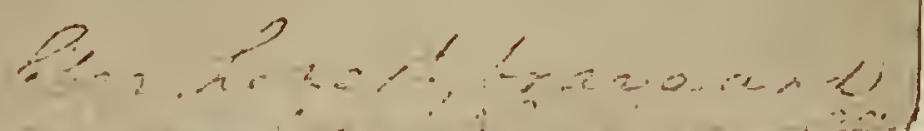

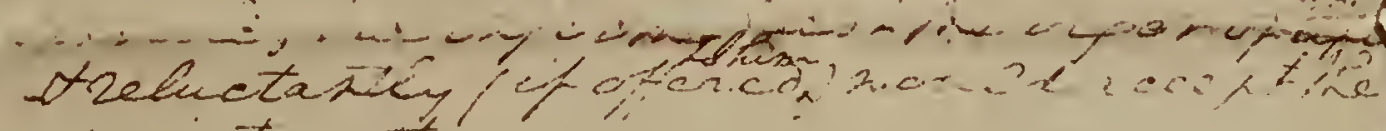

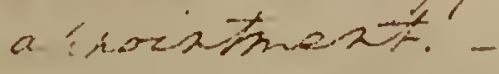

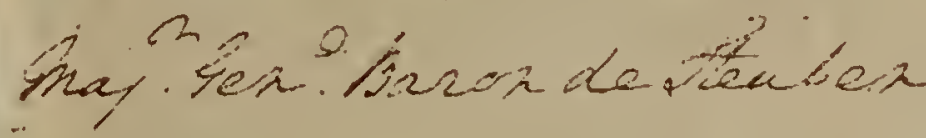

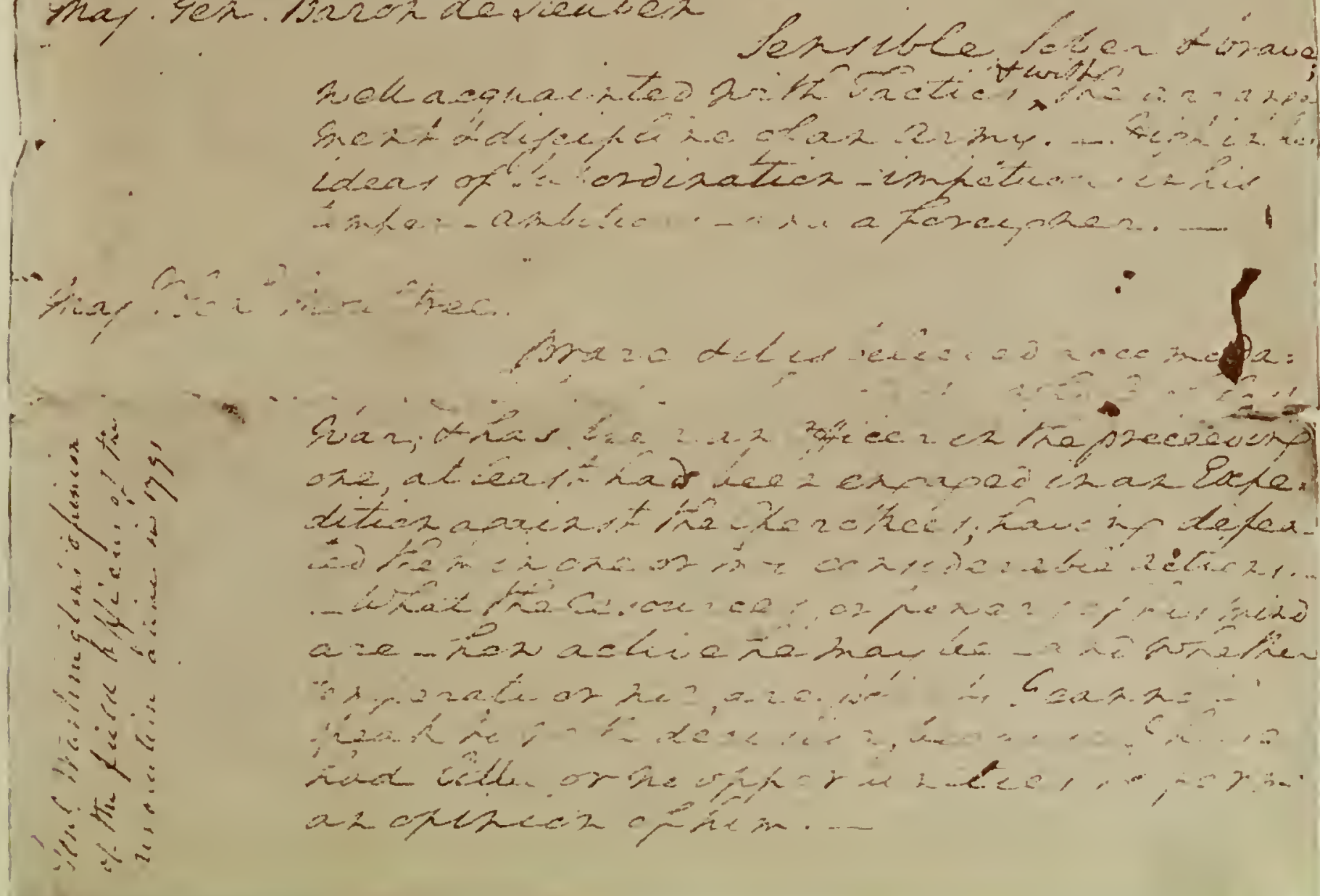

Washington's opinions of the surviving generals of the Revolution

The facsimiles show the first two pages of a paper prepared by Washington in the winter of 1791.72 after the defeat of Gen. Arthur St Clair by the Indians in the autumn of 1791 in Ohio, in anticipation of the necessity of appointing some one to succeed him in the command of the army. Twenty-three officers are mentioned in the series and Washington gives his opinion of the qualifications of sixteen of them for the office in question, 


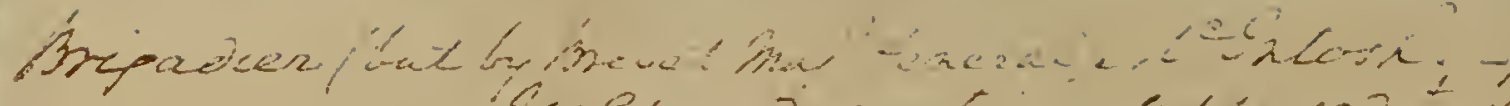

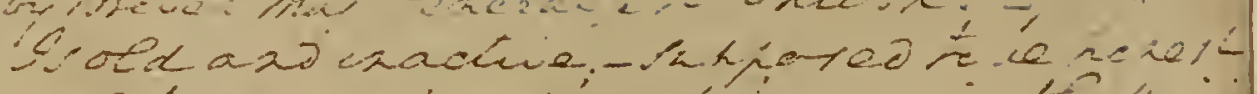

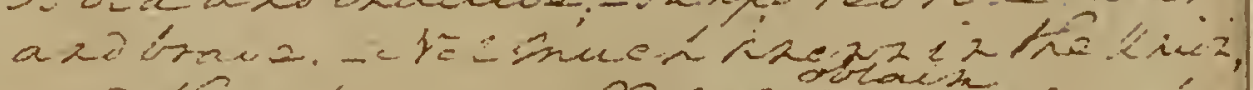

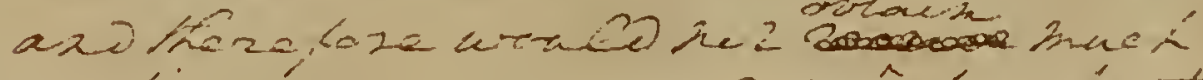
confidence, 02 moan muérpariect; - bifilar is ils cenmusity os bia rom.

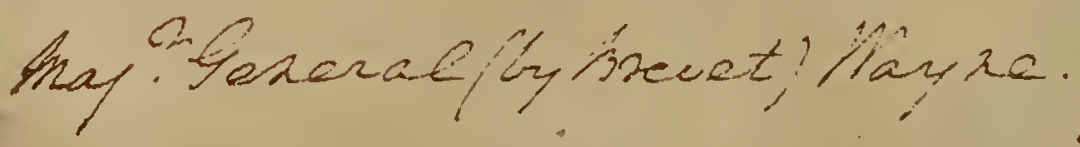

: inoreactiecateriz:

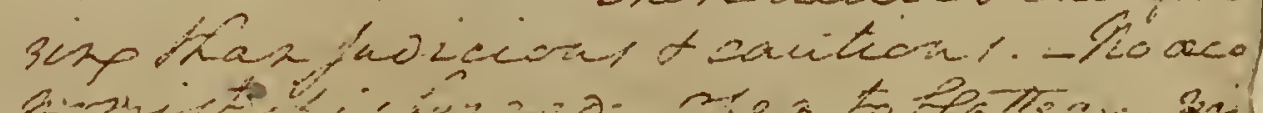

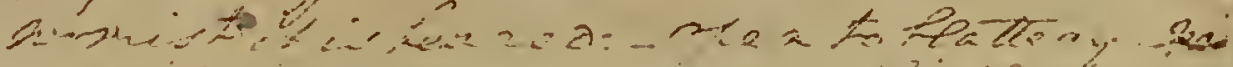

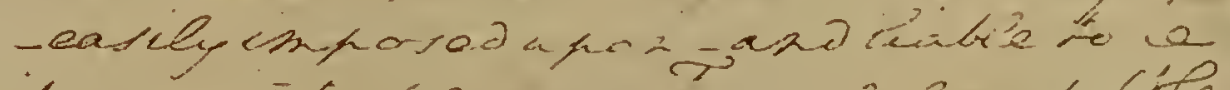

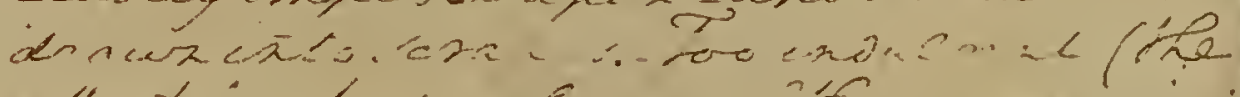

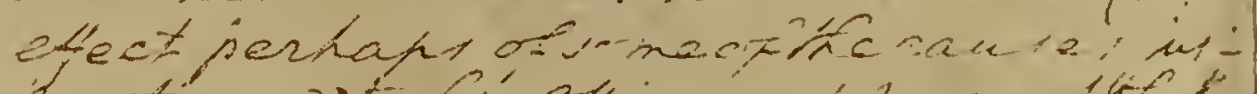

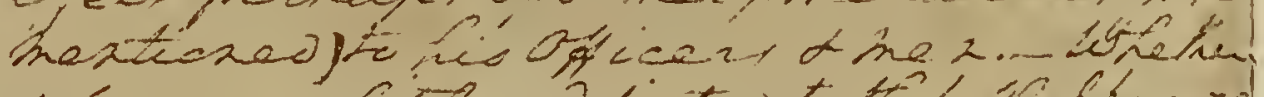

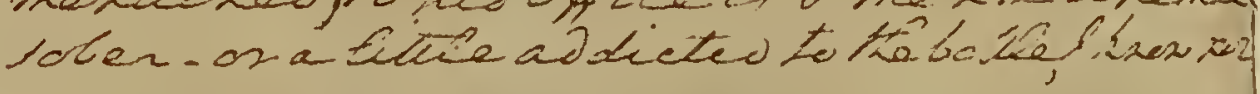

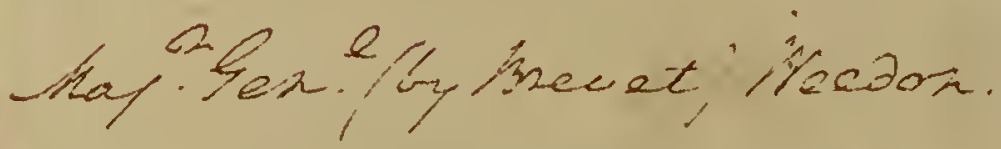

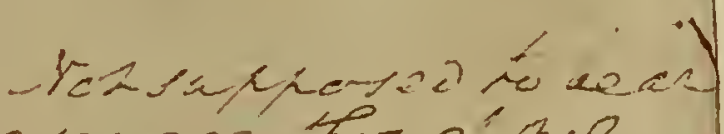

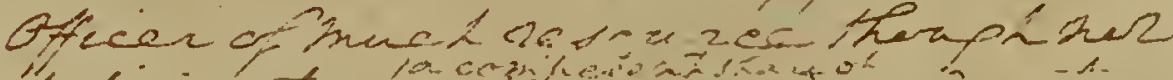

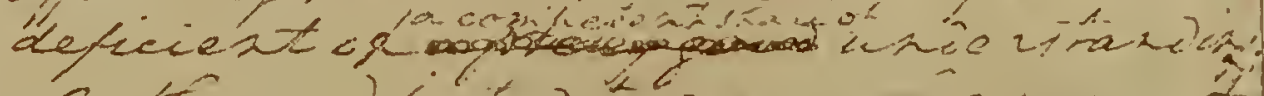

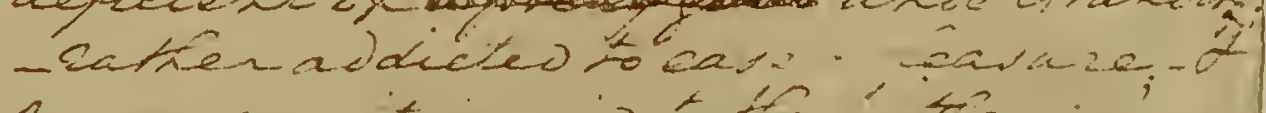

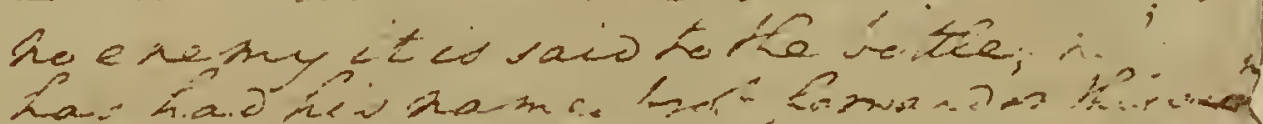

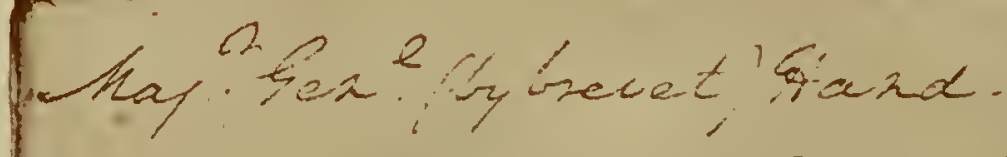

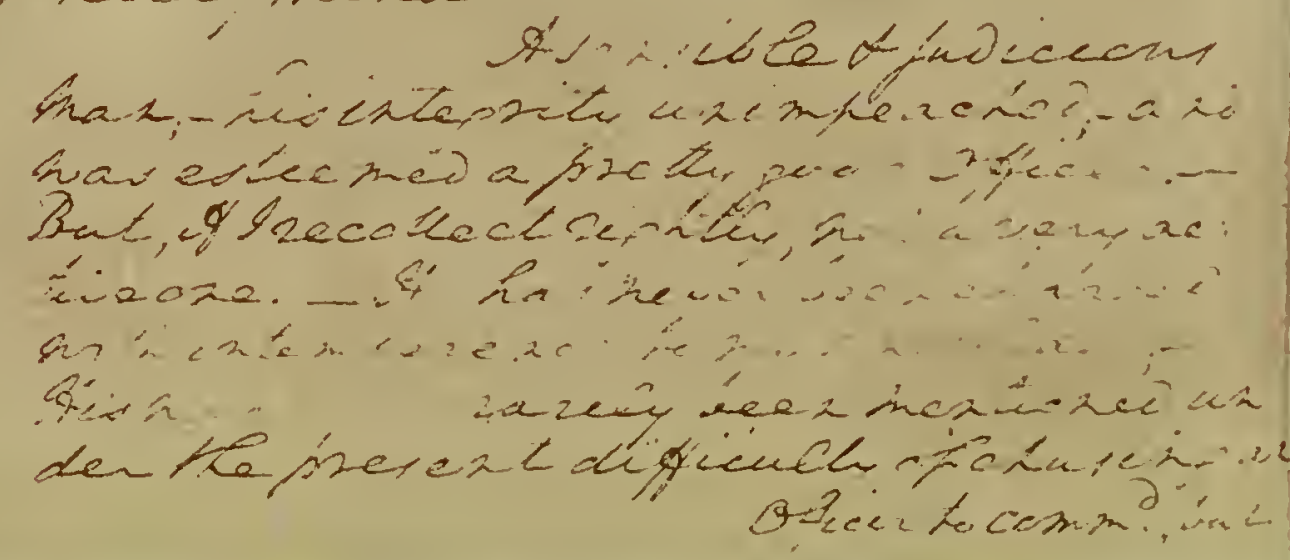

viz, of Generals Lincoln, Steuben. Moultrie. McIntosh, Wayne, Weeder, Hand, Scott, Huntington, Wilkinson, Gist, Irvine. Morgan, Putnam. Pinckney and Gov. H. Lee. This document with other Washington memorials in the State Library came into the possession of the State of New York by purchase from Mrs Ella Bossed Washington in 1871 .

35 


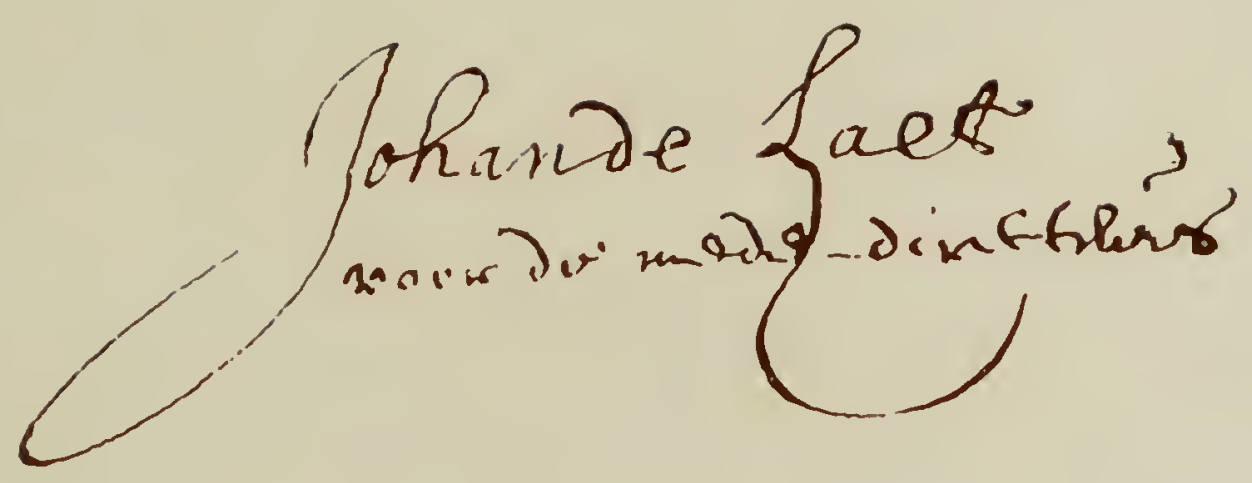

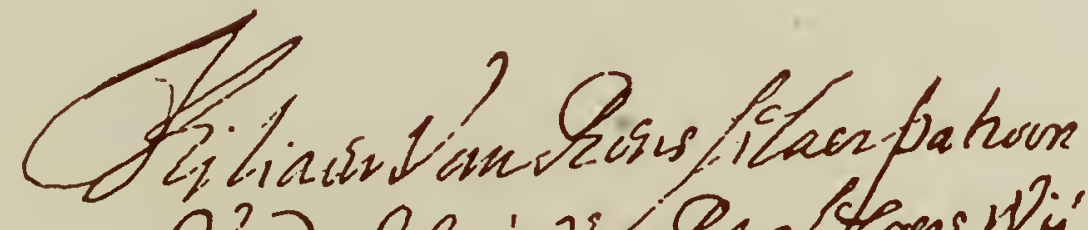

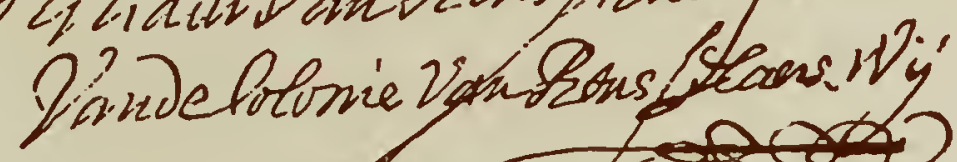

- Lam Rolants groor-
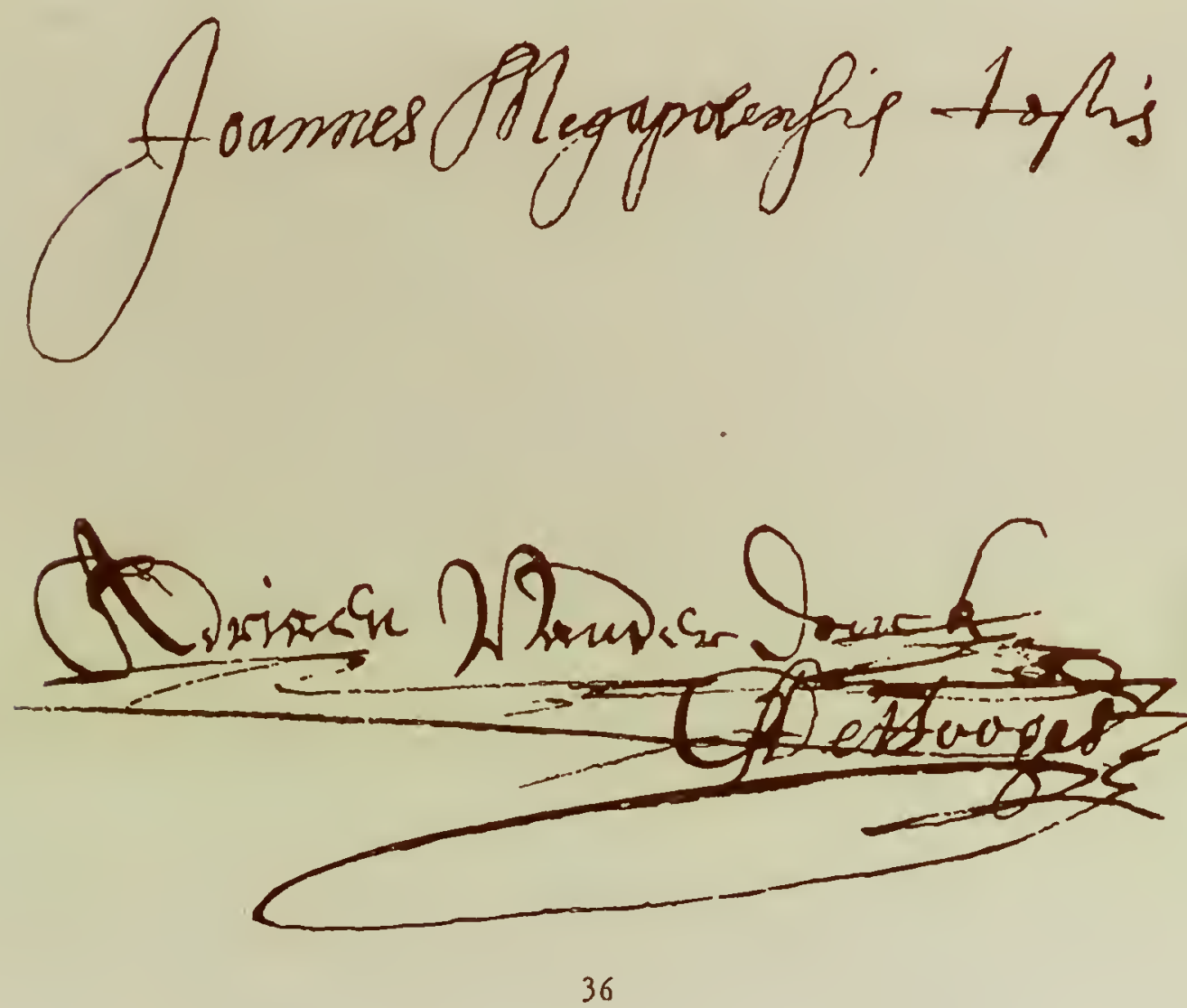
Peter. Trimuit Eurcektzour
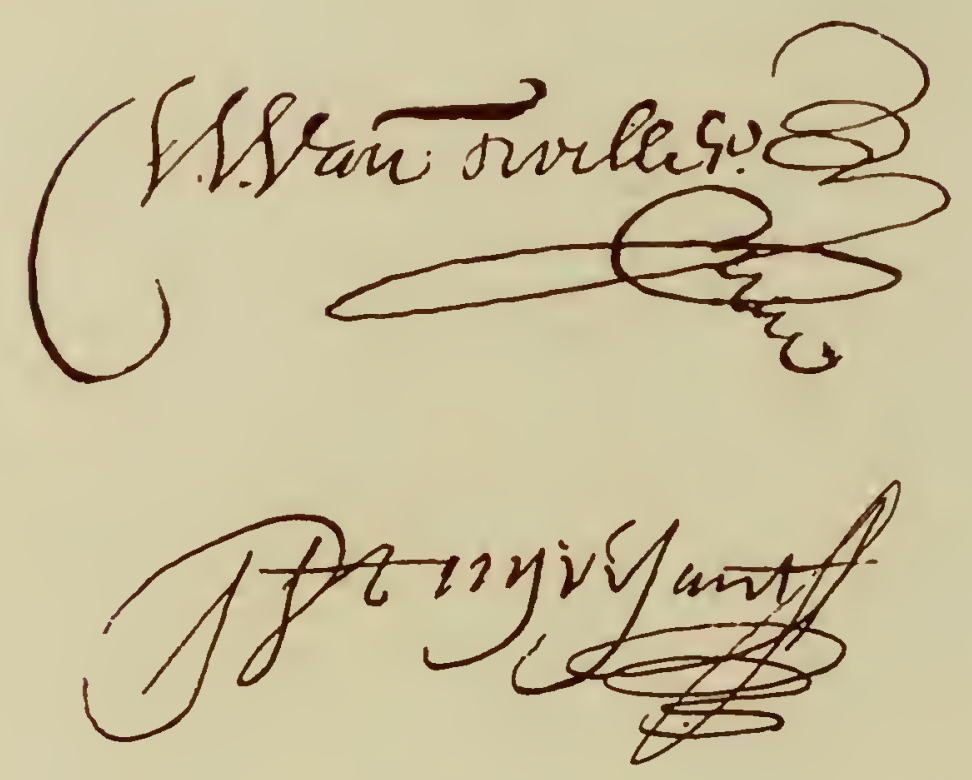

Ruhair Mecotts

The autographs on pages 36 and 37 are from original documents in the State Library. In the order of nit they are as follows

Johannes de Leet: author of dO Nietuwe Wiereldt. a scholarly work printed in 1625, which gives one of the earliest descriptions of New Netherland and the first full account of the Hudson river: a director of the Gerrit Swart, shout of the colony of Rensselaerswyck, May 8, 1652

Kiliaen $V_{a n}$ Rensselaer: first patroon of the colony of Rensselaerswyck. Taken from instructions to

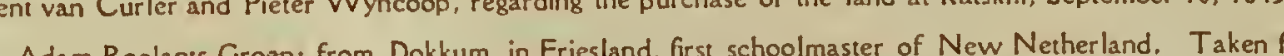

Adam Roelants Green: from Dokkum, in Friesland, first schoolmaster of New Netherland. Taken from
power of attorney to Jacob Tysen, to take charge of his children during his absence in the West Indies. December 4. 1649.

Johannes Megapolensis (Greek for Grootstadr): minister of the colony of Rensselaerswyck, 1642-49, and the first minister along the Hudson river outside of what is

Adrian van der Donck: schout, or sheriff, of the colony of Rensselaerswyck, 1641-46, afterwards a bold ampion of civic liberty and one of the leading opponents of Stuyvesant. Taken from an agreement to pay the
a signature.

Peter Minuit: Director General of New Netherland. Taken from the certificate of purchase from the Indians of land along the Delaware river, from Cape Henlopen to the mouth of the river, for the behoof of
Samuel Godyn and Samuel Blommaert, both directors of the Dutch West India Company, dated July 15, 1630 . Wouter van Twilled: Director General of New Netherland. 1633.38. Taken from $\Delta$ contract with orge Rapaelie, respecting the use of iwo cows, June 4, 1638.

Peter Stuyvesant: Director General of New Netherland, 1647-64. Taken from a pass to Jeremias van r, the third son of the first patroon, to sail to Holland in the ship "Beaver." October 28, 1655. Richard Nicolls: first English governor of the Province of New York. Taken from agreement with the 7, 1665 .

37 


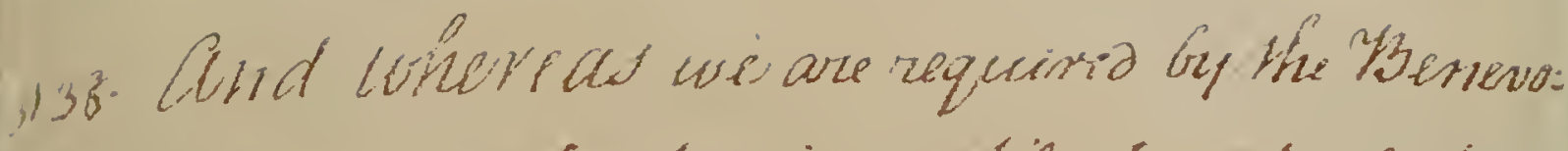
- Ant Wrincipuses of rational ale orly not only to expert civil Syranrly but also to guard against that Furituas offorefoion \& Intorierasce co how:

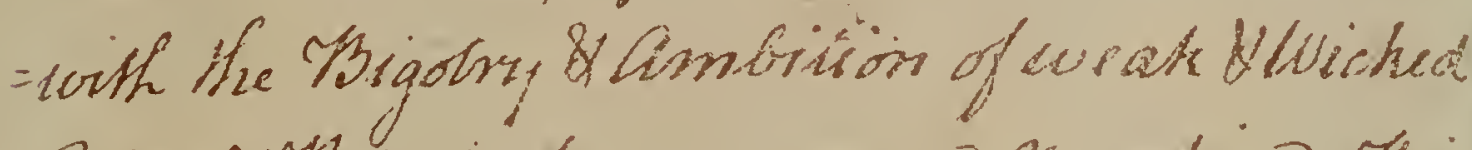

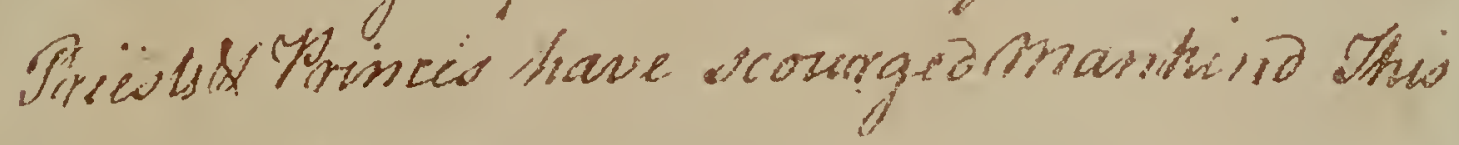
bowen nation doth further in the wine arid by-

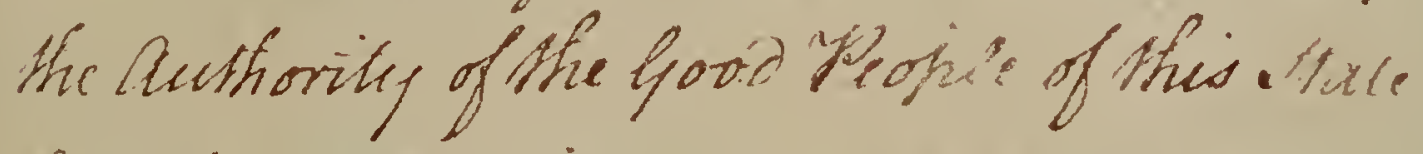
Ordain determine and desforte that in e Exerecio kinjoymont

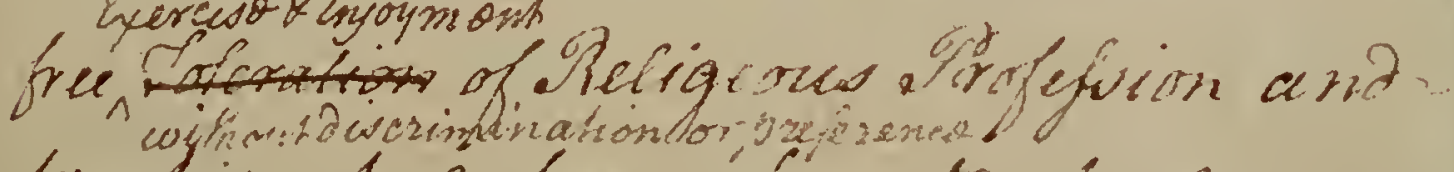
Worships, shale forever houafier is alfred within His. Slain to ali mankiric. Provided

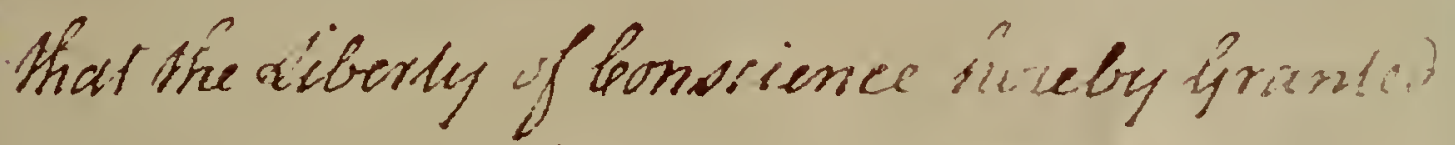
shall not is ac forisinued as to cosceuse its of licencionusucfs, or justify. Practices inconsis. - tart with the Peace or "agile, of lin. Plate.

Religious freedom made the earliest progress in New York because it was the necessity of a mixed population. It is reconsized in the early charters, and in the instructions to the governors, both Dutch and English. The Dutch exacted and the English General Assembly of the colony, in New York city in 1683, was undoubtedly the first Legislature in the world to put the pledge of complete religious freedom into a written constitution. The first Constitution of the State, framed in 1777, on the very firing and in the 38 th article for absolute religious toleration. The 38 th article is here reproduced from the original document in the State Library.

38 


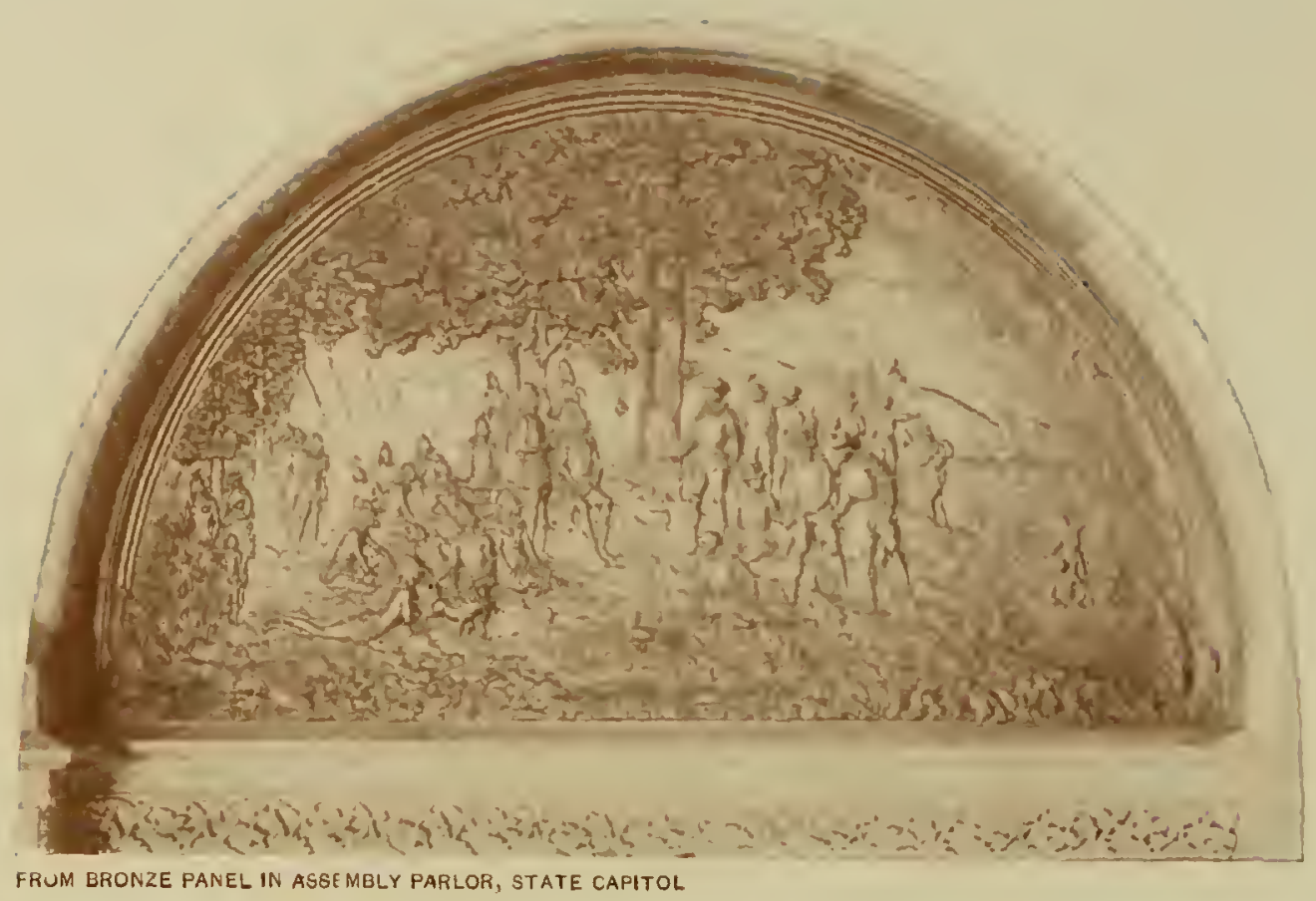

Hudson trading with the Manhattoes

\section{THE BIRTH OF THE HUDSON \\ $*$}

$\mathrm{N}^{\mathrm{A}}$

ATURE did not just happen to make the Hudson river and leave it for the Dutchmen to find. Its lines were laid down far in the remote past of the earth and it had long passed the climax of its greatness and its beauty before the Half Moon's keel had turned its waters. As the French came in from the north along the lines of great wounds in the earth's crust, the St Lawrence and the Champlain valleys, so the Hudson valley represents another such rupture in the rocks, where the outflowing land waters, finding the line of least resistance, made this their path to the sea. This ancient day dates back to the time when the great Appalachian mountain system began to form by the folding up of the rocks under the shove and stress of the weight of Atlantic ocean waters. This irresistible force from the sea, pressing the soft limestones, shales and sandstones of the eastern continent border against the stiff unyielding granites which compose the Canadian shield, twisted and folded the more yielding strata or broke them asunder and pushed them in great masses over each other. And in this way the belt of country occupied by this great Hudson valley was broken down to a line of crushed and downfallen rocks which is still a line of foreboding weakness in the structure of our continent. On every hand its ancient scars are to be seen, though most of them lie buried beneath the waters of the river. Today the great river is half drowned by the waters of the ocean. 
It is in fact an estuary from Albany southward, the sandbars near its mouth are the overslaughs below Castleton which have obstructed navigation from the days of the Dutchmen to this day. At exceptionally high tides or in long drought the salt water wedges in under the fresh almost as far north as the city of Hudson. The low and rounded valley from Albany northward has for long, long ages been the seat of shallow waters, often spreading out into extensive lakes, and what is commonly termed the Upper Hudson is only the accessory headwaters of what was once a majestic trunk stream. Southward the river hugs its ancient deep cut channel, the more as it gets closer in between the steep walls of the Highlands, and even though it spreads out at places still farther south, there it lies upon and buries its ancient banks.

In one of the later phases of the river's history the continent stood far higher above the sea than it does today and the valley ran 100 miles out beyond the point of Manhattan island. Then its waters, passing in tremendous volume through a majestic gorge which they had themselves cut out, projected themselves over the now buried edge of the continent into the waters of the Atlantic in a stupendous cataract, just as, on an infinitely smaller scale, the waters of the Montmorency precipitate themselves over the cliffs below Quebec into the St Lawrence river. Then the earth's crust in this region began one of those rhythmic oscillations which carry it up or down in obedience to physical laws still unexplained, and continued till the lower reaches of the ancient valley were slowly carried down beneath the ocean level and the sea rushed in to take the place where the fresh waters had flowed so long and freely.

If the Half Moon had arrived on its voyage of discovery in the year 1609 of the Postglacial period its skipper would have tied up far out beyond the outermost reaches of New York bay and beheld the amazing spectacle of this outpouring tide of the river precipitating itself over the edge of the continent and there he must have rested, excluded from all entrance to the river above his head. The way was not yet open, the flood gates not yet let down. Far up the stream from the Highlands down, the river was flowing through a profound gorge in the rocks a thousand feet deeper than at the Highlands today. There where the engineers are now trying to carry a gigantic aqueduct beneath the river from the west shore to the east, no rock bottom to the canyon has yet been found at a depth of more than 600 feet beneath the present bottom of the stream.

All this elevated stream must be depressed to let the Dutchmen in and the earth was not yet prepared for the opening of this passage into its western lands. Indeed there was no Dutchman about in those days. 
To the same ultimate causes which gave birth to the St Lawrence river and Lake Champlain is due the valley of the Hudson, but the course of its history has been somewhat different though not more varied than theirs. Once when the glacial ice stood over the St Lawrence and blocked the flow of its waters all the drainage from the Great Lakes flowed out into New York bay by way of the Mohawk and to the greater volume of this stream we owe the rounded slopes of the upper valley and the deeper gorges of the lower.

As the valley became the scene of human history the commanding highlands of the narrow thoroughfare were found to be the natural military key to the control of the country north and south and when issues were joined between one party in control of the northern region and another in possession of the southern, whether between French and British or between the colonists and the English, it was inevitable that those issues should have been fought to their solution where the waterways at the north controlled by the one opened out into the lands about the head of the waterway controlled by the other.

In the contour and altitude of crag and hill, the rock-directed course of the streams, the retreats of shores, the jutting headlands and islands, whose shapes are due to the geological forces which acted on them, are to be found the unconscious guiding influences in the development of the train of human events in this region so pregnant with large records on the pages of our history.

John M. Clarke

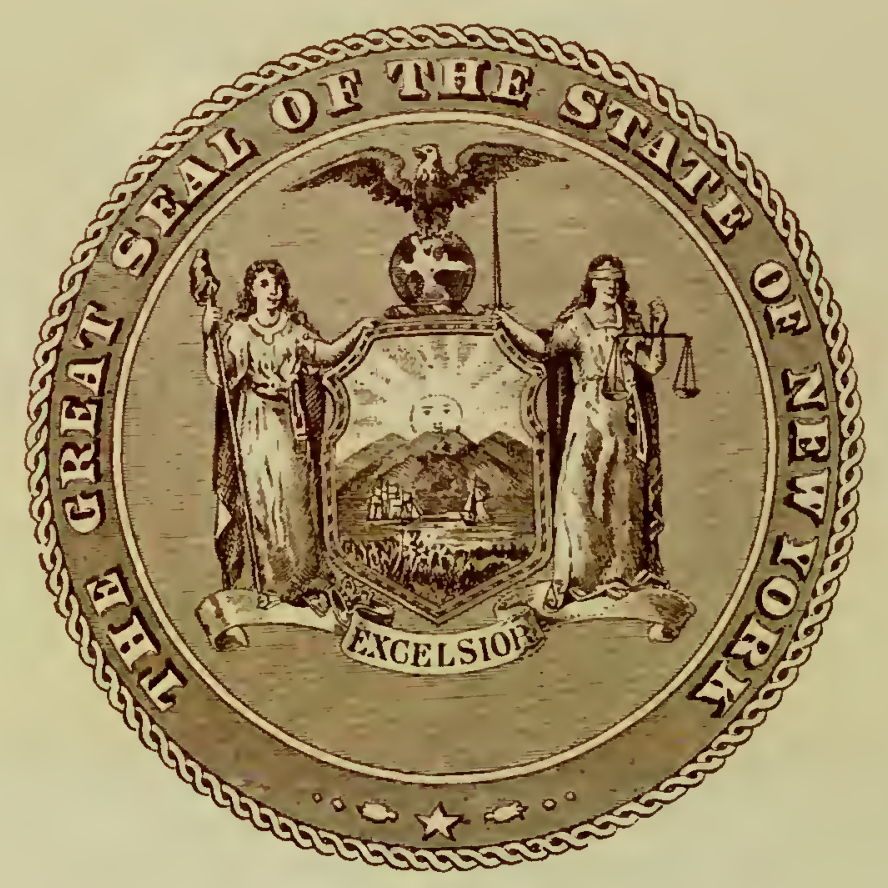




\section{A SCENE ON THE BANKS OF THE HUDSON}

\section{*}

OOL shades and dews are round my way,

$\checkmark$ And silence of the early day;

Mid the dark rocks that watch his bed,

Glitters the mighty Hudson spread,

Unrippled, save by drops that fall

From shrubs that fringe his mountain wall:

And o'er the clear still water swells

The music of the Sabbath bells.

All, save this little nook of land,

Circled with trees, on which I stand;

All, save that line of hills which lie

Suspended in the mimic sky, -

Seems a blue void, above, below.

Through which the white clouds come and go:

And from the green world's farthest steep

I gaze into the airy deep.

Loveliest of lovely things are they,

On earth, that soonest pass away.

The rose that lives its little hour

Is prized beyond the sculptured flower.

Even love, long tried and cherished long,

Becomes more tender and more strong.

At thought of that insatiate grave

From which its yearnings cannot save.

River I in this still hour thou hast

Too much of heaven on earth to last :

Nor long may thy still waters lie,

An image of the glorious sky.

Thy fate and mine are not repose,

And ere another evening close,

Thou to thy tides shalt turn again,

And I to seek the crowd of men.

William Cullen Bryant

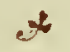

The Catskills to the northward rise,

With massive swell and towering crest, -

The old-time "mountains of the skys,"

The threshold of eternal rest I

Wallace Bruce 


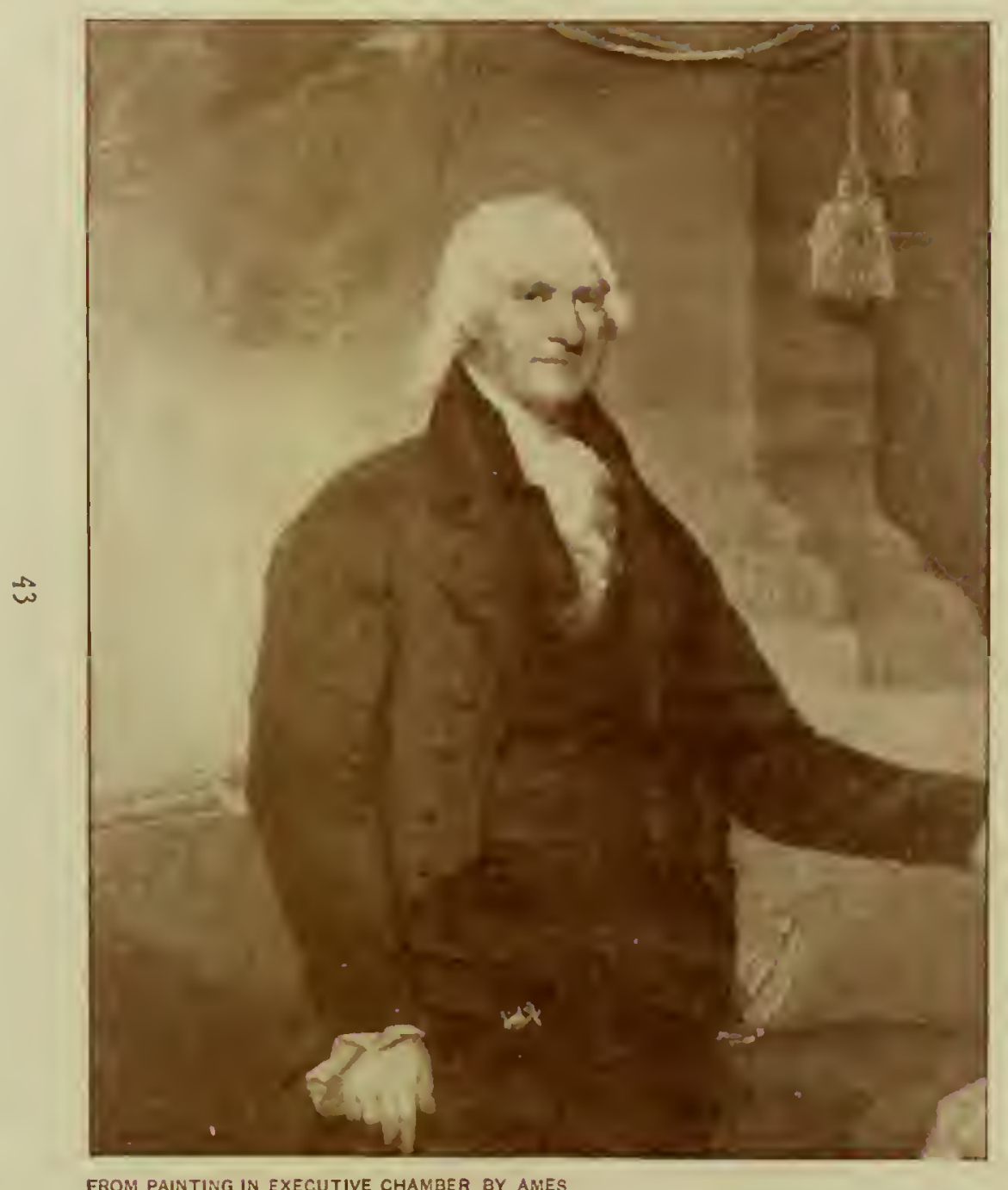

FROM PAINTING IN EXECUTIVE CHAMBER OY AMES

George Clinton The first Governor

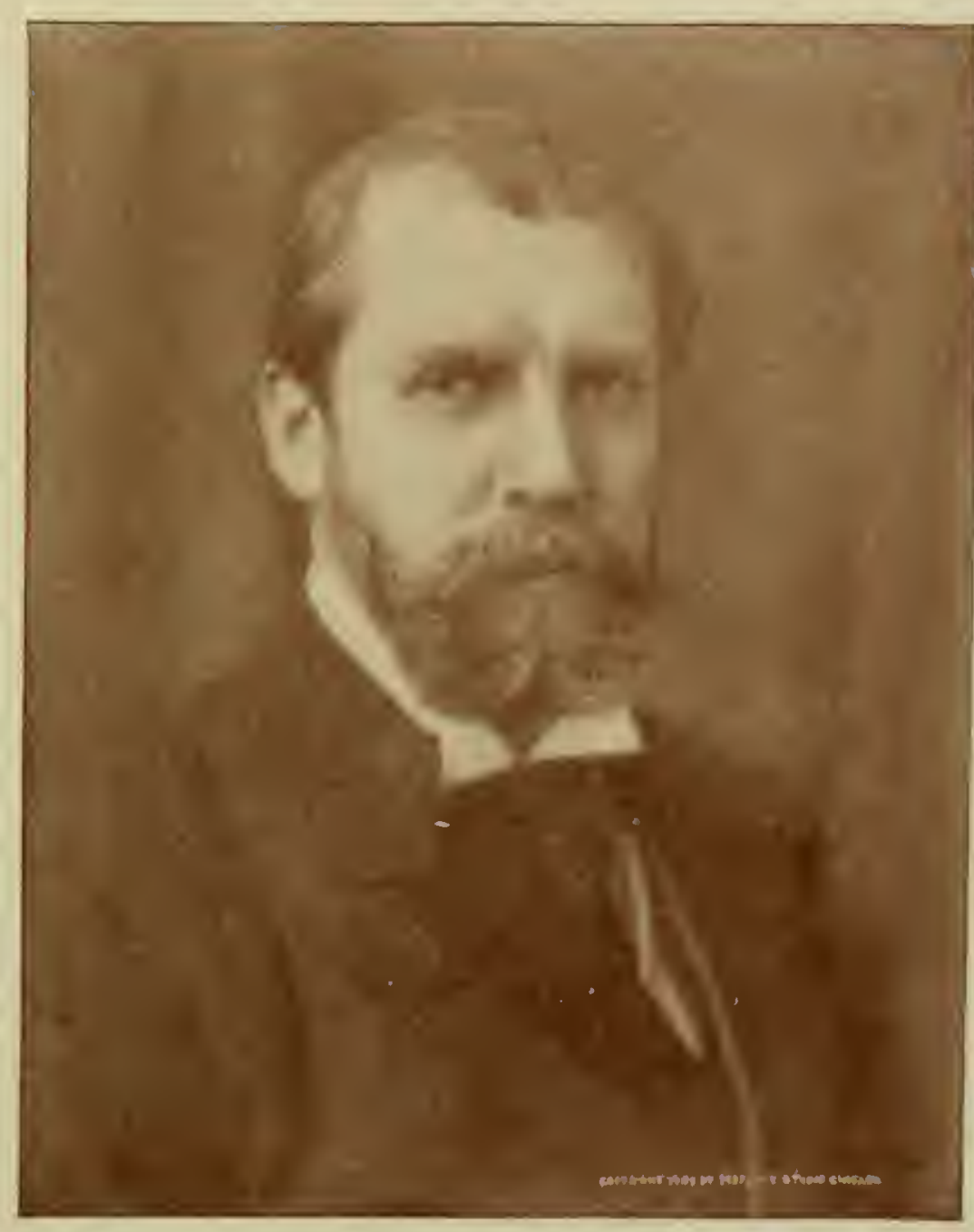

Charles E. Hughes The present Governor 
AUTOGRAPHS OF GOVERNORS OF NEW YORK STATE
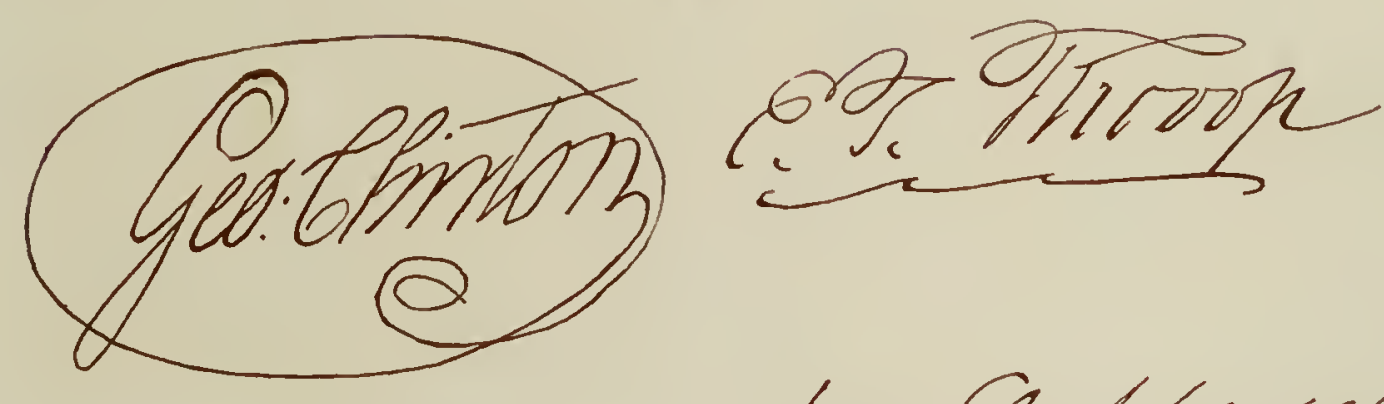

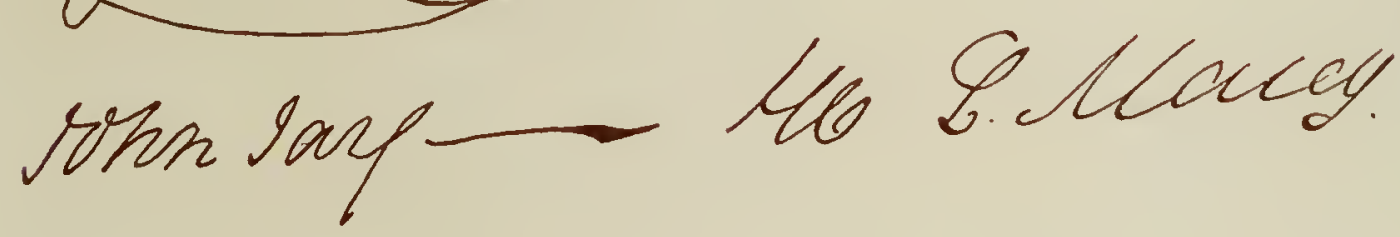

Horganfeivis Niclian $1 \%$ Sewing.

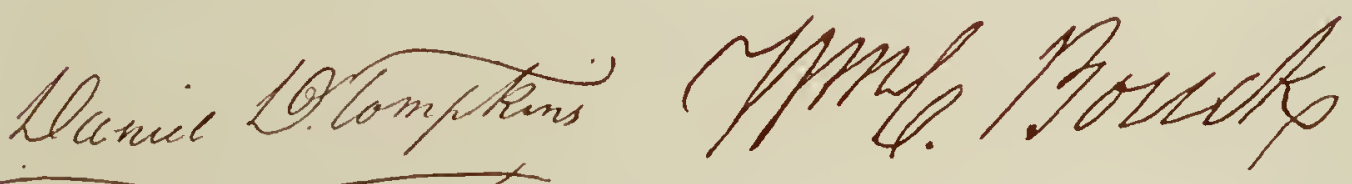

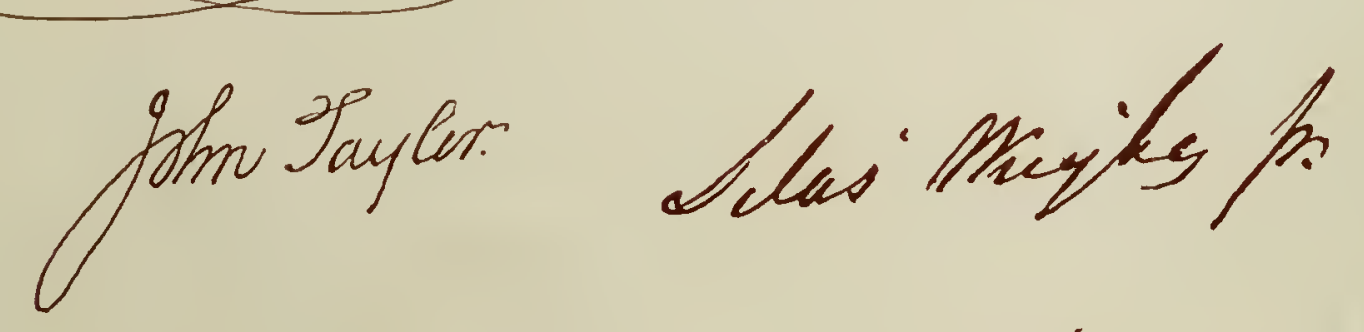

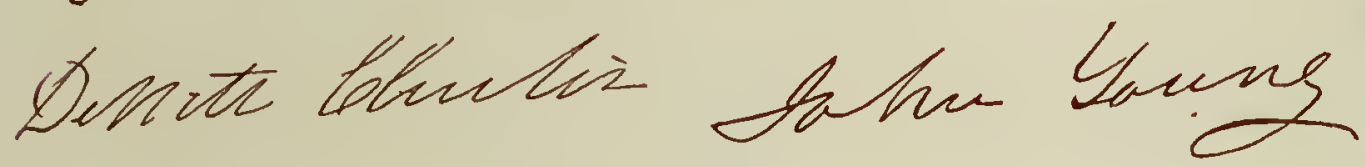

Posph \& Coateo

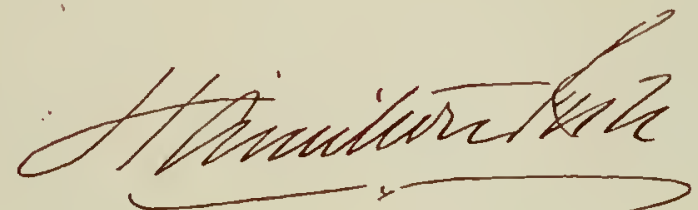

Clastre Pitchers

Waskugton Sint)

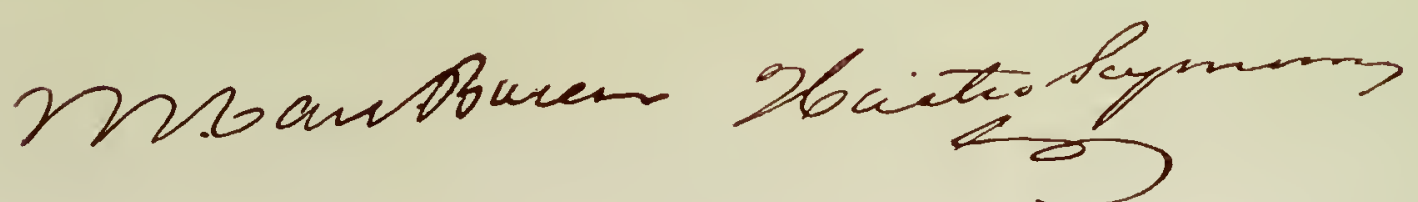

44 


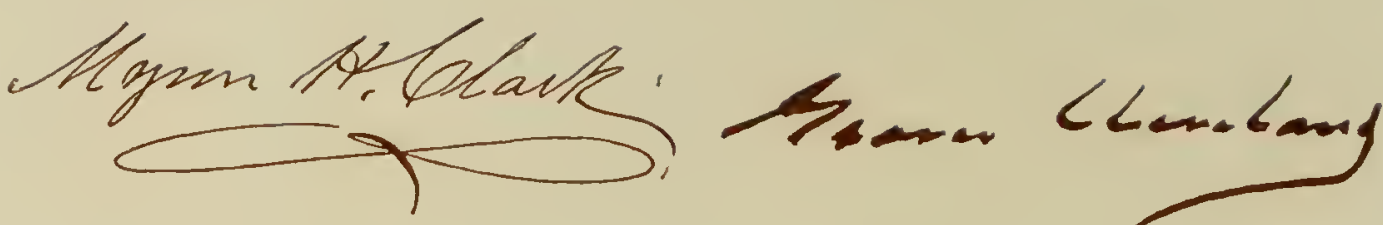

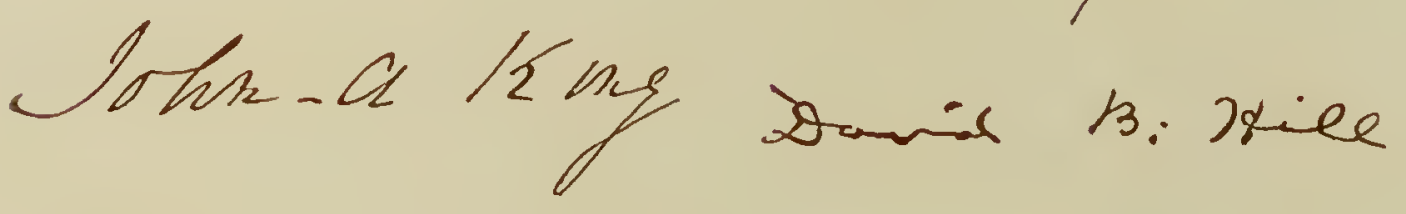
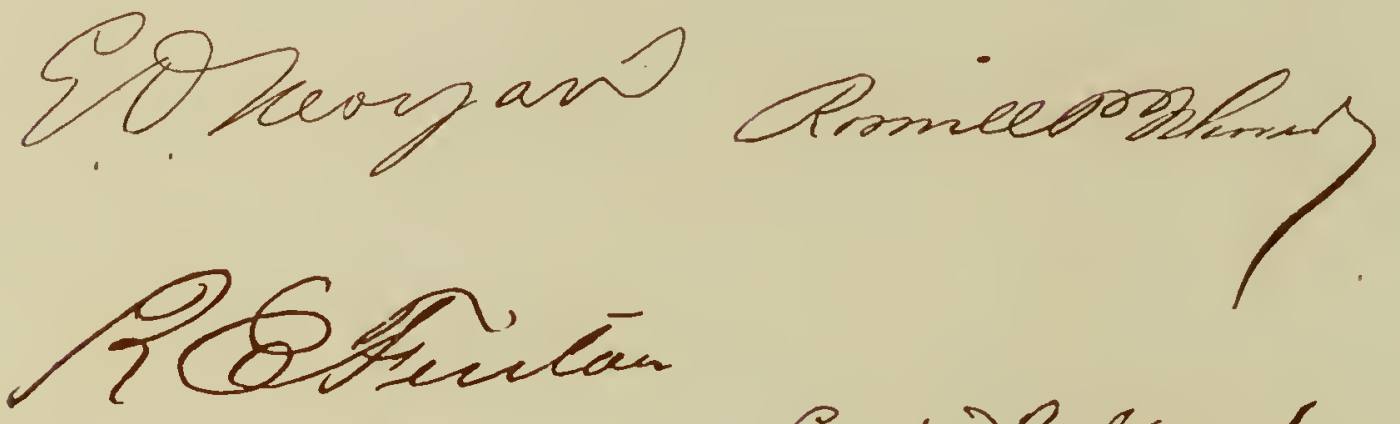

Sesi Y. Hatros

Qmongsymace

Fruna Alseack

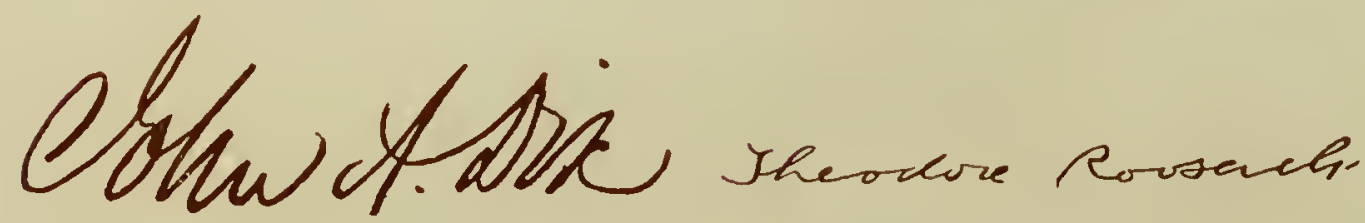

Samuetsiden B.3.Sace

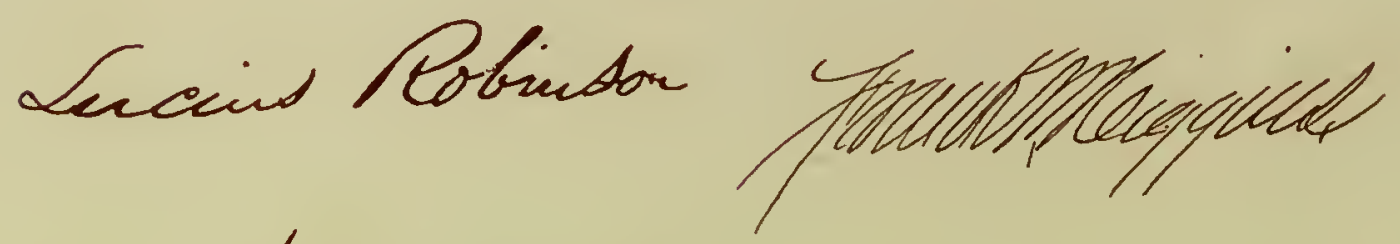

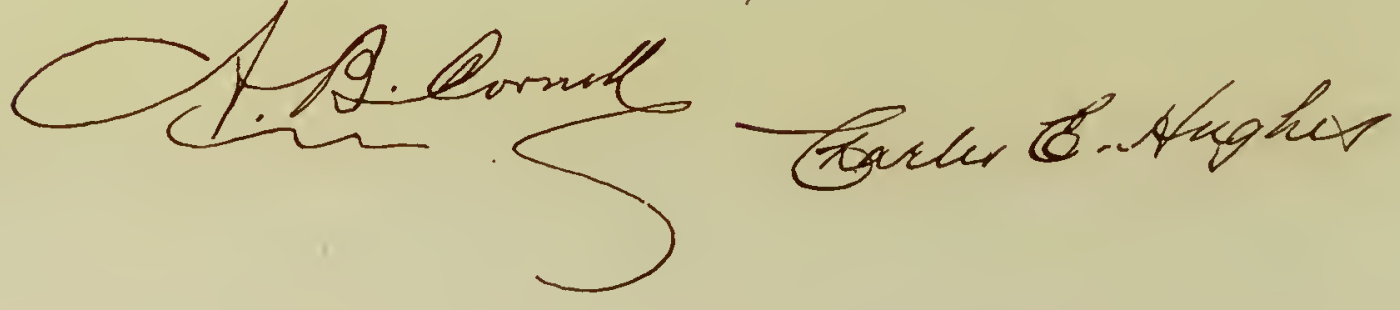

45 


\section{CATSKILL MOUNTAINS}

\section{2}

ND, lo! the Catskills print the distant sky,

1 And o'er their airy tops the faint clouds driven,

So softly blending, that the cheated eye

Forgets or which is earth or which is heaven, -

Sometimes, like thunder-clouds, they shade the even,

Till, as you nearer draw, each wooded height

Puts off the azure hues by distance given :

And slowly break upon the enamored sight,

Ravine, crag, fieid, and wood, in colors true and bright.

Mount to the cloud-kissed summit. Far below

Spreads the vast champaign like a shoreless sea.

Mark yonder narrow streamlet feebly flow.

Like idle brook that creeps ingloriously;

Can that the lovely, lordly Hudson be,

Stealing by town and mountain? Who beholds,

At break of day, this scene, when, silently,

Its map of field, wood, hamlet, is unrolled,

While, in the east, the sun uprears his locks of gold,

Tili earth receive him never can forget,

Even when returned amid the city's roar,

The fairy vision haunts his memory yet,

As in the sailor's fancy shines the shore.

Imagination cons the moment o'er,

When first-discovered, awe-struck and amazed,

Scarce loftier Jove-whom men and gods adore-

On the extended earth beneath him gazed,

Temple, and tower, and town, by human insect raised.

Blow, scented gale, the snowy canvas swell,

And flow, thou silver, eddying current, on.

Grieve we to bid each lovely point farewe!l,

That, ere its graces half are seen, is gone.

By woody bluff we steal, by leaning lawn,

By palace, village, cot, a sweet surprise,

At every turn the vision breaks upon;

Till to our wondering and uplifted eyes

The highland rocks and hills in solemn giandeur rise.

* $\%$ *

Theodore S. Fuy 


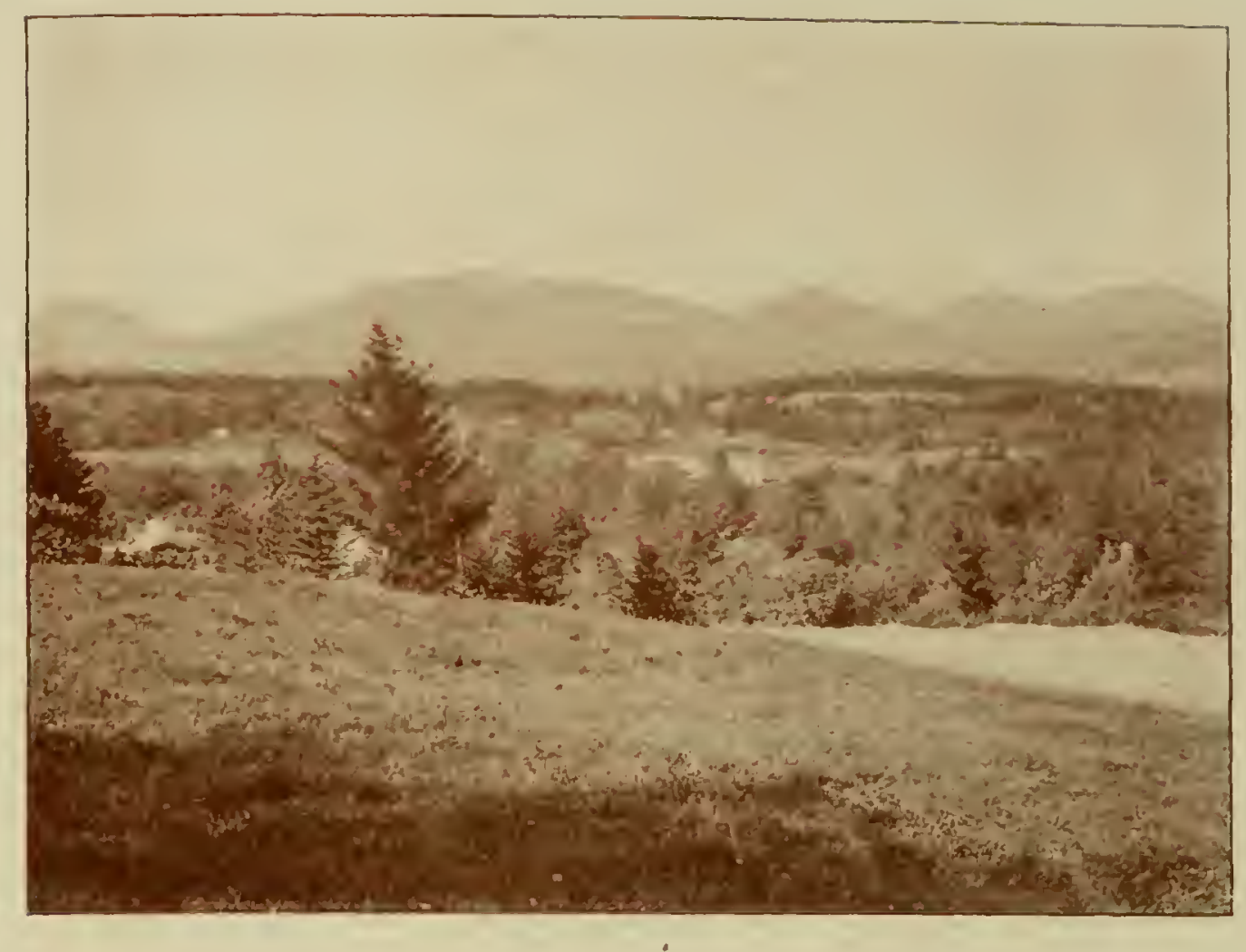

\section{THE HUDSON}

\section{*}

1 WAS a vision of childhood that came with its dawn, Ere the curtain that covered life's day-star was drawn; The nurse told the tale when the shadows grew long, And the mother's soft lullaby breathed it in song.

"There flows a fair stream by the hills of the west,"She sang to her boy as he lay on her breast ;

"Along its smooth margin thy fathers have played; Beside its deep waters their ashes are laid."

I wandered afar from the land of my birth, I saw the old rivers, renowned upon earth, But fancy still painted that wide-flowing stream With the many-hued pencil of infancy's dream.

I saw the green banks of the castle-crowned Rhine,

Where the grapes drink the moonlight and change it to wine; I stood by the Avon, whose waves as they glide Still whisper his glory who sleeps at their side.

But my heart would still yearn for the sound of the waves That sing as they flow by my forefathers' graves: If manhood yet honors my cheek with a tear, I care not who sees it,- - no blush for it here!

Farewell to the deep-bosomed stream of the West I I fling this loose blossom to float on its breast :

Nor let the dear love of its children grow cold, Till the channel is dry where its waters have rolled! 


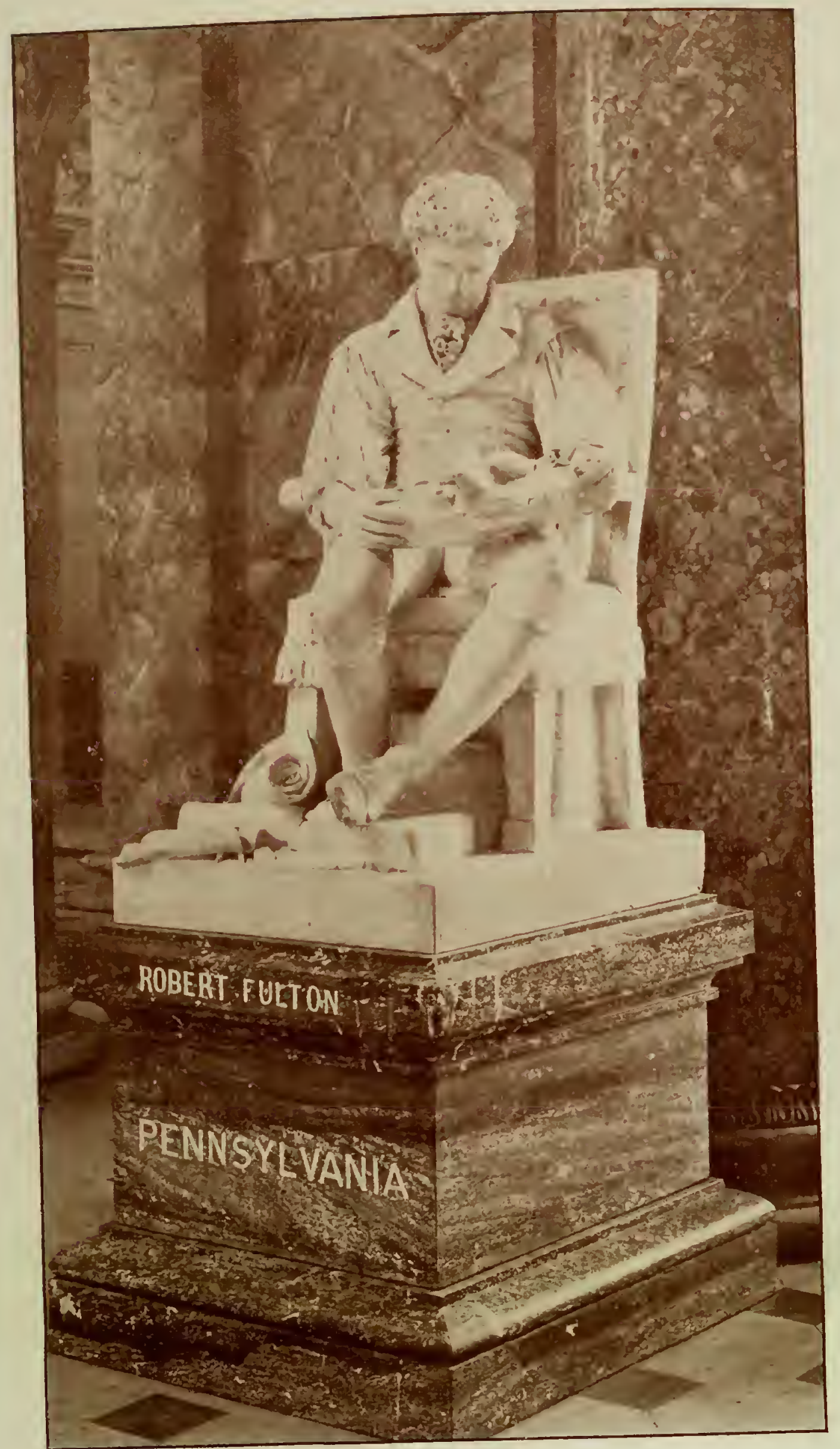

Statue of Fulton in the Capitol at Washington 


\title{
FULTON AND THE CLERMONT
}

\author{
$*$ \\ $M^{\circ}$ \\ ORE than a century ago, an English poet, Erasmus Darwin, \\ the grandfather of the illustrious scientist, Charles Darwin, \\ made this prophecy:
}

\section{Soon shall thy arm, unconquered steam, afar Drag the slow barge, or drive the rapid car ; Or, on wide-waving wings expanded, bear The flying chariot through the fields of air.}

It was generally thought that this verse was the product of a disordered imagination, but its predictions have all been fulfilled. In 1807 Robert Fulton solved the problem of steam navigation; in 1827 Robert Stevenson built the first steam locomotive; and in 1909 the Wright brothers and others with their aeroplanes are subduing the air. There have been innumerable inventions, and a vast multitude of inventors: but the great inventors, they who have revolutionized scientific processes or made new application of the forces of nature to the progress of mankind, have been very few. Of these Robert Fulton was eminently one. He was a mechanical genius of the highest order, as he was also a rarely gifted man in various lines of achievement. His enduring fame, however, rests upon his ascent of the Hudson with the Clermont in the fall of 1807 . This was both a scientific and an economic success-the forerunner of the keels which have cut the rivers and the fleets which have whitened the oceans for over 100 years. For this his name will be remembered through the ages.

He was born in Little Britain township (now Fulton) near Lancaster, Pa., November 14, 1765. His father, Robert, was a farmer in moderate circumstances, who died when his son was but 3 years old. His early schooling was in Lancaster under a Quaker by the name of Johnson, who thought him a dull scholar and not infrequently reproved him for his idleness. But he was busy outside, if not inside, the schoolroom. He frequented the shops, in which he was a favorite, and showed decided skill both in drawing and mechanics. Many stories are told of his youthful inventions and of the projects, some visionary and some practical, of which his head was full. He resolved to be an artist and at the age of 17 went to Philadelphia to study his profession, in which he at once showed talent, and was faithful and industrious in its pursuit. He painted a number 
of portraits and landscapes of more than ordinary merit, and made many friends during the next four years, among them Benjamin Franklin, who encouraged him in his work and doubtless talked with him about his own discoveries and inventions, possibly giving him a bent toward the vocation he afterward adopted. Another serviceable friend was Benjamin West, then at the hight of his reputation as an artist, with whom he frequently corresponded and upon whose advice he went to England in 1786. He was engaged in his profession in London for over 10 years, producing many excellent pictures, being well paid therefor, and receiving the constant counsel and good offices of West. During his residence in England, however, he became well acquainted with men of high scientific attainments, Sir John Sinclair, president of the Board of Agriculture, and the Duke of Bridgewater, the founder of the canal system of Great Britain, being among them. It is said that the latter named nobleman induced Fulton to abandon art and take to the study of mechanical science. He certainly was very active along the new line during the latter portion of his stay in England. He published a treatise on canal navigation, included in which were suggested improvements in bridges and aqueducts, and he built on the Shrewsbury canal at Long and across the river Dee in Scotland aqueducts upon his plan. So early as 1793 he conceived the idea of propelling vessels by steam. In 1794 he obtained a patent for a double-inclined plane for raising and lowering boats in canal locks, and also patents for several minor devices. About this time he sent copies of his work on canals to Governor George Clinton and Albert Gallatin, Secretary of the Treasury, accompanied by earnest arguments for the construction of canals in the United States; and it is claimed that in 1807 he made the first public appeal in behalf of a canal from Lake Erie to the Hudson. He was afterward one of the commission appointed to superintend the construction of the Erie canal.

Late in 1797 Fulton went to Paris, which was his principal place of residence until his return to his own country in 1806 . There he became intimate with Joel Barlow, afterward the United States Minister to France and the well known author of "Hasty Pudding," the "Columbiad" dedicated to Fulton, and other patriotic poems. They were mutually interested in poetry, painting and mechanics. There also he was brought into close relations with Robert $R$. Livingston, who, while chancellor of the New York Court of Chancery, administered the oath of office to President Washington, 


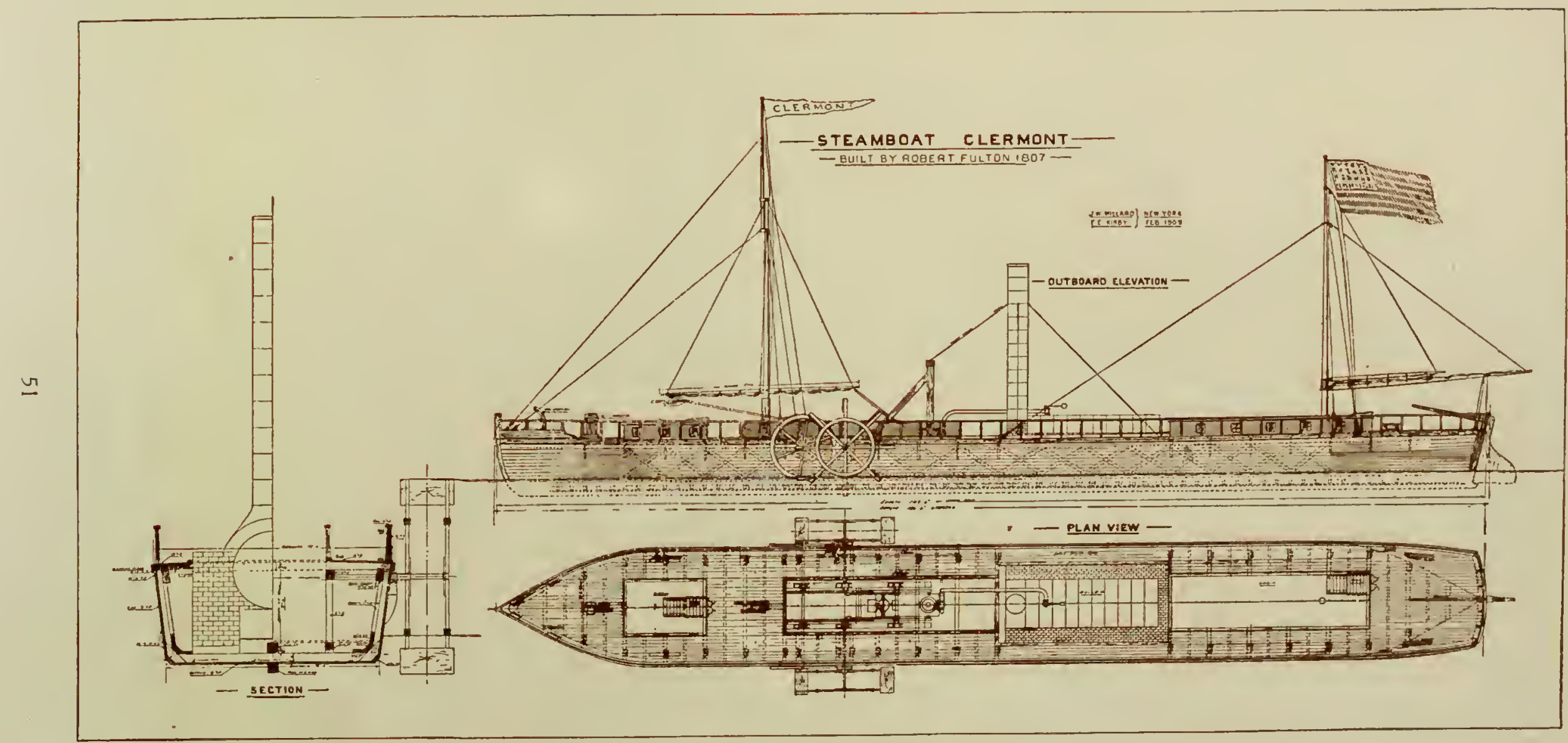

Plan of the Clermont reproduced by the Hudson-Fulton Celebration Commission 
and was Minister to France from 1801 till 1804. Livingston was a student in mechanics and science and was deeply interested in steam navigation. Many consultations between the two resulted in the building of an experimental boat, at their joint expense, in 1803 , which was successfully launched upon the Seine. She was 66 feet long and 8 feet wide and moved by wheels, but did not meet expectations as to speed. But Fulton and Livingston then and there determined to build a larger and more powerful vessel for the Hudson, and Livingston had already secured from the Legislature of New York exclusive privileges for the navigation by steam of the waters of the State. During his stay in France Fulton devoted much attention to experiments in submarine gun explosives and diving boats, his blowing up of the Dorothea in Walmar Roads near Deal, in 1805 in the presence of William Pitt, the English prime minister, being his most notable exhibition in this regard. He continued his experiments with torpedoes and his efforts to obtain governmental sanction for their use, and in 1813 took out a United States patent "for several improvements in the art of maritime warfare and means of injuring and destroying ships and vessels by igniting gunpowder under water"; but he does not seem materially to have profited by his inventions in submarine warfare. Its development was reserved until a later day than his.

Fulton returned to America in October 1806 to build his steamboat, and made his home thereafter in New York city. It would be pertinent to describe a few of the efforts made by others prior to Fulton's supreme success, but only a passing allusion may be indulged in. Some who tried came very near to winning the laurels which he bore away, but they just missed inventing the special devices or commanding the resources that brought him honor. The idea of steam navigation was in the air for many years and the list of those who sought to give it expression is a long one. As early as 1690 a German by the name of Papin published a work in which he proposed steam as a universal motive power, but the thought died with its utterance. In 1763 William Henry is said to have put a model steamboat on the Canastoga in Chester county, Pennsylvania. There follow the experiments of James Rumsey on the Potomac in 1784 and on the Thames in 1792; those of John Fitch on the Delaware in 1787 and on Collect pond, New York, in 1796. His boats were propelled by oars or paddles at the sides, and he is conceded to have come nearer to attaining success than any one 


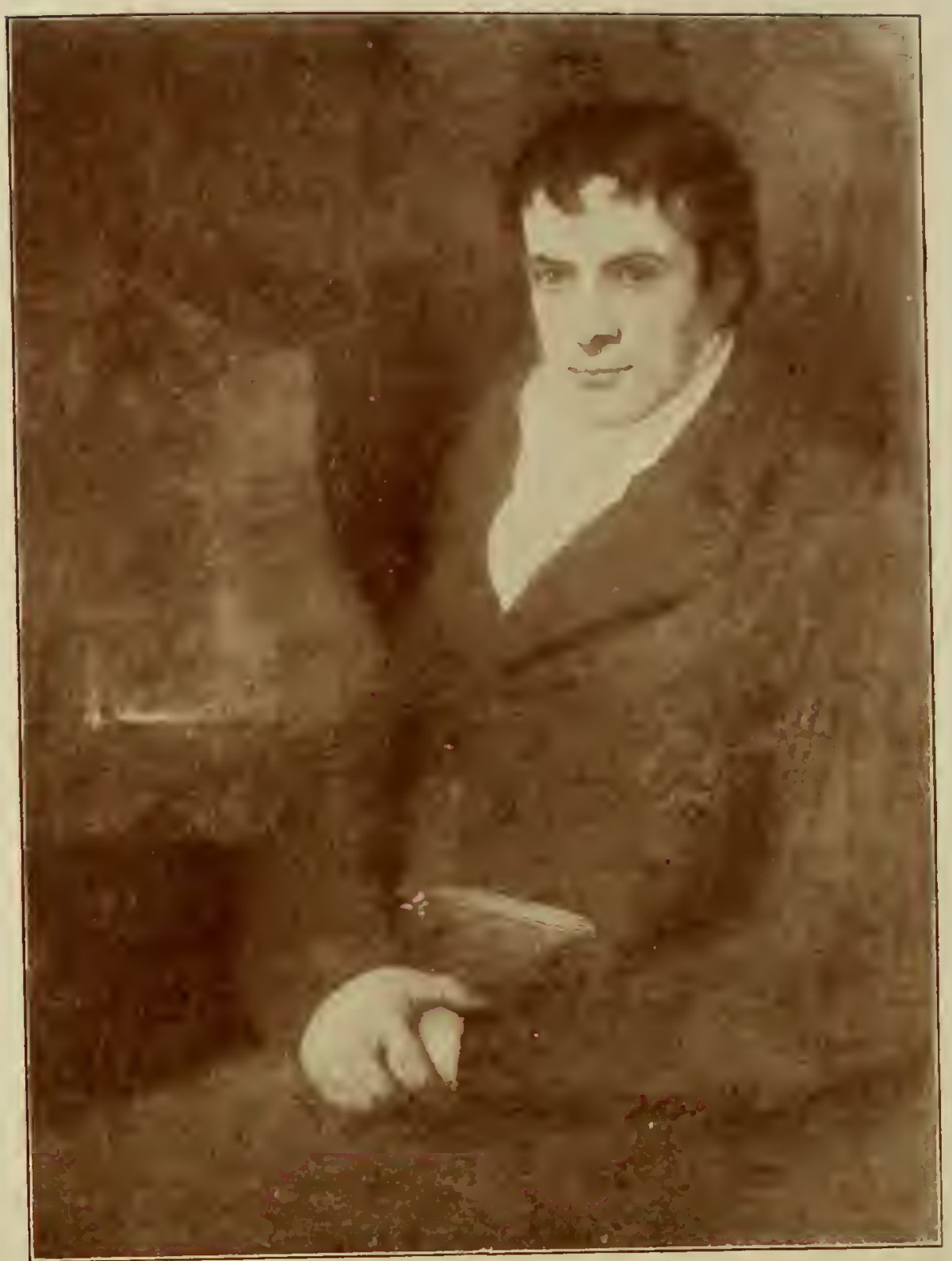

FROM PAINTING BY BENJAMIN WEST IN POSSESSION OF FULTON'S GRANDSON, MR ROBERT FULTON LUDLLOW OF CLAVERACK, N. Y

\section{Robert Fulton}

else before Fulton. Other attempts are those of Nathan Read at Danvers, Mass. in 1789; of Elijah Ormsbee at Providence in 1792; of Samuel Morey on the Connecticut between 1790 and 1794; and of Colonel John Stevens of Hoboken on the Hudson in 1804. It would require too many technical terms and occupy too much space to detail the points of these and other inventions, and in the comparison it is sufficient in defining the superiority of Fulton to quote the following from his biography by Reigart: "In none of those who have attempted this great object were united those qualities and acquirements to which Mr Fulton owed his success: that is to say, a genius for invention, mathematical and philosophical science, mechanical knowledge, and, what is rare in combination with these, considerable practice." 
Fulton's boat was built in the spring of 1807 and named the Clermont after the estate of Chancellor Livingston on the Hudson. She was 150 feet long, 13 feet wide and 7 feet deep, and measured 160 tons. The engine was 24 inches diameter of cylinder with 3 feet stroke. The boiler was of the low pressure pattern, 20 feet long, 7 feet deep and 8 feet broad. Her side wheels were 15 feet in diameter with buckets 4 feet wide dipping 2 feet into the water. She started on her first trip from New York to Albany on the 11th of August 1807 at 1 o'clock p. m. with Fulton, a few friends and mechanics, and six passengers on board, and with an incredulous and jeering crowd witnessing her departure. She was met by wondering spectators on the shores and on the crafts of the river throughout her passage, to many of whom she appeared as a monster breathing flames and smoke, for using only pine wood for fuel she sent high a column of ignited vapor, and sparks flew thick and fast. The trip is best described by Fulton himself in a letter to the "American Citizen," as follows:

To the Editor of the "American Citizen":

Sir: I arrived this afternoon, at four o'clock, in the steamboat from Albany. As the success of my experiment gives me great hopes that such boats may be rendered of great importance to my country, to prevent erroneous opinions and give some satisfaction to the friends of useful improvements, you will have the goodness to publish the following statement of facts:

I left New York on Monday at one o'clock and arrived at Clermont, the seat of Chancellor Livingston, at one o'clock; time, 24 hours, distance, 110 miles. On Wednesday I departed from the Chancellor's at nine in the morning, and arrived at Albany at five in the afternoon; distance, 40 miles, time, 8 hours. The sum is 150 miles in 32 hours, equal to near five miles an hour.

On Thursday, at nine o'clock in the morning, I left Albany, and arrived at the Chancellor's at six o' clock in the evening. I started from thence at seven and arrived at New York at four in the afternoon; time, 30 hours, space run through, 150 miles, equal to five miles an hour. Throughout my whole way, both going and returning, the wind was ahead; no advantage could be derived from my sails: the whole has, therefore, been performed by the power of the steam-engine.

I am, Sir, your obedient servant,

\section{ROBERT FULTON}

Thus modestly does its author announce one of the most stupendous events in human history. His words are golden now. In a subsequent letter to his friend, Barlow, he as modestly, as confidently, predicts some of the results of his undertaking. He says: 
Having employed much time, money and zeal in accomplishing this work, it gives me, as it will you, great pleasure to see it fully answered my expectations. It will give a quick and cheap conveyance to the merchandise on the Mississippi. Missouri, and other great rivers, which are now laying open their treasures to the enterprise of our country. men; and, although the prospect of personal emolument has been some inducement to me, yet I feel infinitely more pleasure in reflecting on the immense advantage my country will derive from the invention.

Eight years of life remained to Robert Fulton after his crowning triumph. They were years of incessant activity-of improving his great invention and conceiving new ones; of the building of many boats for the Hudson and of ferry boats for the East river; of infringements of his patent, which he was obliged to protect in the courts; of constant attacks upon his franchises; of uniawful competition and ceaseless vexation. He failed to secure due pecuniary returns for his enterprise, was harassed by litigation, and at the end he was insolvent. In his last year, when the United States was at war with Great Britain and New York was threatened by a hostile fleet, he built by direction of the government a steam war vessel-the first of its kind. It was named Fulton the First, and was launched on the East river October 29, 1814. Fulton died on the 23d of February 1815 at the age of 49 years. His death was attended by extraordinary demonstrations of public esteem. There were glowing eulogies and symbols of sorrow in the press; sermons and orations ${ }^{\prime}$ were pronounced in his honor; the corporation of the city, literary institutions and scientific societies paid tribute to his worth; the Legislature of the State wore mourning badges for one who, although never holding public office, had done more than any other citizen for the economic welfare of the State. And the funeral procession was remarkable for its numbers, its quality and its dignity, including representatives of the national, state and municipal governments, and of learned and civic associations. He was buried from Trinity Church on the 25th of February, and his body rests in its historic ground, in the vault of the Livingston family into which family he married. On the south wall of the church is the tablet to his memory placed there by the American Society of Mechanical Engineers in 1901. By it rushes the mighty, never-ebbing tide of the activities of Broadway, and not far distant is the majestic flow of the river upon which he ordained a revolution in navigation. 


\section{EXTRACT FROM ROBERT JUET'S LOG-BOOK ${ }^{1}$ \\ *}

$\mathrm{T}$

HE ffteenth, ${ }^{2}$ in the morning was misty, untill the sunne arose: then it cleered. So wee weighed with the wind at south, and ran up into the river twentie leagues, passing by high mountaines. Wee had a very good depth, as sixe, seven, eight, nine, ten, twelve, and thirteene fathomes, and great store of salmons in the river. This morning our two savages got out of a port and swam away. After wee were under sayle, they called to us in scorne. At night we came to other mountaines, which lie from the rivers side. . .

The sixteenth, faire and very hot weather. In the morning our boat went againe to fishing, but could catch but few, by reason their canoes had beene there all night. This morning the people came aboord, and brought us eares of Indian corne, and pompions, and tabacco: which wee bought for trifles. Wee rode still all day, and filled fresh water; at night wee weighed and went two leagues higher, and had shoald water: so wee anchored till day.

The seventeenth, faire sun-shining weather, and very hot. In the morning, as soone as the sun was up, we set sayle, and ran up sixe leagues higher, and found shoalds in the middle of the channell, and small ilands, but seven fathoms water on both sides. . .

The eighteenth, in the morning, was faire weather, and we rode still. In the after-noone our masters mate went on land with an o!d savage, a governor of the countrey, who carried him to his house, and made him good cheere. The nineteenth was faire and hot weather: at the floud, being neere eleven of the clocke, wee weighed, and ran higher up two leagues above the shoalds, and had no lesse water than five fathoms; wee anchored, and rode in eight fathomes.

The twentieth, in the morning was faire weather. Our masters mate with foure men more went up with our boat to sound the river, and found two leagues above us but two fathomes water, and the channell very narrow; and above that place, seven or eight fathomes. Toward night they returned: and we rode still all night. The one and twentieth was faire weather, and the wind all southerly: we determined yet once more to go farther up into the river, to trie what depth and breadth it did beare; but much people resorted aboord. . .

The two and twentieth was faire weather: in the morning our masters mate and foure more of the companie went up with our boat to sound the river higher up.

This night, at ten of the clocke, our boat returned in a showre of raine from sounding of the river; and found it to bee at an end for shipping to goe in.

1 Juet was a companion of Hudson on the Half Moon and kept his journal.

${ }^{2}$ September 15, 1609. It is supposed that the Half Moon came about as far north as the site of Albany and that the small boats reached the place where Waterford now stands. 


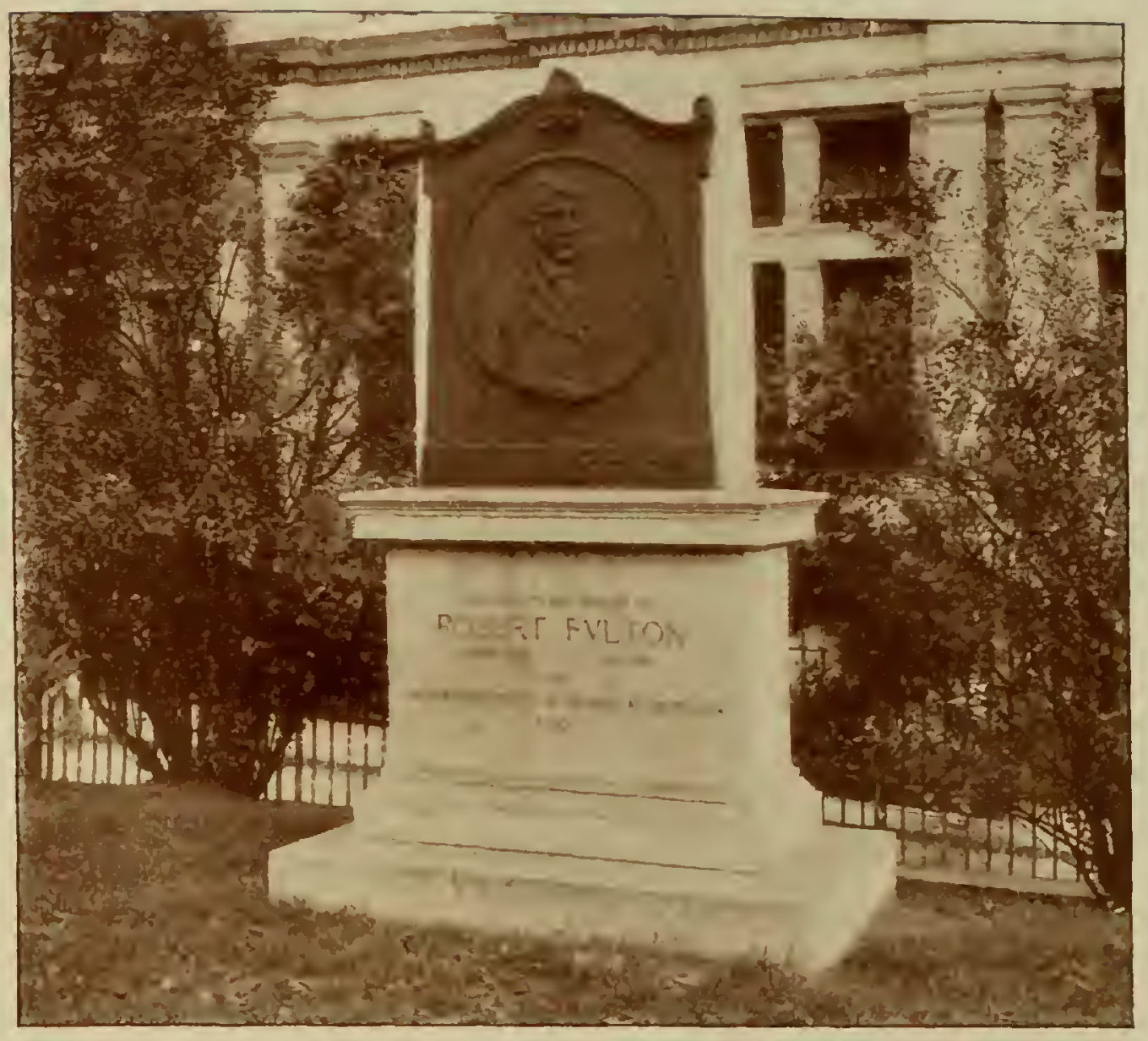

Fulton monument in Trinity churchyard

\section{THE GATES OF THE HUDSON}

\section{*}

O bright the day, so clear the sky,

So grand the scene before me

My meaner life my soul puts by,

And a better mood comes o'er me.

God built these hills in barrier long, And then he opened through them These gates of granite, barred so strong He only might undo them;

From under trees whose rustling leaves Wear all their autumn glory,

I watch the brown fields far below, And the headlands, gray and hoary.

Through them he lets the Hudson flow For slowly counted ages,

The while the nations fade and grow Around the granite ledges.

I see the beetling Palisades, Whose wrinkled brows forever,

In calms and storms, in lights and shades, Keep watch along the river.

Such watch, of old, the Magi kept Along the sad Euphrates:-

Our eyeless ones have never slept, And this their solemn fate is :

He bids these warders watch and wait, Their vigil ne'er forsaking,

Forever standing by the gate, Not moving and not speaking.

So, all earth's day, till night shall fall, When God shall send his orders,

And summon at one trumpet-call The grim and patient warders.

The guards shall bow, the gates shall close Upon the obedient river,

And then no more the Hudson flows,

Forever and forever.

William Osborn Stoddard 


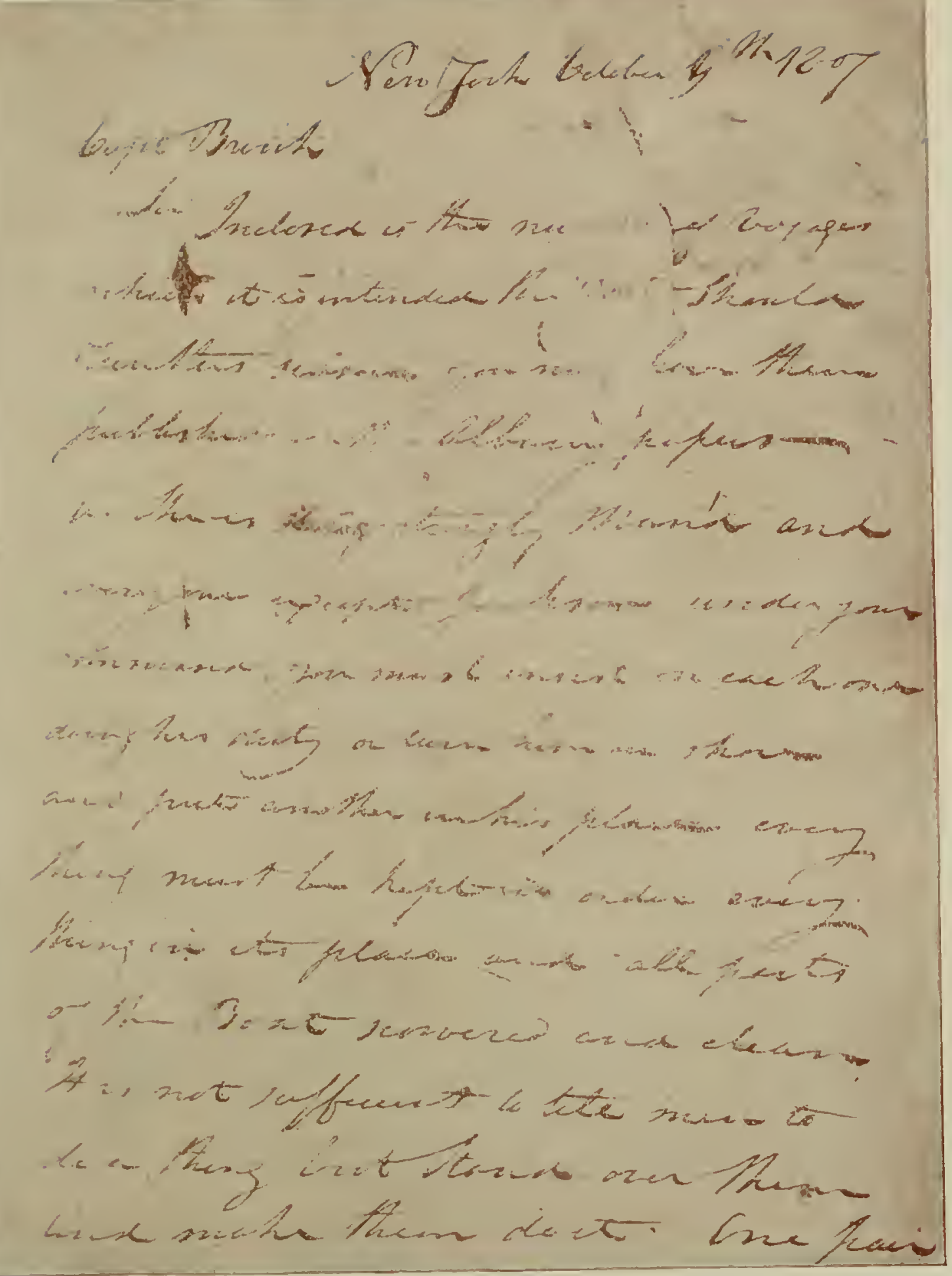

This Fulton letter in the possession of Mr Benj. Myer Brink, Kingston, N. Y. is reproduced through his courtesy.

\section{Captain Brink,}

Sir :

Inclosed is the number of voyages which is intended the Boat should run this season. You may have them published in the Albany papers.

As she is strongly manned and every one except Jackson under your command, you must insist on each one doing his duty or turn him on shore and put another in his place. Everything must be kept in order, everything in its place, and all parts of the Boat scoured and clean. It is not 


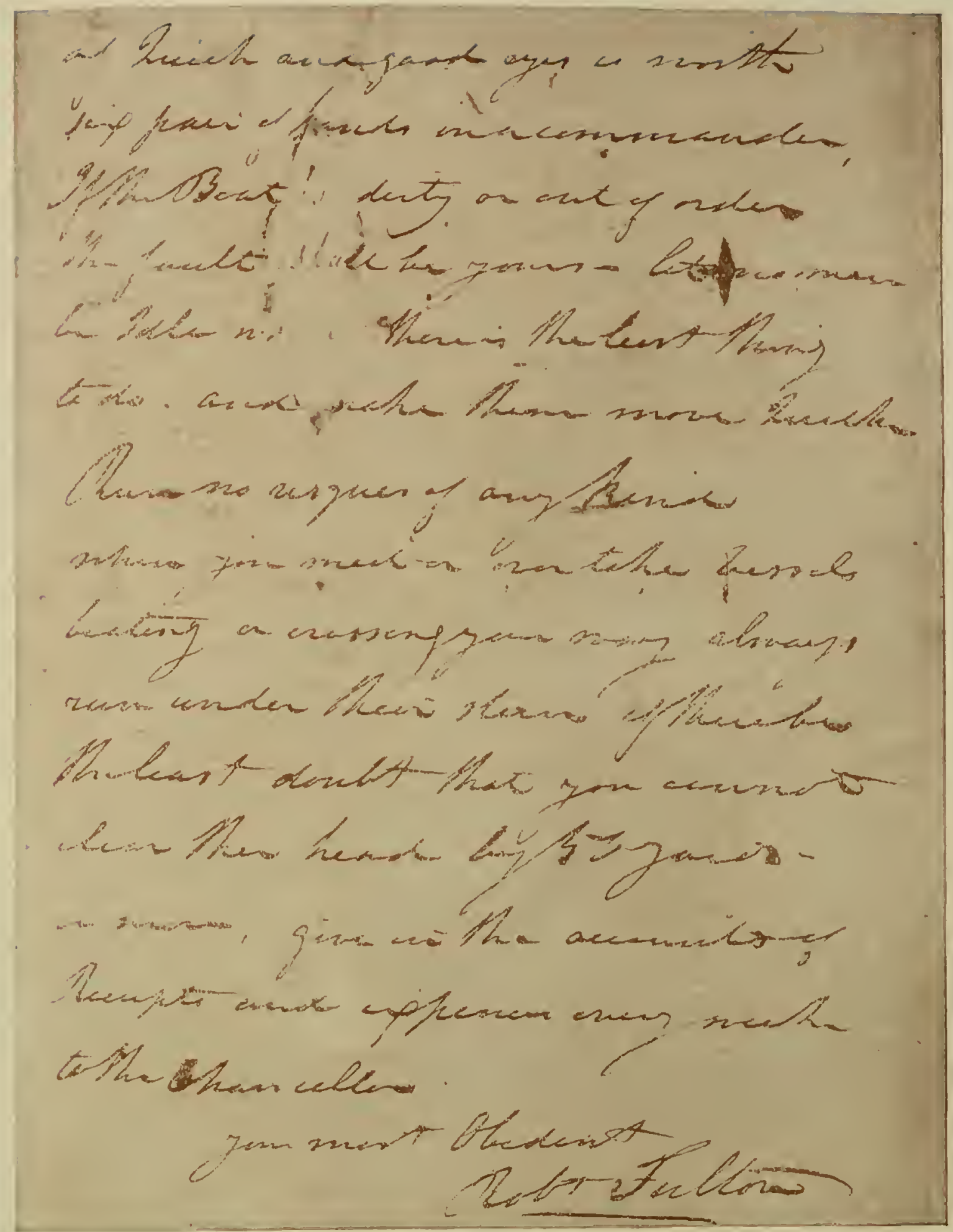

sufficient to tell men to do a thing but stand over them and make them do it. One pair of quick and good eyes is worth six pairs of hands in a commander. If the Boat is dirty or out of order, the fault shall be yours. Let no man be idle when there is the least thing to do, and make them move quick.

Run no risques of any kind when you meet or overtake vessels beating or crossing your way. Always run under their stern if there be the least doubt that you cannot clear their head by 50 yards or more. Give in the accounts of Receipts and expenses every week to the Chancellor.

Your most obedient,

ROBT. FULTON. 


\section{BIBLIOGRAPHY \\ Starred titles indicate material specially useful in school work.}

\section{Early voyages and discovery}

Bacon, E. M. English Voyages of Adventure and Discovery, Retold from Hakluyt. 401p. 1908. Scribner $\$ 1.50$.

De Costa, B. F. Explorations of the North American Coast Previous to the Voyage of Henry Hudson. (See Wilson, J. G. ed. Memorial History of the City of New York. 1892-93. 1:1-32)

*Discovery of America. Old South Work, Boston. 5c. (Old South Leaflets, no. 29)

*Fiske, John. Discovery of America. 2v. 1892. Houghton \$4.

*Johnson, W. H. The World's Discoverers ; the Story of Bold Voyages by Brave Navigators during a Thousand Years. 416p. 1908. Little $\$ 1.50$.

Murphy, H. C. Voyage of Verrazzano, a Chapter in the Early History of 'Maritime Discovery in America. $198 \mathrm{p} .1875$.

Payne, E. J. History of the New World Called America. 2v. 1892-99. Discovery and Early Voyages, v. 1. ch. 1.

*Verazzano, John de. Voyage along the Coast of North America from Carolina to Newfoundland, A. D. 1524, tr. fr. the original by J. G. Cogswell. (Sec New York Historical Society. Collections. ser. 2, 1:37-67; also Old South Leaflets, no. 17)

*Voyages of the Cabots. Old South Work, Boston. 5c. (Old South Leaflets, no. 37)

*Voyages to Vinland. Old South Work, Boston. 5c. (Old South Leaflets, no. 31)

Weise, A. J. Discoveries of America to the Year 1525. 380p. 1884. Putnam $\$ 4.50$.

*Winsor, Justin. Cartier to Frontenac; Geographical Discovery in the Interior of North America in its Historical Relations, 1534-1700. 379p. 1894 . Houghton $\$ 4$.

\section{Relations of England and Holland at the time}

Barker, J. E. Rise and Decline of the Netherlands. 478p. 1906. Dutton $\$ 3.50$ net.

The whole book is a comparison of the Netherlands and the British empire, and describes both their political and trade relations at this period.

*Fiske, John. Dutch and Quaker Colonies in America. 2v. 1900. Houghton $\$ 4$.

Discusses the relations of England and Holland at the time and previous to the settlement of New Netherland in v. 1, ch. 1, 2 and 9.

*Gardiner, S. R. Student's History of England. 1030p. New ed. 1904. Longmans $\$ 3.50$.

*Green, J. R. Short History of the English People. 782p. Revised ed. 1899. Harper $\$ 1.20$.

Motley, J. L. United Netherlands. 4v. 1898. Harper \$8.

From William the Silent to $1609 ; v$. 4 gives the conditions for this period.

*Traill, H. D. cd. Social England; v. 4, from the accession of James 1 to the death of Anne. 1897. Putnam $\$ 3.50$.

Contains chapter on exploration and colonization, p. 51-67; the whole volume excellent for a picture of conditions in England.

Van Pelt, Rev. Daniel. The Antecedents of New Netherland and the Dutch West India Company. (See Wilson, J. G. ed. Memorial History of the City of New York. 1:55-108. 


\section{Henry Hudson and the exploration of the Hudson river}

Asher, G. M. Henry Hudson, the Navigator. 218 +292p. 1860. (In Hakluyt Sociery Works. 1860, v. 27)

A collection of the chief original documents in which Hudson's career is recorded, parily translated and annotated, with an introduction and bibliography.

*Bacon, E. M. Henry Hudson: His Times and His Voyages. 277p. 1907. Purnam $\$ 1.35$ net.

Describes adventures during four voyages and estimates explorer's character and achievements. Based on contemporary documenis.

Bardsen, Ivar. Sailing Directions of Henry Hudson Prepared for his Use in 1608; from the old Danish, with an introduction, also a dissertation on the discovery of the Hudson river by B. F. De Costa. 102p. 1869.

Cleveland, H. R. Life of Henry Hudson. (See Sparks, Jared, $c d$. Library of American Biography. 1834-48. 10:185-261. Harper \$1.25)

*Gordy, W. F. Henry Hudson. (See Gordy, W. F. Stories of American Explorers. 1906, p. 142-53. Scribner 50c net)

*Griffis, W. E. Romance of Discovery. 304p. 1897. Wilde $\$ 1.50$.

*Higginson, T. W. Henry Hudson and the New Netherlands. (Sec Higginson, T. W. Book of American Explorers. 1907. p. 279-307. Longmans $\$ 1.20$ net) An authentic sketch of Hudson's life, particularly interesting to children. Illustrated.

*Janvier, T. A. Henry Hudson, Navigator. (Sec Cosmopolitan. Oct. 1903, p. 603; Nov. 1903, p. 90)

Two delighfful sketches written in view of the third centenary of Hudson's exploration of the Hudson river.

* Juet, Robert. Third Voyage of Master Henry Hudson. (See Asher, G. M. Henry Hudson, the Navigator. 1860. p. 45-92; also New York Historical Society. Collections. 1809. 1:102-46; also American Scenic and Historic Preservation Society Report. 1906)

Extract of Juet's journal in Old Sounh Leaflets, no. 94.

*Laut, Agnes C. Henry Hudson's First, Second, Third and Fourth Voyages. (See her Conquest of the Great Northwest. 1908. 1:3-72. Outing 2v. \$5)

Detailed, carefully written account based on aurhentic sources.

Murphy, H. C. Henry Hudson in Holland, an Inquiry into the Origin and Objects of the Voyage which Led to the Discovery of the Hudson River, with Bibliographical Notes. 72p. 1859.

*Parton, James. Captain Henry Hudson. (Sce Parton, James. Colonial Pioneers. 1890. p. 57-63. Maynard, paper, 12c)

Brief sketch for younger readers.

Purchas, Samuel. Hakluytus Posthumus; or, Purchase His Pilgrimes. Ed. $4.5 \mathrm{v}$. 1625-26.

Hudson's third voyage [Juet's journal] 3:581-95. The whole is the basis of Asher's "Henry Hudson, the Navigator."

Read, J. M. jr. Historical lnquiry Concerning Henry Hudson, his Friends, Relatives and Early Life, his Connection with the Muscovy Company and Discovery of Delaware Bay. 209 p. 1866.

The same, abridged and edited by Edmond Goldsmid. (See Clarendon Society. Reprints. 1882-84. ser. 1, p. 143.230

Wilson, J. G. Henry Hudson's Voyage and its Results in Trade and Colonization. (See Wilson, J. G. ed. Memorial History of the City of New York. 1892-93. 1:108-51; also in National Magazine, Jan. 1892, 15:221-49) 


\section{Indians}

* Fiske, John. Discovery of America, with Some Account of Ancient America. 2v. 1892. v. 1 , ch. 1 is a history and description of the Indians.

Megapolensis, Johannes. Short Sketch of the Mohawk Indians in New Netherland. . . written in the year 1644, revised with an introduction and notes by J. R. Brodhead. (New York Historical Society. Collections. 1857. ser. 2, 3:137-60)

Morgan, L. H. League of the Iroquois; new edition, annotated by H. M. Lloyd. 2v. in 1. 1904. Dodd $\$ 5$ net.

*New York (State) - Museum. Aboriginal Occupation of New York. 190p. 1900. (Museum bulletin 32)

* History of the New York lroquois. 340p. 1905. (Museum bulletin 78)

* - Myths and Legends of the New York State Iroquois, by H. M. Converse. 195p. 1908. (Museum bulletin 125)

Ruttenber, E. M. History of the Indian Tribes of the Hudson River. . . 415p. 1872.

Native Inhabitants of Manhattan and its Indian Antiquities. (Sce Wilson, J. G. cd. Memorial History of the City of New York. 1892. 1:33-55)

\section{Settlement of New Netherland}

\section{Sources}

*Donck, Adriaen Van der. Description of the New Netherlands. Ed. 2. 1656. (See New York Historical Society Collections. 1841. ser. 2, 1:129-242; sec also Old South Leaflets, no. 69)

*Hart, A. B. ed. American History Told by Contemporaries ; v. 1, 1492-1689. 1897. Macmillan $\$ 2$.

Source material of early explorations and the settlement of New Netherland.

Heckewelder, Rev. John. Indian Tradition of the First Arrival of the Dutch at Manhattan Island, now New York. (See New York Historical Society. Collections. 1841. ser. 2, 1:69-74)

* Jameson, J. F. ed. Narratives of New Netherland. Maps, facsim. O. 1909. Scribner $\$ 3$ net. (Original Narratives of Early American History, v. 9)

"About a score of narratives reproducing the most significant passages from the writings of contemporaneous historians touching the beginnings of New York city." Includes most of the entries given under this section - Sources.

Laet, John de. Extracts from the New World, or a Description of the West lndies, tr. from the original Dutch. (Sce New York Historical Society. Collections. 1841. ser. $2,1: 282-316)$

Melyn, Cornelis, anon. Broad Advice to the United Netherland Provinces, Made and Arranged from Divers True and Trusty Memoirs, by 1. A. G. W. C., tr. fr. the Dutch by H. C. Murphy. (See New York Historical Society. Collections. 1857. ser. 2 , 3:237-84)

New York Historical Society. Collections, 1809-59. 9v. New York 1811-59.

This series of volumes contains a great amount of important material on the early history of New Nether. land.

New York (State) - Legislature. Documents Relative to the Colonial History of the State of New York. 15v. Albany 1853-87.

v. 13 History and Settlements of the Towns along the Hudson and Mohawk Rivers; v. 12 Dutch and Swedish Settlements on the Delaware; v. 14 Early Colonial Settlements. Principally on Long Island.

New York (State) - Library. Van Rensselaer Bowier Manuscripts, Being the Letters of Kiliaen Van Rensselaer, 1630-1643, and Other Documents Relating to the Colony of Rensselaerswyck tr and ed. by A. J. F. van Laer. 909p. pl. map. O. Albany 1908. 
Vries, D. P. de. Voyages from Holland to America, A. D. 1632-1644, tr. fr. the Dutch by H. C. Murphy. (See New York Historical Society. Collections. 1857. ser. 2, $3: 1-136)$

Wassenaer, Nicolaes van. Description and First Settlement of New Netherland. (See O'Callaghan, E. B. ed. Documentary History of the State of New York. 1849. 51. $3: 25-63 ; 1850-51$, edition, 3:19-31)

\section{Later material}

Brodhead, J. R. History of the State of New York, 2v. 1853-71.

De Lancey, E. F. Origin and History of Manors in the Province of New York and in the County of Westchester. 160p. New York 1886. (Sce also Scharf, J. T. History of Westchester County. 1886. 1:31-160)

*Fiske, John. Dutch and Quaker Colonies in America. 2v. 1900. v. 1 Durch.

Hildreth, Richard. History of the United States of America. c1877. 1:136-49 and 413-45.

Covers New Netherland.

O'Callaghan, E. B. History of New Netherlands; or, New York Under the Dutch. 2 v. $1846-48$.

*Roberts, E. H. New York: the Planting and Growth of the Empire State. 2v. 1899. (American Commonwealth Ser.) Houghton $\$ 2.50$.

*Thwaites, R. G. The Colonies, 1492-1750. 301p. Ed. 3. 1897. Longmans \$1.25. (Epochs of American History)

\section{Hudson river}

*Bacon, E. M. The Hudson River, from Ocean to Source. 590p. 1907. Putnam $\$ 3.50$ net.

Treats of its history and legends from the Battery to Troy. Based on original records, some not hitherto published.

*Buckman, D. L. Old Steamboat Days on the Hudson River. 143p. 1907. Grafton Press $\$ 1.25$ net.

Tales and reminiscences of the stirring times that followed the introduction of steam navigation.

*Burroughs, John. Our River. (See Scribner, Aug. 1880, 20:481-93)

An illustrated sketch of the Hudson from a naturalist's point of view.

*Curtis, G. W. The Hudson and the Rhine. (Sce his Lotus-Eating. 1852. p. 11-27)

*Drake, J. R. The Culprit Fay. (See Warner's Library of the World's Best Literature. 3:4854-862 ; also Stedman, E. C. American Anthology, p. 42-45)

Hine, C. G. The West Bank of the Hudson River, Albany to Tappan: notes on its history and legends, its ghost stories and romances. Gathered by a wayfaring man who may now and then have erred therein. 174p. 1907. (Hine's Annual, 1906)

*Ingersoll, Ernest, comp. Rand, McNally \& Co.'s lllustrated Guide to the Hudson River and Catskill Mountains. Ed. 9. 1901. paper 25c.

Contains more than mere guidebook information.

*Irving, Washington. Dolph Heyliger. (See Bracebridge Hall. Author's revised ed. 1849. p. $395-469$ )

Legend of the storm ship is included in "Dolph Heyliger."

* The Legend of Sleepy Hollow. (See lus Sketch Book. Student's ed. p. 474)

* Rip Van Winkle. (See his Sketch Book. Student's ed. p. 50) 
*Longfellow, H. W. comp. Hudson River. (See his Poems of Places: America. Middle States. 1879. p. 97-113. Houghton \$1)

Lossing, B. J. The Hudson from the Wilderness to the Sea. 464p. 1866. Virtue $\$ 2.70$.

*Skinner, C. M. The Hudson and its Hills. (See his Myths and Legends of Our Own Land. Ed. 8. 1896. 1:17-107. Lippincott, 2v. \$3)

*Ver Planck, W. E. \& Collyer, M. W. The Sloops of the Hudson. 17/p. 1908. Putnam $\$ 1.50$ net.

"An historical sketch of the packet and market sloops of the last century . . . together with personal reminiscences of . . notable North river sailing masters."

\section{Steam navigation}

*Abbot, W. J. American Merchant Ships and Sailors. 372p. $1902 . \quad$ Dodd $\$ 2$ net.

Bullock, C. S. The Anniversary of American Commerce, 1807-1907: (See Journal of American History, 1907. v. 1, no. 3, p. 395-433)

Fry, Henry. (The) History of North Atlantic Steam Navigation, with Some Account of Early Ships and Ship Owners. 324p. 1896. Scribner $\$ 2.50$.

*Livingston, Robert. Invention of the Steamboat. 16p. 1812. (Old South Leaflets, no. 108) Old South Work, Boston. 5c.

*Mowry, W. A. American Inventions and Inventors. 298p. 1900. Silver 65c net. Ch. 4 and 5 sketch the history of the Clermont. Written for children.

Preble, G. H. A Chronological History of the Origin and Development of Steam Navigation, 1543-1882. 483p. 1883.

* Routledge, Robert. Steam Navigation and American Steamboats. (See his Discoveries and Inventions of the 19th Century, 1900. p. 129-48) Routledge $\$ 2.50$.

Woodcroft, Bennet. Sketch of the Origin and Progress of Steam Navigation. 140p. 1848.

\section{Robert Fulton}

Colden, C. D. Life of Fulton. 371p. 1817.

Fulton Memorial Number of the Journal of American History. 1907. v. 1, no. 3. July, Aug., Sept.

*Hale, E. E. Robert Fulton. (See Stories of Invention. 1900. p. 172-92. Little \$1) Excellent brief sketch for younger readers.

*Hubert, P. G. jr. Robert Fulton. (See Inventors. 1898. p. 45-68. Scribner \$1.50)

*Knox, T. W. Life of Robert Fulton and a History of Steam Navigation. 507p. 1896. (Boys' and Girls' Library of American Biog. v. 1) Putnam \$1.75.

Brief life of Fulton and a nontechnical account of the development of steam navigation.

*Miller, P. F. Story of Robert Fulton. 113p. 1908. Knickerbocker Press \$1.

Written from some new material.

*Morrison, J. H. Robert Fulton and the Side-wheel Steamer. (See Scientific American Sup. Mar. 2, 1907, 64:282)

Reigart, J. F. Life of Fulton. 297p. 1856.

Renwick, James. Life of Robert Fulton. (See Sparks, Jared, ed. Library of American Biography. 1834-48, 10:1-89)

Sutcliffe, A. C. Early Life of Robert Fulton. (See Century, Sept. 1908, 76:780-94)

*Thurston, R. H. Robert Fulton, his Life and its Results. 194p. 1891. Dodd 75c.

A short biography, with a sketch of the developmen of the steam engine and steam navigation. 



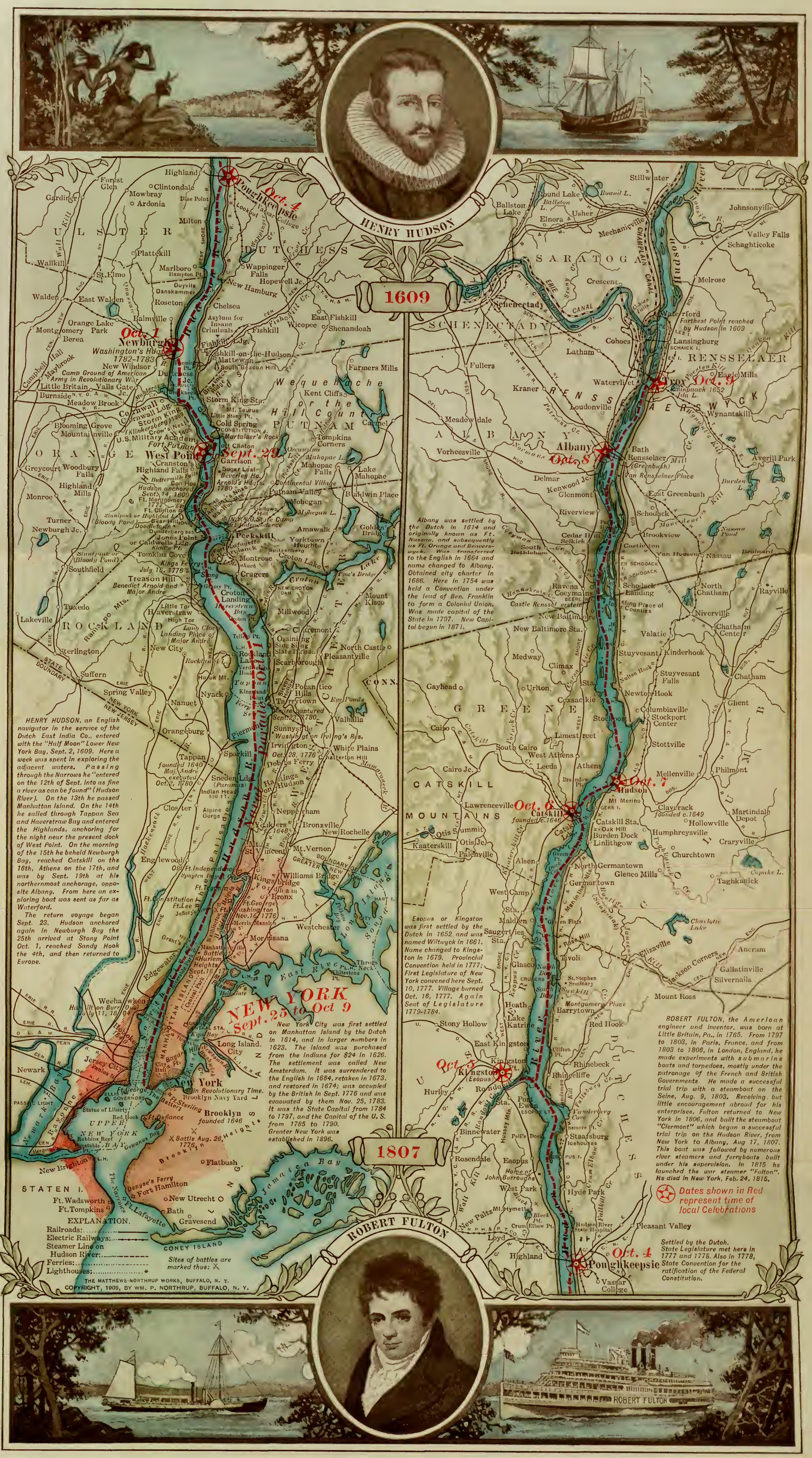




